\title{
Violencias en contexto
}

$\omega$

O

으

5

는

ర

()

-

느

(1)

()

No. 2

\section{Javier Guerrero Barón Bárbara Yadira García Sánchez}






\title{
Violencias en contexto
}

\author{
La ciudad, el barrio \\ y la violencia escolar
}

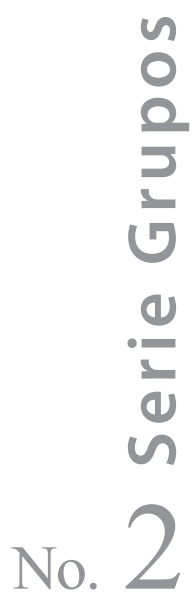

Javier Guerrero Barón

Bárbara Yadira García Sánchez

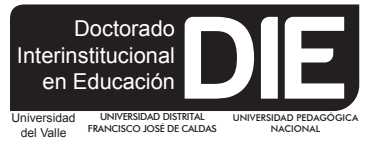




\section{UNIVERSIDAD DISTRITAL FRANCISCO JOSÉ DE CALDAS}

Rector

Inocencio Bahamon Calderon

Vicerrectoría Académica

María Elvira Rodríguez Luna

Vicerrectoría Administrativa y Financiera

Álvaro León Rojas

Sección Publicaciones - Jefe

Rubén Eliecer Carvajalino Carvajalino

COMITÉ EDITORIAL - CADE

Presidenta CADE

Adela Molina Andrade

Representante grupos de investigación Interculturalidad, Ciencia y Tecnología INTERCITEC, y del Grupo Didáctica de la Química - DIDAQUIM. Del énfasis de Educación en Ciencias.

\section{Álvaro García Martínez}

Representante de los grupos de investigación Identidad, Lenguaje y Cultura, Moralia, Estudios del Discurso, Educación Comunicación y Cultura del énfasis de Lenguaje y Educación.

\section{Sandra Soler Castillo}

Representante de los grupos de investigación: Interdisciplinaria en Pedagogía de Lenguaje y las Matemáticas GIIPLyM Matemáticas Escolares Universidad Distrital - MESCUD , del énfasis de Educación Matemática.

Olga Lucia León Corredor
Representante de los grupos de investigación Formación de Educadores, del énfasis de Historia de la Educación, Pedagogía y Educación Comparada.

\section{Rigoberto Castillo}

Representante de los estudiantes -se elige el 16 de Mayo de 2012 por votación virtual.

José Javier Betancourt Godoy

COMITÉ EDITORIAL INTERINSTITUCIONAL - CAIDE

Directora Nacional

Margie Nohemy Jessup C.

Coordinadora DIE -Universidad

Pedagógica Nacional

Rosalba Pulido de Castellanos

Coordinadora DIE - Universidad Distrital Francisco José de Caldas

\section{Adela Molina Andrade}

Coordinador DIE - Universidad del Valle Eric Rodríguez Woroniuc

(c) Universidad Distrital Francisco José de Caldas

ISBN: 978-958-8782-05-8

e-ISBN: 978-958-8782-96-6

Primera edición, 2012

Diseño, Diagramación e impresión

Fundación Común Presencia

Prohibida la reproducción total o parcial sin permiso escrito de la Universidad Distrital Francisco José de Caldas.

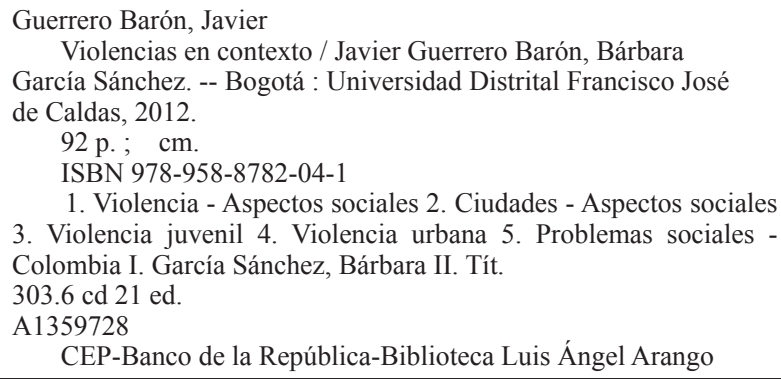


$\begin{array}{ll}\text { Agradecimientos } & 7\end{array}$

Presentación 9

Para pensar la violencia:

elementos conceptuales y epistemológicos 13

El triángulo de Galtung $\quad 15$

Las violencias micro y macro-sociales $\quad 18$

Las violencias juveniles $\quad 22$

El debilitamiento del concepto de autoridad 23

La autonomización de las mujeres y los jóvenes 24

Inserción juvenil en el mundo de la incertidumbre 26

La nueva miseria urbana $\quad 28$

Juventud, Violencia, Modernidad y Sociedad Civil 30

Incivilidad, pasado y futuro 34

La violencia ¿anomia o problema ético? 36

La ciudad latinoamericana:

economía, sociedad y juventud $\quad 41$

América Latina: estructuras que facilitan lo violento 42

Exclusión, pobreza, discriminación e informalidad 42

Actores residuales de las guerras $\quad 43$

Corrupción, mafias y permeabilidad ilegal $\quad 44$

Impunidad e inseguridad 47

La coyuntura y la crisis mundial: América Latina en alto riesgo social $\quad 48$

Sobre violencia urbana $\quad 55$

La ciudad, utopía y anti-utopía $\quad 58$ 
Sobre la ciudad globalizada y posmoderna $\quad 59$

¿Cuáles son las consecuencias de este crecimiento urbano? 60

La pobreza en Bogotá $\quad 62$

El desplazamiento en Bogotá 66

$\begin{array}{ll}\text { Las políticas de vivienda y el surgimiento del barrio obrero } & 67\end{array}$

$\begin{array}{ll}\text { El barrio urbano-popular } & 71\end{array}$

El barrio como espacio de socialización $\quad 75$

El barrio y la violencia urbana $\quad 78$

Infancia juventud y escuela: entre la informalidad y la ilegalidad $\quad 79$

Conclusiones: Escuela, barrio y riesgo social 83

$\begin{array}{ll}\text { Bibliografía } & 87\end{array}$

Índice de Cuadros

Cuadro 1. Colombia: Tasa de desempleo $\quad 49$

\section{Índice de figuras}

Figura 1. El triángulo de Galtung $\quad 15$

Figura 2. El triángulo de Galtung modificado 16

Figura 3. Campos de violencia $\quad 20$

Figura 4. Diferencia entre violencias micro y macro-social 20

Figura 5. Violencias juveniles: puente entre los campos de las violencias 23

Figura 6. Violencia Intrafamiliar en Colombia 52

Figura 7. Desmovilizados de los grupos ilegales en Colombia 57

Figura 8. Porcentaje de personas en pobreza y miseria en Bogotá 63

Figura 9. Hurto con y sin violencia y vandalismo en entornos escolares 81

Figura 10. El hurto en Bogotá 
Muchas son las personas e instituciones que colaboraron en el proceso de dos años y medio de investigación-acción. Algunas merecen mención y agradecimiento especial:

A las entidades que financiaron esta investigación titulada La violencia escolar en Bogotá: una mirada desde los maestros, las familias y los jóvenes. Aplicación de un modelo cualitativo de investigación y prevención en escuela, familia y barrio: A Colciencias, a la Universidad Distrital Francisco José de Caldas y a la Universidad Pedagógica y Tecnológica de Colombia. Al Doctorado Interinstitucional en Educación de la Universidad Distrital y al Doctorado en Historia de la Universidad Pedagógica y Tecnológica de Colombia. A los grupos de investigación Formación de Educadores y Conflictos Sociales Siglo XX.

A Catherine Blaya-Debarbieux, Doctora en Ciencias Sociales, profesora del Departamento de Ciencias de la Educación de la Universidad de Bourgogne y co-fundadora y miembro del Observatorio Europeo de la Violencia Escolar, ahora denominado Observatorio Internacional de la Violencia Escolar, quien asesoró esta investigación y además participó en numerosos eventos que se realizaron en el marco del proyecto, como las jornadas pedagógicas en Bogotá y las Jornada Internacional sobre Violencia Escolar realizada en la UPTC en Tunja, así como el desarrollo de un seminario y algunas conferencias.

A María Isabel Bernal Ardila, Marisol Cruz Ramírez e Ingrid Carolina Pabón Suárez, asistentes de investigación, quienes colaboraron transcribiendo, catalogando y sistematizando información de fuentes primarias, secundarias y de archivos institucionales de las Comisarías de Familia a través de fichajes y de la construcción y administración de las bases de datos, apoyo en la realización de entrevistas, grupos focales y NES con padres y madres de familia, docentes y líderes barriales y apoyo en la realización de eventos académicos propios del proyecto, entre otras actividades.

A Carmen Beatriz Torres Castro y Luz Stella Cañón Cueca, estudiantes del Doctorado Interinstitucional en Educación de la Universidad Distrital, quienes 
realizaron el trabajo de campo de sus tesis doctorales en el marco de esta investigación sobre violencia escolar femenina y la asociada a las barras del fútbol, a Jaime Mauricio Gutiérrez y Luz Nelly Novoa Vargas, estudiantes del Doctorado en Ciencias de la Educación de RudEColombia, CADE Tunja, quienes acompañaron el trabajo de campo y participaron en las sesiones de reflexión y evaluación de la información obtenida en cada uno de los escenarios investigados.

A la Doctora Adela Molina Andrade, Directora del Doctorado Interinstitucional en Educación de la Universidad Distrital Francisco José de Caldas y al CADE DIE-UD, por el apoyo para la publicación de los cuatro libros resultantes de la investigación.

A los autores de esta colección que hoy presentamos: Violencias en contexto: la ciudad, el barrio y la violencia escolar; Núcleos de Educación Social NES, Investigación, prevención y participación con metodología IAP; La violencia escolar en Bogotá desde la mirada de las familias y Los maestros ante la violencia escolar.

Gracias también a los directivos(as) docentes, a los maestros(as), a los padres y madres de familia, a los y las adolescentes, a los y las lideres barriales de las instituciones educativas de las localidades de Usaquén, Suba, Fontibón, Usme y Santa Fe, que nos hicieron sus confidentes y compartieron con nosotros experiencias, percepciones, vivencias y miedos relacionados con situaciones de violencia.

Pero sobre todo a los jóvenes del siglo XXI por llenarnos de esperanza en medio de la incertidumbre. 
"Al parecer, la dignidad de la vida humana no estaba prevista en el plan de globalización"

Ernesto Sábato (Antes del fin, 1999).

Esta es la primera parte de los resultados del estudio titulado La violencia escolar en Bogotá: Una mirada desde los maestros, las familias y los jóvenes en el que pretendemos sistematizar la experiencia investigativa realizada implementado un modelo cualitativo apoyado en la Investigación-acción-participativa, IAP, para prevenir violencias en la familia, la escuela y el barrio, mediante la aplicación del modelo Núcleos de Educación Social'1.

En este libro se pretende contextualizar la violencia escolar y sus principales manifestaciones en el "afuera" de la escuela, en su entorno barrial-urbano, en el contexto en general de la sociedad globalizada y de América Latina y, claro está, de Colombia, sin dejar de ser un estudio de caso de Bogotá.

Por eso, la primera precisión, reiteramos, es que nuestro estudio es una investigación empírica de casos en la ciudad de Bogotá, pero en contexto latinoamericano, y esa particularidad queremos resaltarla pues muchos de los estudios y metodologías de intervención y prevención a que se hace referencia en el campo de la violencia escolar provienen de conceptualizaciones de las sociedades, comunidades y familias europeas y norteamericanas. Es el contexto de sociedades distintas. Y esas particularidades pueden exigir matices en la reflexión, aunque las reflexiones conceptuales y teóricas no dejen de tener pretensiones universales. Por lo tanto, aunque tenemos bases de datos empíricas de nuestro trabajo de campo, de los estados del arte, de las diferentes categorizaciones y conclusiones de muchos tipos de investigaciones y reflexiones que sobrepasan los 17.000 registros, permanentemente tendremos que movernos en reflexiones en tres niveles: generales, de alcance intermedio y a datos empíricos de los casos investigados.

1. Ver, dentro de esta misma colección: García, Bárbara y Guerrero, Javier. Núcleos de Investigación Social - NES, Investigación, prevención y participación. (Con Metodología IAP). Bogotá, Universidad Distrital "Francisco José de Caldas", 2012. 
Para la primera parte queremos dejar claro un punto de partida que será transversal a todo el estudio: Hacer una reflexión general del contexto de las violencias, tema sobre el cual muchas veces se incurre en concepciones equívocas y en ingenuidades. Se trata de un campo de fenómenos amplio y complejo, sobre el cual muchas personas opinan, muchas veces sin la asertividad necesaria. Reflexionaremos sobre los conceptos básicos que sobre violencia trabajamos en diferentes textos y desde diferentes formas de conceptualización para que en un diálogo con cualquier lector, podamos poner en claro desde donde hablamos.

La principal y más importante precisión es muy sencilla: es partir de que "la violencia" es una forma de relación social. No es una cosa ni un sujeto con vida propia. El sustantivo "la violencia" no es un sujeto que le hace daño a la gente. En Colombia el término "La Violencia" es una época de nuestra historia, y es más, es un referente popular el antes o después de la Violencia. Algunos estudios han precisado este fenómeno:

[...] La Violencia vivencialmente constituía para aquellos habitantes, de todas las capas sociales, un gran sujeto personificado, activo, creador de acontecimientos -dolorosos- en síntesis, devastador. La Violencia nos mató un hermano, nos mató al padre', La Violencia nos quemó la casa, nos quitó la tierra, La Violencia nos sacó del campo, Mi esposa tuvo un hijo anormal debido a la Violencia y eso la llevó a la locura y al suicidio, por la Violencia (Ortiz, 1985: 22) ${ }^{2}$

El adjetivo "violento" con frecuencia se le adjudica a muchos sujetos, hombres, mujeres, naciones, sociedades, poblaciones, pero en estricto sentido es aplicable ante todo a relaciones y a situaciones. Los sujetos no "son violentos", ni hay una "esencia" violenta de los seres humanos, ni "históricamente" la humanidad ha sido violenta. Partimos de que hay seres humanos que en determinadas circunstancias se comportan violentamente. Tienen (o tenemos) conductas violentas, viven y vivimos situaciones relacionales de violencia. $Y$ esas condiciones pueden ser de diferente duración. Igualmente, hay sociedades, naciones, comunidades que han entrado en situaciones de violencia, que en determinadas condiciones pueden cesar. Desde este punto de vista no existe como tal, sino en ciertos estereotipos, una "escuela violenta".

2. El libro de Carlos Miguel Ortiz Estado y subversión en Colombia: La violencia en el Quindío en los años 50 es una de las obras relevantes en el análisis de esta situación crucial colombiana. Existe también un análisis pionero sobre el tema en un temprano y magistral ensayo de Laura Restrepo: "Niveles de realidad en la literatura de la violencia colombiana", donde el lector podrá profundizar su reflexión sobre este difícil panorama histórico (Restrepo, 1985: 117-169). 
Desde hace algunos años nuestro equipo de trabajo viene reflexionando sobre el tema de las violencias, por ello esperamos que este estudio, sea un aporte al debate de las distinciones entre las violencias macro-sociales y las violencias micro-sociales, sus multi causalidades, interconexiones, lógicas y racionalidades. No pretendemos hacer un tratado teórico sino dar un contexto conceptual el cual entregamos inicialmente en cuatro libros complementarios dentro de la Colección "Núcleos de Educación Social NES", pero que esperamos poder continuar con resultados de investigaciones y nuevas reflexiones sobre estas temáticas y modalidades de investigación social.

Reflexionar sobre la familia, la escuela, el barrio y la ciudad como escenarios de formación de sujetos, asumir a la escuela y al barrio como unidad de trabajo comunitario y a la familia como espacio fundamental (fundador) de lo humano es nuestra estrategia.

Esta es una reflexión que se ha tejido en conversaciones con pequeños grupos que llamamos "núcleos" de personas interesadas, afectadas o preocupadas, por situaciones de violencia. Los hallazgos han sido analizados en varios niveles: con las personas que participan, con los equipos de trabajo académico y con expertos nacionales e internacionales que trabajan el tema en dimensiones comparadas. Por lo tanto los lenguajes y niveles en los que trabajamos son "multifuncionales", como la polisemia de muchos de los conceptos y problemas que abordamos.

Nuestro espacio y objeto de trabajo es inmediato y a corto plazo. Es el trabajo en pequeños grupos allí donde la voluntad, el deseo y los objetivos de la sociedad civil son posibles a escala humana. Creemos que las violencias micro-sociales son las que más frecuentemente invaden el campo de la incivilidad y contribuyen a despertar la atrocidad y la crueldad latentes en muchos seres humanos y es en estos espacios donde paradójicamente mejor podemos actuar los educadores, los padres de familia, los líderes barriales.

Nuestro propósito es crear métodos que permitan "intervenir" preventivamente las pequeñas violencias, es decir, las que están cercanas a nosotros. Las otras, las violencias macro-sociales, las de las estructuras duras de las organizaciones armadas ilegales, la criminalidad organizada, e incluso la de los actores estatales, se salen de los métodos comunitarios. Tenemos, como ciudadanos, la obligación de conocerlas y de entender las dinámicas de dichas acciones. Sin embargo, es necesario aclarar que no es en los escenarios barriales, familiares o escolares donde se definen estos conflictos. 
Es un estudio de las pequeñas cosas, de experimentar cómo pensar-deciractuar como sujeto, como ciudadano/a, como maestro/a, como padre o madre de familia, como habitante de un barrio, como miembro de una comunidad y por qué no, como "ciudadano/a de la ciudad". (Lo que no nos quita serlo del país o del planeta).

Por eso nuestro estudio no pretende fundar teóricamente sino fundamentar (dar fundamento). Pretende trabajar teorías que sirvan de instrumento para comprender mejor y para no simplificar la realidad, pero sí para transformar desde lo pequeño.

En el caso de Bogotá, además de estos referentes espaciales de lo urbano y lo barrial, tenemos que tener en cuenta la unidad territorial y administrativa conocida como localidad 3 , barrio y las diferentes "zonas" territoriales que el lenguaje introduce, tales como cuadra, manzana o vecindario que son expresiones de lo urbano o de lo urbanístico, pero que para nosotros son unidades sociales o comunitarias de análisis.

Finalmente, no sobra recordar los tres principios básicos que han iluminado nuestro trabajo práctico con las comunidades: el primero: "creer en la grandeza de lo pequeño"; segundo "cambiar por dentro y transformar el resto" y tercero "conocer-actuar-transformar y resignificar las relaciones de la vida cotidiana".

3. La unidad administrativa denominada como "localidad" es equivalente en otras ciudades a la comuna o en el caso del Distrito Federal mexicano, a las Delegaciones. En general tiene varias denominaciones pero hace referencia a la comunidad local al interior de la metrópoli o gran ciudad. 


\section{Para pensar la violencia: elementos conceptuales y epistemológicos}

Nunca antes el concepto de violencia había estado en el centro de tantos debates de toda índole. Abordar este concepto tan usado y polisémico, y sobre el cual se han escrito verdaderos tratados, no es fácil. En primer lugar, algunas reflexiones fundamentales:

1. La violencia es ante todo acción humana. La primera idea que surge de ella es que se trata de una acción humana por la cual se establece una relación social, una forma de vínculo entre los individuos.

2. Otra idea importante que emerge es la idea de "exceso". Una acción es excesiva relativamente a su contexto, que tiene dos dimensiones: lo social y lo psicológico.

3. Inicialmente el concepto latino (violenta) hace énfasis en el uso de la fuerza física contra una persona.

El concepto tal y como hoy lo conocemos aparece en tratados normativos ingleses a finales de la Edad Media con tres significaciones: la más usual, uso de la fuerza física contra alguien; "interrumpir o molestar", "estorbar con rudeza y malos modos" o cuando se "profana, deshonra o ultraja"; como se analiza en el libro Reflexiones sobre la violencia (Keane, 2000: 61).

A medida que las relaciones sociales se han ido complejizando y la humanidad elevando sus niveles de conciencia frente al fenómeno, la definición y sus acepciones cobran nuevos sentidos.

La palabra puede tener hoy muchos significados. Para simplificar las posibilidades, vamos a fundar nuestras reflexiones en una de las más usuales conceptualizaciones, la del Informe mundial de violencia y de la salud, de la OMS que la define como con una pequeña modificación aclaratoria: 
[...] El uso intencional [o no $]^{4}$ de la fuerza o el poder físico, de hecho o como amenaza, contra uno mismo, otra persona o un grupo o comunidad, que cause o tenga muchas probabilidades de causar lesiones, muerte, daños psicológicos, trastornos del desarrollo o privaciones. (OMS, 2003: 5)

Dicha organización ha mostrado importante interés en el tema. En 1996, la Asamblea Mundial de la Salud, declaró a la violencia como un importante problema de salud pública y pidió a la OMS elaborar una tipología de la violencia. Como resultado de ello, se produjo una taxonomía de tipos de violencia que puede ser aplicable a este estudio. Es así como la violencia es clasificada en tres tipos: autoinfligida, interpersonal y colectiva. La autoinfligida, clasificada en comportamiento suicida y las autolesiones. La interpersonal comprende la intrafamiliar o de pareja y la comunitaria y la colectiva; finalmente la llamada violencia colectiva con las categorías social, política y económica.

Esta última tipología es una de las más usadas en los recientes estudios y se podría anotar críticamente que incurre en algunos lugares comunes, puramente funcionales y descriptivos, de tal forma que no da cuenta de algunas complejidades. Por ejemplo, en el caso de la violencia intrafamiliar se habla de violencias por grupos de edad: contra menores, de pareja y ancianos, tipología que no dice nada de la naturaleza del fenómeno. Por ejemplo, las Comisarías de Familia y las escuelas registran cada vez más frecuentemente casos de agresiones de menores contra maestros, padres y madres y cuidadores. Muchas tipologías suponen a niños, niñas y jóvenes siempre en el rol de víctima. Es indudable que las violencias femeninas hoy son más visibles y llamativas, lo que hace que la variable género es cada vez más relevante. Existen además violencias específicas contra la mujer. No obstante, legislaciones e impartidores de justicia muchas veces suponen que las mujeres siempre estarán en el lugar de la víctima a pesar de que las estadísticas y la casuística la colocan con mucha frecuencia en el lugar de victimaria. La tipología, como hemos dicho tiene vacíos, también hay un vacío al no tratar de establecer esas "direccionalidades" de las violencias, sin embargo la recopilación de cifras y estadísticas se basa en esta conceptualización.

Finalmente, vale la pena señalar que en esta tipología no hay lugar explícitamente para localizar las violencias institucionales, aunque se podría decir que están contempladas en las violencias colectivas de tipo político.

4. Consideramos que una acción puede ser violenta aún sin intención. Por eso introdujimos el modificatorio [o no] en la definición original. 
Por esa razón en nuestras investigaciones empíricas hemos encontrado que las "lógicas" que dan origen a estas acciones y relaciones violentas se pueden establecer en dos grandes campos que desarrollaremos más adelante.

\section{El triángulo de Galtung}

Johan Galtung es uno de los pensadores contemporáneos más influyentes en el tratamiento de las violencias y los conflictos. Vamos a resumir las ideas centrales de su clasificación de las violencias. La violencia, dice Galtung, es como un iceberg. Hay unos fenómenos visibles, que llamaríamos desde nuestra interpretación, manifestaciones, de modo que la parte visible es mucho más pequeña que la que no se ve. De acuerdo con esta teoría expuesta en Tras la violencia, 3R: reconstrucción, reconciliación, resolución. Afrontando los efectos visibles e invisibles de la guerra y la violencia (Galtung, 2003: 15), existen tres tipos de violencia:

\section{Figura 1. El triángulo de Galtung}

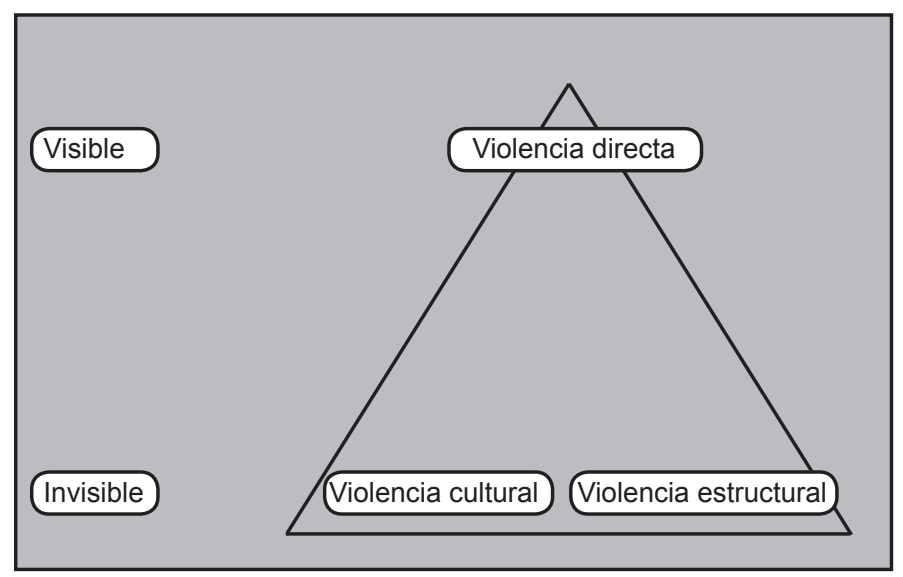

Fuente: (Galtung, 2003: 15)

1. La violencia directa, la cual es visible, se concreta con comportamientos y responde a actos de violencia.

2. La violencia estructural, (es la que está en los fundamentos del sistema), que se centra en el conjunto de estructuras que no permiten la satisfacción de las necesidades y se concreta, precisamente, en la negación de derechos y necesidades. 
3. La violencia cultural, la cual crea un marco legitimador de la violencia y se concreta en actitudes, discursos, normas, políticas.

Figura 2. El triángulo de Galtung modificado

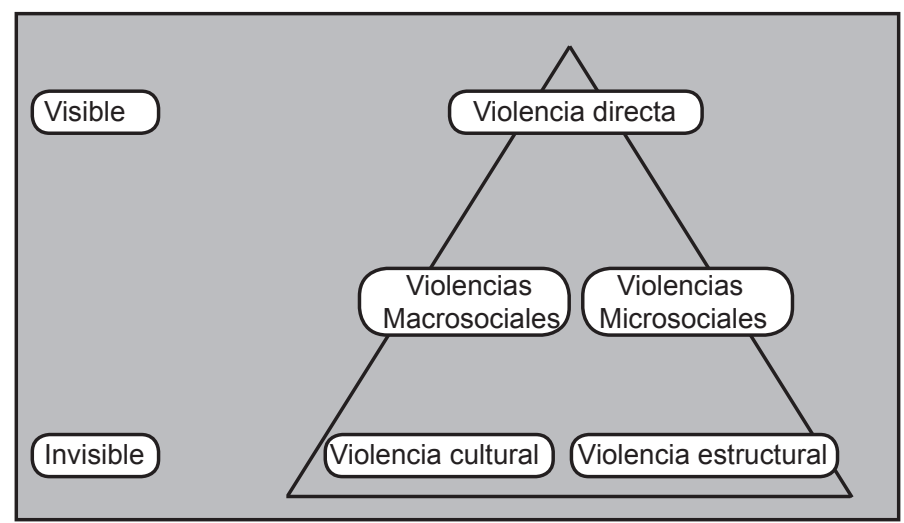

Fuente: Galtung, Modificado por Guerrero Barón, Javier.

Para Galtung, lo que vemos son las "manifestaciones" o expresiones de violencias que tienen causas y raíces profundas. La violencia directa sería un "epifenómeno" de las violencias cultural y estructural.

Para Galtung son violencias directas: Acciones agresivas o destructivas contra la naturaleza como daños contra la biodiversidad y la contaminación de espacios naturales. Acciones agresivas o destructivas contra las personas como las violaciones, los asesinatos, los robos, la violencia de género, la violencia en la familia, la violencia verbal y/o psicológica, entre otras. Las acciones agresivas o destructivas contra la colectividad como daños materiales contra edificios, infraestructuras y las guerras.

El concepto de violencia estructural se aplica cuando se producen obstáculos que sistemáticamente impiden que los miembros de una sociedad accedan a la satisfacción de las necesidades humanas básicas (supervivencia, bienestar, identidad o libertad) como resultado de los procesos de estratificación social, o de segregación permanente por razones de adscripción a un grupo social, de acceso a bienes y servicios, u otro tipo de obstáculos culturales que impiden a largo plazo que ciertos segmentos de la población tengan un desarrollo integral. Esta caracterización nos remite a conflictos entre clases sociales, contradicciones de género, etnias, nacionalidades, grupos etáreos u otros, en los que la distribución, acceso a los recursos es resuelto sistemáticamente a favor de determinados 
sectores sociales en perjuicio de los demás, debido a los mecanismos de estratificación social o privilegios establecidos y excluyentes.

La violencia estructural hace referencia especialmente al desarrollo de conflictos de intereses en el uso de los recursos materiales y sociales y permite establecer que hay situaciones de violencia directa derivada de la acción encaminada a cambiar o reforzar su posición por la vía de la fuerza o el uso de mecanismos de violencia cultural para legitimar su acción u omisión frente a situaciones de inequidad crónica, por ejemplo, el racismo, sexismo, clasismo o el colonialismo o las estigmatizaciones de diferente índole (por ejemplo es común oír decir que los pobres tienen tal condición porque quieren, usualmente por perezosos).

El concepto de Violencia Cultural fue desarrollado por el sociólogo francés Pierre Bourdieu en la década de los años 70, para describir las formas de violencia distintas a la violencia física. Aquellas manifestaciones sutiles a través de la imposición por parte de los sujetos dominantes a los sujetos dominados de sus visiones del mundo, de la asignación de roles sociales, de las categorías cognitivas y de las estructuras mentales de larga duración como lo sustenta Bourdieu en su texto "Fundamentos de una teoría de la violencia simbólica":

[...] Todo poder de violencia simbólica, o sea, todo poder que logra imponer significaciones e imponerlas como legítimas disimulando las relaciones de fuerza en que se funda su propia fuerza, añade su fuerza propia, es decir, propiamente simbólica, a esas relaciones de fuerza (Bourdieu, 2001: 15)

Es interesante además conocer la reflexión sobre el texto: "La noción de violencia simbólica en la obra de Pierre Bourdieu: una aproximación crítica" de Manuel J. Fernández aparecida en Cuadernos de trabajo social, donde se realiza un profundización del tema en análisis (Fernández, J. Manuel, 2005: 7-31).

Las violencias simbólicas son las más sutiles pues están inmersas en circunstancias que las ocultan, se interiorizan y reproducen por las costumbres sociales como se especifica en Poder, hábitus y representaciones: recorrido por el concepto de violencia simbólica en Pierre Bourdieu:

[...] Es una violencia "suave", una violencia "eufemizada", es una forma de violencia que se ejerce sobre un agente social con su complicidad, complicidad fundada en el reconocimiento-desconocimiento de las relaciones sociales externas e interiorizadas que la fundamentan. Es la manera como 
se reproducen y se refuerzan en el plano simbólico las relaciones sociales constitutivas y constituyentes de las relaciones de fuerza entre las clases (Gutiérrez, 2004: 289-300).

La violencia cultural, para Galtung, apoyándose en Bourdieu, se define como un específico conjunto de violencias simbólicas:

[...] Se expresa desde infinidad de medios (simbolismos, religión, ideología, lenguaje, arte, ciencia, leyes, medios de comunicación, educación, etc.), y cumple la función de legitimar la violencia directa y estructural, así como de inhibir o reprimir la respuesta de quienes la sufren y ofrece justificaciones para que los seres humanos, a diferencia del resto de especies, se destruyan mutuamente y sean recompensados incluso por hacerlo (Galtung, 2003: 18).

Es indudable que la caracterización introducida por Johan Galtung es un aporte a la reflexión teórica con que hemos querido contextualizar nuestra investigación. Sin embargo, aún hace falta puntualizar algunos aspectos teóricos que nos permitan comprender los objetivos propuestos para ubicar de la mejor manera la violencia escolar dentro del contexto de las culturas y realidades barriales y urbanas.

\section{Las violencias micro y macro-sociales}

Las violencias pueden agruparse en dos grandes campos de acuerdo a sus lógicas. Las violencias micro-sociales obedecen a estrategias personales y cuando más, alcanzan lógicas de pequeños grupos; usualmente son el resultado de situaciones espontáneas y no obedecen a planes o a estructuras organizadas, o semi-organizadas; es el caso de las violencias familiares o comunitarias, también conocidas como expresivas o difusas. Las otras, las violencias macrosociales, denominadas también como instrumentales u organizadas tienen que ver con estructuras complejas de la sociedad y muchas de ellas, se nutren de dinámicas de grandes estructuras, incluso de carácter global. Allí encontramos los grandes procesos económicos, políticos y sociales que nutren las violencias instrumentales y organizadas ${ }^{5}$.

5. Algunas reflexiones iniciales de este texto aparecen en Guerrero Barón y García Sánchez, (2012) 
Para el caso colombiano las organizaciones criminales, las mafias, bandas armadas y las organizaciones insurgentes o guerrilleras y contrainsurgentes del paramilitarismo (muchas de ellas variedades de organizaciones criminales que por las características del conflicto han convergido en la lucha antiguerrillera), que alimentan el conflicto armado.

Podríamos entonces establecer dos grandes polos en un continuum que nos ayude a comprender la dinámica y naturaleza de las relaciones violentas al interior de la sociedad: en un extremo tendríamos las violencias individuales, por motivaciones puramente espontáneas sin ningún tipo de plan preconcebido, y en el otro extremo tendríamos las violencias altamente organizadas, planificadas e instrumentadas para determinados fines, por ejemplo las organizaciones del crimen transnacional con sus aparatos de justicia privada, sus redes sicariales, sus mecanismos de toma de decisiones, o las organizaciones constituidas para ejercer violencias permanentes con determinados fines políticos, destrucción del Estado o derrocamiento de un gobierno; pero de este tipo de violencias organizadas no se pueden descartar los Estados, entre cuyas funciones está el ejercicio de la violencia y la justicia así, dentro del contexto jurídico y político la denominemos violencia legítima. Muchos de estos organismos estatales han ejercido y ejercen violencias sistemáticas e incluso el terrorismo de Estado, contra su población y contra otros pueblos o se han convertido en organizaciones al servicio de intereses de una minoría e incluso de clanes o núcleos familiares. Entre los dos polos existen muchas modalidades intermedias de acuerdo a las condiciones sociales de cada contexto.

Aceptando esta tipología podríamos aportar una revisión de las tres categorías propuestas por la OMS. Si sociológicamente atendemos a las lógicas propias de cada una de estas modalidades, veríamos que la violencia denominada como auto infligida e Interpersonal, cabría dentro de lo que en nuestra propia clasificación llamaríamos violencias microsociales y en la categoría de violencia colectiva las que dicha clasificación denomina como subcategorías social, política y económica. Como se ve esta también es incompleta.

Hay lógicas culturales que son macro. Por ejemplo las violencias de tipo étnico o religioso, y muchas de las violencias simbólicas merecerían subcategorías. Cada vez se hace más necesario el reconocimiento de condiciones estructurales que generan violencia para diferenciarlas de situaciones coyunturales y la negación permanente de derechos de primera, segunda y tercera generación. Creemos que es necesaria una reflexión teórica al respecto y que estas precisiones son más adecuadas de acuerdo a las necesidades de esta investigación. 
A menudo, las causas de la violencia directa están relacionadas con situaciones de violencia estructural y/o justificadas por la violencia cultural, en el sentido señalado por Bourdieu: muchas situaciones son consecuencia de un abuso de poder que recae sobre un grupo oprimido, o de una situación de injusticia social (de un reparto de recursos insuficiente, de una gran desigualdad en la renta de las personas, dificultad de acceso a los servicios sociales y a la red sanitaria), situaciones que reciben el espaldarazo de discursos que justifican estas violencias.

\section{Figura 3. Campos de violencia}

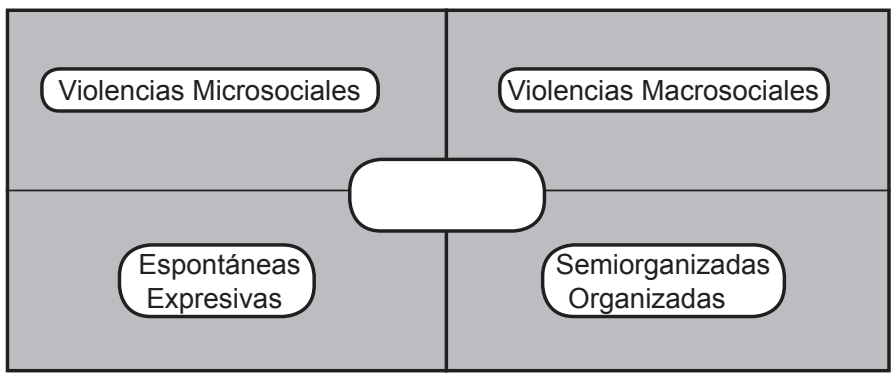

Fuente: Construcción a partir de fuentes revisadas en el marco del proyecto "Violencia escolar en Bogotá: una mirada desde los maestros, las familias y los jóvenes".

Tenemos que ver estas tipologías como lo que este tipo de construcción imaginaria significa. Simplemente nos ayudan a mirar la realidad. Por ahora lo que queremos resaltar es la gran diferencia en sus lógicas y su naturaleza.

\section{Figura 4. Diferencia entre violencias micro y macro-social}

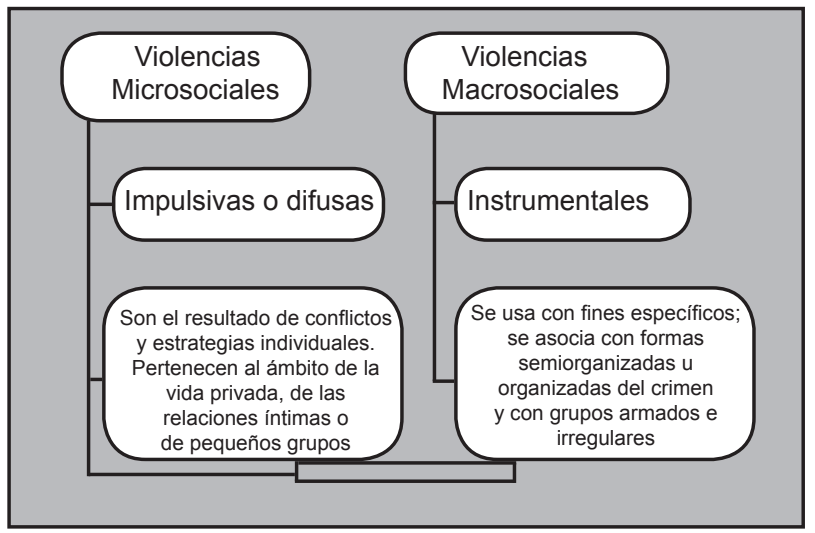

Fuente: Construcción a partir de fuentes revisadas en el marco del proyecto "Violencia escolar en Bogotá: una mirada desde los maestros, las familias y los jóvenes". 
Muchas relaciones y acciones violentas pueden tener de una y de otra. Hay diferentes situaciones que se repiten en la vida cotidiana y van creando situaciones de convivencia y tolerancia con la violencia que la "naturalizan" y la banalizan.

Sin embargo, los dos grandes campos de las violencias, micro y macro, no están asépticamente separados pues se pueden establecer todo tipo de hibridaciones. Las conexiones entre unas y otras son el fundamento de fenómenos de expansión de las violencias en algunas sociedades del mundo, especialmente en ambientes urbanos en sociedades en situación de conflicto o post-conflicto en donde se producen grandes desórdenes sociales con altas dosis de violencias.

Los casos más notorios recientemente fueron las situaciones del post-conflicto de las guerras centroamericanas, especialmente de Guatemala, Nicaragua y Salvador con el surgimiento de las llamadas "maras" o pandillas predominantemente juveniles que aumentaron extraordinariamente su tamaño, convirtiéndose en un fenómeno internacional y cuyas acciones han afectado incluso a ciudades estadounidenses.

Casos de expansión de las violencias donde son notorias las articulaciones entre las violencias micro y macro fue la Colombia de los años ochenta y noventa, las situaciones extremas en las favelas de Río de Janeiro dominadas por las pandillas o la actual situación del norte de México con la expansión del narcotráfico y las acciones criminales de los carteles. Aunque ninguna sociedad está exenta de vivir situaciones similares.

Para nuestro medio quizás el más relevante y notorio internacionalmente, en términos generales, fue el mencionado caso de la ciudad de Medellín en los años ochenta y noventa del siglo pasado, cuando a la organización de milicias urbanas por parte de las organizaciones guerrilleras que fueron abandonadas por estas a lo que sobrevino la cooptación de estas organizaciones, sumado a la de muchas pandillas y grupos juveniles barriales por parte de las organizaciones del narcotráfico, generando un auge del sicariato y la emergencia de grupos autónomos de jóvenes que de la pandilla barrial hicieron rápido tránsito a bandas al servicio de los carteles, llegando a situaciones críticas que pusieron en riesgo a toda la sociedad colombiana con sus acciones sicariales, extorsivas y, en general, criminales que desbordaron a las instituciones. En esas circunstancias las violencias intrafamiliares se exacerbaron y se entremezclaron con otras expresiones violentas, tales como las riñas con saldos fatales, los atracos callejeros, las amenazas, cobros de "vacunas", secuestros, asaltos bancarios, entre otras 
modalidades delincuenciales. A finales de los años ochenta los carteles u organizaciones del narcotráfico, además de desatar su guerra contra la sociedad, con carros-bomba, magnicidios contra jueces, políticos, secuestros, en una guerra contra la extradición de los capos, además de enfrentamientos entre los carteles de Cali y Medellín, guerra contra la policía asesinando cerca de 200 agentes y oficiales, comandantes, gobernador de Antioquia, entre otros; el clima delincuencial permitió el aumento de otros delitos como robo de automóviles, asaltos a mano armada. La inseguridad generalizada daba la sensación de caos e impunidad. Los grandes crímenes como los magnicidios contra personalidades de gran prestigio y figuración, hacían ver que cualquiera podía ser el próximo, además de crear la sensación de que los demás delitos de los ciudadanos corrientes no eran graves, creando un ambiente de tolerancia con el delito.

Entre tanto los delitos correspondientes a riñas, violencia intrafamiliar, escolar, es decir, las violencias micro también aumentaron significativamente. En situaciones de exacerbación de las violencias la percepción es que todas están interconectadas, como en efecto, los dos campos se retroalimentan. Pero no obedecen a las mismas causas. Siempre, aún en estas circunstancias dramáticas, habrá la posibilidad de distinguirlas, separarlas analíticamente y darles tratamientos distintos desde políticas públicas diferenciadas.

Es necesario reconocer que la situación en las ciudades grandes se hace cada vez más compleja y borrosa la frontera entre las violencias macro y micro-sociales. En el caso de Bogotá, la correlación entre uno y otro indicador, por localidades, es del $94 \%$. Las localidades en donde se presenta una alta incidencia de homicidios instrumentales son precisamente aquellas donde se registra un mayor número de casos impulsivos, especialmente muertes por riña, según información publicada en Violencia homicida y estructuras criminales en Bogotá (Llorente, 2000: 14). En otras palabras las diferentes formas de violencia cada vez más se conectan y se retroalimentan. Sobrarían ejemplos. Pero para nuestros análisis debemos comprender y tener claro que son fenómenos de naturaleza distinta que requieren acciones también distintas.

\section{Las violencias juveniles:}

\section{un puente entre las violencias micro y macro-sociales}

En la coyuntura actual de la sociedad mundial y colombiana son cada vez más frecuentes y notorias las violencias en las que participan los jóvenes en diversos escenarios y situaciones. Aunque hay que advertir que existen estereotipos 
prejuiciados que quieren presentar como violentos o delincuenciales los grupos juveniles de toda índole. Hecha esta salvedad, es innegable que a nivel global se está dando el fenómeno del involucramiento cada vez mayor de sectores de la población joven en situaciones violentas o en circunstancias de violencia permanente o semipermanente que la hacen proclive a situaciones altamente vulnerables dada, la permanente instrumentación para la participación en ambientes delincuenciales de variada naturaleza. Una hipótesis ronda este trabajo: la conexión más eficiente en la sociedad contemporánea entre las violencias macro y micro son las multivariadas expresiones de violencia juvenil, dada por sus estructuras móviles y semiorganizadas que fácilmente derivan en situaciones permanentes o esporádicas de delincuencia que las hace proclives a verse involucradas en circunstancias violentas. Lo que a su vez las coloca en la riesgosa frontera de las violencias organizadas.

Figura 5. Violencias juveniles: puente entre los campos de las violencias

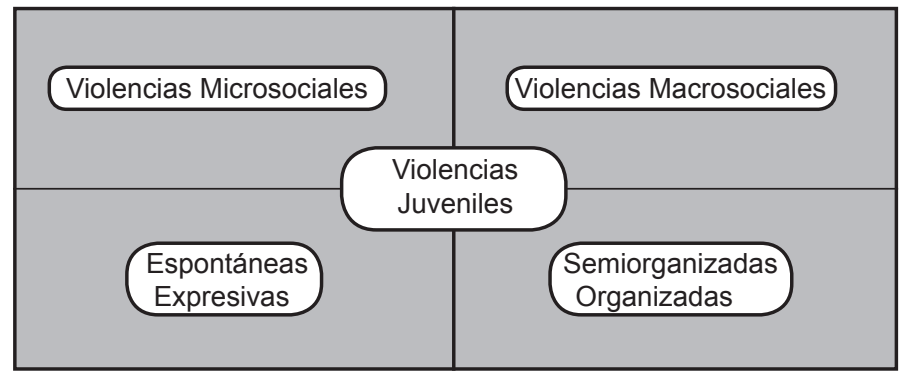

Fuente. Construcción a partir de fuentes revisadas en el marco del proyecto "Violencia escolar en Bogotá: una mirada desde los maestros, las familias y los jóvenes".

\section{El debilitamiento del concepto de autoridad ${ }^{6}$}

La crisis de las sociedades globales de comienzos del siglo XXI está marcada por signos mundiales que afectan transversalmente la cultura moderna contemporánea que algunos Ilaman posmoderna. El derrumbe acelerado de las estructuras patriarcales ha cuestionado desde sus raíces la noción misma de autoridad ligada culturalmente a las imágenes masculinas, especialmente de la figura del padre, que transita hacia la autoridad compartida por parte de la familia y con

6. Ver in extenso este planteamiento en: García-Sánchez, B. Y. \& Guerrero-Barón, J. (2011). Nuevas concepciones de autoridad y cambios en las relaciones de violencia en la familia y la escuela. Magis, Revista Internacional de Investigación en Educación, 4 (8) Edición especial La violencia en las escuelas, 297-318. 
gran presencia femenina, que en derecho se denomina "autoridad parental" y aún este tipo de autoridad erosionada o reemplazada por la noción más que de autoridad, de responsabilidad parental. Las viejas nociones han sido desplazadas por la emergencia de nuevos derechos de las mujeres, los niños y las niñas, los adolescentes y los jóvenes, como se refleja en el Código de Infancia y Adolescencia que rige en el país.

La escuela, depositaria de un poder similar al de los padres, poder derivado a su vez de la delegación del poder estatal y patriarcal, también ha visto deteriorados sus viejos poderes omnímodos. Asociados a estos fenómenos también vivimos la crisis del monopolio de los poderes del Estado Nacional, que se auto designó depositario y árbitro de todas las violencias por parte de los ciudadanos. Modelo que indudablemente ha perdido funcionalidad y, sobre todo, credibilidad por parte de nociones jurídicas garantistas, nuevos sujetos de derecho y nuevos fundamentos y generaciones de derechos y obligaciones a la luz de interpretaciones de la ley.

\section{La autonomización de las mujeres y los jóvenes}

Durante la segunda guerra mundial y en las décadas y en los años inmediatamente posteriores se produjo un fenómeno sin precedentes en la historia de occidente: la vinculación de las mujeres a la economía industrial primero de la guerra y posteriormente de la reconstrucción. Mientras los hombres iban a la guerra, las mujeres masivamente salieron a trabajar en la revolución del aluminio, produciendo millares de aviones, barcos, "jeeps", camiones. Los oficios administrativos y contables fueron inmediatamente "capturados" por mujeres y muchas plazas de oficios reservados para el "sexo fuerte" fueron paulatinamente asignados a ellas que mostraron ventajas significativas para los empleadores, rompiendo mitos sobre el "sexo débil". Estas circunstancias hicieron que la mujer saliera del ámbito doméstico. Por diferentes razones en Europa la reconstrucción la hicieron millones de viudas sobrevivientes, porque millones de hombres murieron o desaparecieron, asumiendo ellas de manera notoriamente eficiente el control de sus vidas y sus sociedades. En uno y otro lado del Atlántico, con diferentes características, hubo un hecho notorio en el que viudas y separadas tuvieron que reconstruir el mundo norteamericano y europeo, por cuantos muchos de sus maridos murieron o no regresaron.

Simultáneamente, la euforia económica de la posguerra que redistribuyó los mercados indujo a una acelerada modernización que puso en auge la tercera 
revolución industrial, lo que aumentó la movilidad de la población trabajadora y estudiantil en otras partes del planeta. La primera generación de hijos que se socializó en la complejidad de relaciones de las nuevas formas familiares, educados ya no por las madres domésticas sino por educadores profesionales, maestros y cuidadores desde edades muy tempranas, produjeron la primera revolución de los jóvenes que irrumpió con fuerza en los años sesenta y setenta del siglo XX, primero en la música y danza propia, luego en revueltas políticas y sociales autónomas como mayo de 1968 en París, la primavera de Praga y Tlatelolco en México en el mismo año. Simultáneamente se expandía por el mundo el movimiento hippie con sus antivalores contra el "establecimiento" y contra la guerra de Vietnam que con mayor o menor radicalidad se reflejó en las contraculturas juveniles latinoamericanas.

Posteriormente a esta primera revolución, otros jóvenes de las generaciones de entonces participaron activamente en las revoluciones del 1989 en Europa central y oriental conocida como "el otoño de las naciones" que comenzó en Polonia, Alemania oriental y se expandió a Checoslovaquia, Bulgaria, y Hungría. Revoluciones pacíficas, con excepción de Rumania, que llevaron al derrumbe de la Unión Soviética en 1991 y que dieron rienda suelta a un "big bang" de cambios culturales encadenados de la llamada "condición posmoderna" donde lo único cierto es el principio de incertidumbre y "todo lo sólido se desvanece en el aire".

A partir de la segunda década de los noventa estamos viviendo de manera acelerada la "revolución digital" — cognitiva y emocional— que además está inmersa en la más avanzada revolución tecnológica jamás vista.

Cada generación aprendió de la anterior la radicalidad y profundidad de sus símbolos y desde entonces, juventud es rebeldía, pero sobre todo es autonomía y apropiación de sí mismos, del cuerpo y del espacio.

Esta autonomización de los jóvenes trae una novedad en los albores del siglo $X X I$, es que si bien las anteriores revoluciones juveniles fueron predominantemente de jóvenes universitarios, los movimientos actuales tienen sus dinámicas en la secundaria y cada vez involucra grupos etáreos más tempranos.

En este panorama, los grupos naturales de jóvenes y adolescentes, sus estructuras de pares, comúnmente conocidas en nuestro medio como "culturas" juveniles, "tribus urbanas", y en colombiano, "parches" o pandillas, se convierten en expresiones primero incomprendidas y desconocidas para padres, madres y maestros. Con sus pintas, sus tatuajes, sus piercing, sus músicas y sus grafitis, 
que además son reprimidas y ocultadas bajo los códigos y manuales de convivencia escolar y con la dictadura de los "uniformes", con la característica de que sus identidades son tan fuertes que en momentos y circunstancias parecen sobrepasar u opacar los vínculos primordiales de la familia y la escuela. Entre más los reprimen y desconocen se abren las puertas de la rebeldía y la cultura de la desobediencia, aprendida de las generaciones antecesoras. Estos son los síntomas fundamentales del malestar de la cultura latinoamericana que se manifiesta en el malestar de la escuela, de la familia y del Estado-nación.

\section{Inserción juvenil en el mundo de la incertidumbre}

Cada vez son más notorias las reacciones colectivas de los jóvenes a nivel mundial, no solamente en las culturas occidentales sino en sociedades altamente autoritarias. En los momento de la escritura de este texto, primer semestre de 2011, se presentaban revueltas, revoluciones y protestas de movimientos juveniles de variada naturaleza e intensidad en diversas partes del mundo: el movimiento de los "indignados" en Europa; Variedad de revueltas la juventud árabe desde 20102011 en un movimiento denominado por la prensa como "la Primavera árabe" de gran similitud: Rebelión e intervención militar internacional en Libia y Protestas en Siria y Yemen, Revolución egipcia con derrocamiento del gobernante, Revueltas en Jordania, Rebelión en Libia, con intervención militar de la OTAN y la Unión Europea, protestas en Argelia, Yemen, Yibuti, Omán, Siria, Bahréin, Marruecos, Sahara Occidental, y en el mundo islámico se han dado protestas en Irán, además de protestas sofocadas en China. Por el lado de occidente, en España se han presentado grandes movilizaciones predominantemente juveniles con los movimientos de "Indignados", "15-M" y "Democracia Real YA", además de revueltas estudiantiles generalizadas en Chile y Colombia. En Estados Unidos importantes movilizaciones han sido contra el capital financiero especialmente el movimiento de "Ocupa Wall Street"7. El movimiento en septiembre de 2011 en el distrito financiero de Nueva York para clamar contra la crisis económica y los abusos del sector bancario y buscar que "se escuche la voz del $99 \%$ del país y no la del $1 \%$ que sigue enriqueciéndose", según su página web.

7. La Cadena CNN tituló: "Protesta en Wall Street, espejo mundial. Tras el levantamiento en Oriente Medio, el movimiento en NY refleja el descontento ante las elites; la sensación es que los jóvenes y la clase media están pagando muy alto malos manejos económicos". Publicado: Martes, 11 de octubre de 2011 a las 13:27. http://www.cnnexpansion.com/economia/2011/10/11/protesta-enwall-street-espejo-mundial. Visitado: 27-02.2012.

8. Ver versión de Univisión: http: //univisionnuevayork.univision.com/noticias/local/article /2011-1002/se-extienden-las-protestas-contra-wall-street. Visitado: 27-02.2012. 
En resumen, la creciente pérdida del control del mundo de los jóvenes por parte del mundo de los adultos ha sido producto de las revoluciones culturales más importantes del siglo XX. La revolución de las mujeres, cuya consecuencia ha sido la revolución de los jóvenes, donde unas y otros se autonomizaron de las amarras que los contenían en la vieja sociedad patriarcal es uno de los fenómenos sociales fundamentales del milenio que terminó y del que comienza.

En este panorama, los grupos naturales de jóvenes, sus estructuras de pares, comúnmente conocidas en nuestro medio como "culturas" juveniles, "tribus urbanas", parches o pandillas, se han convertido en estructuras que denominaremos provisionalmente "semiorganizadas" o "blandas", que fácilmente se mueven en la frontera de la legalidad o se pueden transformar en organizaciones en "conflicto con la ley" lo que las hace fácilmente instrumentables por organizaciones "para el crimen" o por estructuras "duras" y permanente del crimen organizado. (Pero advertimos que ese es un riesgo no un destino trazado inmodificablemente).

$Y$ no es un destino pero si es una posibilidad por las condiciones sociales del contexto general en que se desenvuelven esos jóvenes. Hay muchas fuerzas y circunstancias que los empujan hacia allá. La primera de ellas es la incomprensión y la intolerancia intergeneracional.

Los jóvenes sienten que no tienen espacios en la vieja sociedad, así lo expresan tanto estudios de opinión como sus permanentes manifestaciones de rebeldía que son ignoradas por "mundo de lo establecido", o "establecimiento" o "mundo de los adultos" o los "viejos" como ellos mismos denominan a las generaciones mayores.

En los países desarrollados se nota de manera imperiosa esa situación: el desempleo juvenil se ha disparado y los contratos chatarra agobian a la mayoría de trabajadores jóvenes o no. En América Latina no hay esa rebeldía organizada contra el desempleo juvenil porque nunca ha existido la tradición de dar empleo a los jóvenes. Si pueden estudiar dentro de las bajas tasas de cobertura de muchos de nuestros países, bien, si no quedan a la deriva en un mundo donde se insertarán de cualquier manera. Si no, quedarán sin rumbo en la barriada o con inserción precaria en el mercado laboral secundario: en el de lo que nadie quiere hacer, en lo que se hace por cortas temporadas, "en lo que resulte" o en la "micro empresa" que él pueda inventar, en su único mundo posible: el de la incertidumbre y el rebusque. 


\section{La nueva miseria urbana}

A este conjunto de fenómenos se le suma el deterioro creciente de la ciudad latinoamericana y mundial. Numerosos analistas sociales llaman la atención sobre el fenómeno. Títulos de Loïc Wacquant como Parias urbanos, marginalidad en la ciudad a comienzos del milenio (2001), Los condenados de la ciudad: guetos, periferias y Estado (2007), y de Mike Davis como Planeta de ciudades miseria (2008), plasman un cuadro dramático que ya había sido dibujado por Bourdieu, Castells y otros sociólogos y antropólogos que anticipaban un cuadro surrealistamente apocalíptico. Muchos de estos trabajos, a su manera realizan una etnografía de la miseria y la opulencia como dos caras de la misma moneda del capitalismo posmoderno.

Ninguna región y casi ningún país del centro o de la periferia puede decir que está blindado contra estos fenómenos de las brechas socioeconómicos, de las culturas de la exclusión que genera la pobreza e incluso de guetos de miseria.

Las noticias hablan, por ejemplo, del aumento de los sin-techo y los sin hogar en los Estados Unidos. Cada vez es más frecuentes noticias de este tipo que anuncian la miseria en Washington o New York o en cualquier ciudad grande o pequeña, fenómeno que quedó al desnudo ante los ojos del mundo en 2005 la miseria del sur de la gran nación norteamericana. Pero hoy no hay una de esas catástrofes por causas naturales que suelen encubrir las grandes desigualdades y que se ensañan, por norma, con la población más vulnerable. Hoy está al desnudo una catástrofe social:

[...] La BBC visitó en los EE.UU., algunos campamentos de los sin-techo, cada vez más numerosos, desde que explotó la crisis del 2008. Los datos oficiales señalan que cerca de 47 millones de norteamericanos viven por debajo de la línea de pobreza y esta cifra sigue aumentando.

Actualmente, hay 13 millones de desocupados, 3 millones más que los que había cuando Barack Obama asumió la presidencia en el 2008. Algunas estimaciones calculan que cerca de 5.000 personas se han visto obligadas a vivir en carpas en campamentos de los sin-techo, esparcidos en 55 ciudades estadounidenses. El más grande es el Pinella Hope, en la Florida, en la zona más conocida como sede de Disney World.

Una organización católica ofrece algunos servicios a sus habitantes, tales como máquinas lavarropas, computadoras, teléfonos, etc. Muchos campamentos se 
organizan y mantienen reuniones para distribuirse las tareas comunitarias. Para algunos, con pocas perspectivas de encontrar trabajo, las carpas son viviendas semipermanentes ${ }^{9}$.

Pero el problema no es solo en los países desarrollados: en los no desarrollados es obviamente peor; el problema es mundial:

[...] Las víctimas de la catástrofe que ha producido el capitalismo tardío están servidas. Como ha advertido Jan Breman en The labouring poor: Patterns of exploitation, subordination, and exclusión, refiriéndose a India, "se ha llegado a un punto de no retorno, donde un ejército de reserva, que está esperando su incorporación al proceso productivo, se ve estigmatizado como excedente permanente de población, considerado un peso excesivo que ni la sociedad ni la economía pueden asumir, ni ahora ni en el futuro. Esta evolución es en mi opinión la verdadera crisis del capitalismo mundial" (Breman, 2003: 13).

[...] Simultáneamente, como reconocía gravemente la CIA en 2002, "a finales de la década de 1990 hay un sorprendente millardo de trabajadores, la mayor parte en el hemisferio sur, que representan a un tercio de la fuerza de trabajo mundial y que están subempleados o carecen por completo de empleo"10.

Aparte de las recetas de De Soto ${ }^{11}$ sobre informalidad y flexibilidad, no hay ningún plan oficial que pretenda incorporar a esta enorme excedencia de trabajo a la corriente principal de la economía mundial como lo sostiene Mike Davis en Planeta de ciudades miseria (Davis, 2008: 223).

El diagnóstico es repetitivo: la nueva miseria urbana, un fenómeno surgido a caballo de la incesante polarización económica desatada al interior de las ciudades. Desarrollado durante las últimas décadas del siglo $\mathrm{XX}$, este proceso dio origen a un paisaje urbano en el que conviven, separadas a veces por pocos metros, la mayor de las opulencias burguesas junto a la miseria más estremecedora como analiza Enrique Mozzo en: Capitalismo hoy - La nueva marginalidad, acerca del

9. Sobre el tema es oportuno leer el Periódico Virtual Guajirita Soy. Aumentan los sin techo en Estados Unidos. Recuperado el 27 de 02 de 2012 de http://guajiritasoy.blogspot.com/2012/02/ aumentan-los-sin-techo-en-estados.html.

10. US. Government. (2002). Central Intelligence Agency, The World Factbook, Washington DC, p. 80.

11. El autor se refiere al economista peruano Hernando de Soto, autor de El otro sendero y El misterio del capital, un elogio de la informalidad y la pobreza como punto de partida para un modelo de desarrollo alternativo. 
libro Parias Urbanos. Marginalidad en la ciudad a comienzos del milenio, de Loic Wacquant.

Esto ha dado lugar a lo que Manuel Castells, ha denominado "ciudades duales", donde coexisten zonas de "riqueza impúdica" que lindan con extensas zonas de miseria, en donde los jóvenes llevan la peor parte de las formas del capitalismo posmoderno: acceso restringido a la educación de calidad, especialmente a la formación superior, ausencia de vínculo con la economía formal, precarización del contrato laboral, inestabilidad, ausencia de seguridad social, deterioro creciente de los salarios, es decir, el peor mundo posible, el mundo de la desesperanza, que la sociedad tiene que pagar en términos de inseguridad, banalización de la violencia, criminalización de la barriada.

Esta realidad se puede resumir en lo que Pierre Bourdieu denominó como la "ley de la conservación de la violencia":

[...] No se puede jugar con la ley de la conservación de la violencia: toda la violencia se paga $y$, por ejemplo, la violencia estructural ejercida por los mercados financieros, en las formas de despidos, pérdida de seguridad, etcétera, es equiparada, más tarde o más temprano, en forma de suicidios, crimen y delincuencia, adicción a las drogas, alcoholismo, un sinnúmero de pequeños y grandes actos de violencia cotidiana. (Mozzo, 2001)

Este campo de problemas será objeto de reflexión en el capítulo propio, más adelante.

\section{Juventud, violencia, modernidad y sociedad civil}

Las frecuentes situaciones de exacerbación violenta que vive la sociedad del siglo XXI obligan necesariamente a mirar el papel de la violencia en la sociedad posmoderna. La modernidad "teóricamente" había construido una renuncia a la violencia por parte de los ciudadanos, era el Estado el único que tenía capacidad de ejercerla legítimamente. Este ideal fracasó ante el hecho de que los excesos de los Estados, incluso de los que se proclamaron defensores universales de la democracia han incurrido en actos de violencias ilegítimas ${ }^{12}$. Estos hechos ha-

12. El hecho de que algunos estados en el siglo $X X$ incurrieron en los más graves hechos de violencia de la historia de la humanidad, como el holocausto nazi, o hechos como los excesos del Estado soviético de la era estaliniana, a nombre del socialismo, para solamente poner algunos ejemplos, entre los más recurridos, para no hablar de hechos no suficientemente analizados como los bombardeos a Hiroshima y Nagazaki, como casos de extrema violencia humana, amparados en los fines y los medios de la más cruel y abierta de todas la violencias: la guerra total, nos haría pensar o que la modernidad fracasó en sus ideales o que estas fueron siempre palabras vacías. 
cen que la reflexión sobre la violencia implique una reflexión ética no solamente desde el Estado, sino desde la sociedad civil.

Pero ¿qué es la sociedad civil y cual su papel frente a la violencia? La creación de esos "Estados modernos" llevó a pensar que sociedad civil es todo aquello que no es el Estado, el mundo de los ciudadanos, y ese mundo afuera era el mundo de la violencia. El mundo de todos contra todos que debía ser arbitrado.

Las más importantes reflexiones sobre la violencia se hacen desde la función del Estado.

Sin embargo teniendo en cuenta que las violencias sociales que nos ocupan en este trabajo son violencias "civiles" que ni siquiera son manifestaciones entre ciudadanos formados sino entre niños y jóvenes, las más de las veces, además de la queja permanente del mal funcionamiento del Estado, es poco lo que se puede avanzar.

Las violencias de los jóvenes, de los escolares, de los barrios, se convierten en pretexto para la añoranza de un Estado autoritario y policial que imponga orden, que ayude a los padres a que sus hijos "obedezcan". Un Estado que intervenga a toda hora e imponga el orden que los ciudadanos somos incapaces de afrontar.

Podemos ilustrar este dilema de la sociedad civil y el Estado: Los padres le reclaman al maestro que la escuela no educa bien a los jóvenes, los maestros reclaman a los padres que no imponen su autoridad y que los jóvenes no les obedecen y unos y otros apelan a las comisarías de familia y al ICBF para resolver los problemas, es decir: dejan en manos del Estado la solución. Y esta es una instancia incierta. Unos y otros y las burocracias apelan a medidas como el copamiento policial de la escuelas, la prohibición de las drogas, la prohibición del alcohol y hasta los "toques de queda" juveniles. Y muchos padres y madres, que una vez fueron jóvenes, se alegran con este tipo de medidas.

Vivimos la era de la incivilidad. ¿Pero qué es la civilidad?

[...] La civilidad era el fantasma que atemorizaba a la sociedad civil. A este respecto, la civilización se entendía como un proyecto para solucionar el eterno problema que plantea descargar, reducir o sublimar la violencia; la incivilidad era el eterno enemigo de la sociedad civil. Así pues, la palabra "civilización" denota un proceso histórico en marcha, en el que el civismo, terminó estático, era tanto la meta como el resultado de la transformación de la conducta incivil" (Keane, 2000: 26). 
Pero la civilidad es un proceso histórico. Lo que hoy consideramos aceptable en los comportamientos "ciudadanos" fue producto de un largo proceso histórico, para lo cual es imprescindible hacer referencia al principal texto de Norbert Elias: El proceso de la civilización: Investigaciones sociogenéticas y psicogenéticas.

[...] Elías sostiene que la conducta y los sentimientos sociales experimentaron un cambio drástico a partir del siglo XVI, especialmente en los círculos corteses de la clase alta. Los códigos de conducta se hicieron más estrictos, más diferenciados y universales, pero también más suaves y atemperados, evitando al mismo tiempo los excesos propios del egoísmo y del servilismo. Se reprimió el comportamiento espontáneo, y los hombres que antes comían de la misma fuente, bebían del mismo vaso o reñían en público quedaron separados por un muro hecho de contención y vergüenza hacia las funciones corporales ajenas; se restringieron los impulsos físicos (defecar, orinar y ventosear) mediante prohibiciones interiorizadas y sometidas a nuevas normas de "intimidad"; la mojigatería invadió las ceremonias nupciales, la prostitución y los comentarios a propósito del sexo; el lenguaje se hizo más delicado, e incluso la muerte se convirtió en un asunto embarazoso para los vivos. La expresión de los placeres violentos, ya fuera mutilar a un enemigo en la guerra o quemar un gato vivo (una ceremonia anual en París) comenzó a considerarse brutal y repulsiva. Elías demuestra que esta transformación se halla íntimamente relacionada con la formación del Estado, en particular con la sujeción de la clase de los guerreros a un control más estricto, y con la conversión de los nobles en cortesanos" (Keane, 2000: 29-30).

No en vano, civilidad, cortesía, ciudadanía, son conceptos profundamente interrelacionados. El centro del proceso civilizatorio desde esta perspectiva tiene que ver ineludiblemente con la hegemonización de una fuerza superior a los individuos cualquiera fuera su condición y su riqueza: El Estado.

[...] El Estado moderno funciona como un instrumento de dominación, haciendo de la fuerza armada su centro, y ello es así porque su historia comenzó desarmando a los señores feudales, a las milicias comunales, a los mercenarios, a los piratas y a los duelistas de la aristocracia. Por tanto, los efectos que produce un Estado moderno pueden ser mucho más terribles que los que se derivaban de los sistemas políticos anteriores. Su monopolio del empleo de la fuerza, como subrayó Hobbes, coloca a sus súbditos bajo la permanente amenaza de la violencia". (33)

El centro de todo este proceso de varios siglos de historia humana no es otro que "La pacificación de la vida cotidiana". Pero, ¿qué hacer cuando los Estados pierden su legitimidad o su efectividad en el control de las fuerzas violentas, 
Ilámese, pandillas, bandas, criminalidad organizada, estructuras mafiosas, empresas ilegales, el proceso que nos transforma "en seres indefensos, en juguetes de unos gestores de la coerción probablemente siniestros?" (38)

El problema es cuando, como sucede actualmente en muchas sociedades del mundo, en medio del desorden social de la destrucción de la civilización industrial en mayor o menor medida en las ciudades del mundo, debido a las condiciones concretas que ya hemos enunciado, cuando del seno de la sociedad civil emergen fenómenos violentos que no tienen control o su control se sale coyunturalmente de las manos del Estado y la sociedad.

El caso colombiano es más crítico y no es el único, porque el Estado mismo ha sido permeado por organizaciones ilegales y muchos de sus organismos pueden no obedecer a lógicas públicas y el monopolio de la violencia. La metáfora que plantea Keane:

[...] La concentración de los instrumentos físicos de la violencia, normalmente controlados y gestionados por un gobierno y empleados por sus órganos ejecutivos, es decir el ejército y la policía, es, como la mayoría de las invenciones humanas, profundamente ambigua. Según Elías, la invención de un Estado que monopoliza la fuerza física no es un hecho menos ambiguo que la domesticación del fuego, que si bien representó un progreso en la preparación de los alimentos también dio a los bárbaros la posibilidad de incendiar las chozas y las casas. (32)

El sentido del planteamiento de Keane y Elías tiene mucho sentido. Hemos concentrado toda la confianza como ciudadanos en el Estado pero nadie nos puede garantizar que ese uso de la violencia no se devuelva contra el ciudadano y nos transformemos "en seres indefensos, en juguetes de unos siniestros gestores de la coerción".

Y no es simplemente en el plano del uso de la violencia en contra del ciudadano que es tan frecuente y evidente. (En Colombia cerca de 2.000 jóvenes y al parecer son muchos más, fueron reclutados y asesinados fuera de combate por el ejército que estaba para defenderlos y en Barcelona cientos de heridos en la Plaza de Cataluña, en los campamentos del 15-M porque había que despejar la ciudad para un partido internacional de futbol). Es también en el plano económico. Ningún joven, a no ser que haya vivido épocas "más normales" del Estado de Bienestar, puede creer que el Estado es su protector. Ellos han vivido épocas más cercanas en las que medidas protectoras del capital financiero le han qui- 
tado las viviendas a las familias, que no pueden pagar porque no hay empleos dignos, en las burbujas inmobiliarias que los financistas mismos han creado para su lucro megamillonario, descalabro que luego es subsidiado con fondos públicos, lo mismo en Estados Unidos que en la crisis inmobiliaria colombiana del año 1998, donde 800.000 familias perdieron su casa y ningún banco se quebró. ¿Cómo convencer a un joven de hoy, desempleado, sin futuro, de que el Estado es su protector y el protector de su nación o de su familia?

Estos planteamientos simplemente quieren colocar en el centro la profunda crisis de la modernidad, desde sus fundamentos mismos: Su percepción es que ni el Estado es el depositario de la violencia legítima, ni es tampoco el depositario del bien común.

Pero eso es respecto a las generalidades de la relación moderna ciudadanoEstado, con sus espejismos de la ilusión democrática. Ahora acerquemos el lente. Este trabajo de investigación al que refieren estos textos ha tratado de mirar empíricamente qué está pasando en el tejido mismo de la sociedad moderna que falla desde sus mismos cimientos. La violencia escolar y sus manifestaciones barriales son expresión de fallas telúricas de la estructuración de esa sociedad civil, cuya principal manifestación de incivilidad es la violencia. Y máxime en sus formas más cercanas y emotivas: la familia, la escuela y el vecindario.

¿Puede realmente el Estado garantizar convivencia en los pequeños resquicios de las relaciones micro-sociales? ¿Está en capacidad el Estado de impedir el bullying en las aulas? ¿O el maltrato en el seno de las familias? ¿O en los callejones de los barrios? ¿Pretende el Estado, como antes lo hicieron las Iglesias, legislar sobre los sentimientos y afectos de las personas? Por lo menos mientras se reconstruye la idea del Estado posmoderno la garantía de no-violencia debe ser construcción desde los sujetos, auto-regulación de la sociedad civil, construcción de comunidad solidaria en esos pequeños espacios, antes que esperar la mano larga de la justicia estatal.

\section{Incivilidad, pasado y futuro:}

Pero no podemos crear más desesperanza y no futuro del que ya nos muestra este panorama. Si bien la principal meta de la modernidad humana fue la erradicación de la violencia, sigue siendo una meta por lograr, un ideal que no ha sido realizada aún en ninguna sociedad por civilizada que parezca. "Para decirlo con 
mayor claridad: en todas las formas conocidas de sociedad civil existen fuentes endógenas de incivilidad". Como lo afirma taxativamente John Keane:

[...] La incivilidad es un aspecto crónico de las sociedades civiles, una de sus condiciones características y, por tanto, hablando en términos normativos, un continuo obstáculo para la consecución de una sociedad plenamente "civilizada. (59)

No obstante, la historia nos muestra un horizonte amplio. La incertidumbre en el presente y el futuro no puede hacernos idealizar el pasado. No todo pasado fue mejor y así lo fuera, el pasado ya no está. Las violencias de los siglos anteriores no eran deseables frente a las del presente. Si bien ha habido un deterioro coyuntural del tejido de la sociedad no queda otro camino que hacer más humana la humanidad:

[...] Con todo, la idea básica en las palabras del filósofo, es decir, el hecho de que la violencia sirva para instrumentalizar a sujetos hablantes y relacionados entre sí conserva todo su interés. Por repetirlo en un lenguaje que quizá él no habría comprendido, una sociedad civil protegida y sostenida por instituciones responsables supone la existencia de sujetos hablantes que se relacionan pacíficamente; por tanto, la finalidad (temporal, al menos) de la violencia es enmudecerlos, y a veces conducirlos en manada al cubil de la muerte. (63)

Solidario para que el sujeto sea consciente de las relaciones que construye, desde sus simples palabras hasta los grades acciones, lo cual nos es fácil. Es un trabajo que en todos los espacios y el punto de partida puede ser otra vez la escuela, la familia y la ciudad, representada en el barrio.

El Estado moderno se construyó desde arriba hacia abajo. Grandes revoluciones que derrocaron los Estados del antiguo régimen monárquico y colonial regularon las estructuras de la sociedad pero en dos siglos solo lograron diseñar una arquitectura de respuesta a los grandes problemas. Demoraron varias décadas para solucionar el problema de la esclavitud y más de siglo y medio para entender los derechos de las mujeres, los niños y las niñas, y de la amplia población negra e indígena y aún así muchos derechos no tienen plena vigencia. Ahora la tarea tal vez sea, construir un Estado desde abajo, desde los problemas de la vida cotidiana, desde las pequeñas comunidades. El mundo globalizado es predominantemente urbano en tanto que en los tiempos del diseño del Estado Nación era un mundo poderosamente rural: el poder era la tierra y el territorio estaba 
ligado a ella; la sociedad del siglo XXI tiene nociones territoriales distintas, sus escenarios son virtuales y simbólicos y las relaciones del poder y el deber se han replanteado. Las relaciones que expliquen estos cambios deben ser repensadas. Pero las relaciones primordiales siguen siendo entre seres humanos. Entre hombres y mujeres. El siglo XXI puede ser el espacio para una nueva noción de "sociedad civil".

\section{La violencia ¿anomia o problema ético?}

Numerosos estudios sociales sobre los problemas de la violencia recientemente han vuelto a apelar a un viejo concepto con el que surgió en Francia la Sociología, en el siglo XIX: analizar las expresiones de violencia como una situación anómica. El concepto fue creado por Emile Durkheim y literalmente significa ausencia de normas. Una situación social anómica se da cuando los integrantes de una sociedad no se rigen por las normas establecidas, lo que hacen que dichas normas se desvirtúen o degraden. Está asociado al decaimiento de la sociedad como constructora de consensos normativos, el rompimiento de la solidaridad social, como lo plantea el famoso sociólogo francés en La división del trabajo social (Durkheim, 1982),

Robert K Merton posteriormente realiza un nuevo desarrollo del concepto en Teoría y estructura sociales, estableciendo cinco tipos: 1) Conformismo, 2) Ritualismo, abandono las metas del éxito y de la movilidad social. 3) Rebelión, cuando no se aceptan ni las normas ni los fines. 4) La innovación, cuando se buscan los fines pero no se aceptan las normas. 5) Retraimiento, cuando no se aceptan las metas culturales ni los medios institucionales y se adoptan mecanismos de escape. (Merton, 1980: 140)

Muchos de estos trabajos miran la violencia como un problema de funcionalidad del orden, de "conducta desviada" lo cual es importante, pero no basta. Hay que trascender el análisis "técnico" del funcionamiento de las normas y entrar en el terreno difícil de la dimensión ética. El problema de los medios y los fines es un problema no solamente jurídico, o sociológico o criminológico. Importantes estudios han enfatizado en la mirada ética, abriendo un debate necesario como en El mundo de la violencia:

[...] En su especificidad, y vista en sí misma, la violencia tiene todos los rasgos de un fenómeno axiológicamente negativo. Corresponde a la hybris, la 
desmesura, la fuerza desencadenada que los griegos consideraron peligro demoniaco. La violencia es el terror, como quiera que éste se manifieste. Implica claudicar de los medios y fines humanos no violentos: retorno a fuerzas impulsivas, irracionales y premorales. Es regresión histórica y ética, forma de radical desesperanza y desesperación. (Sánchez Vásquez, 1998: 140)

La violencia se ha convertido en un recurso fácil. La política marcó el camino de los medios para alcanzar los fines justos, cayendo en el pragmatismo de los fines eficientes y rápidos para lograr un fin. El capitalismo sin normas, que aboga por la desregulación y la libre empresa adoptó el mismo pragmatismo y las conductas de los individuos y los colectivos. Hoy los problemas relacionados con la muerte de los otros, el daño irreversible a los individuos y colectivos que se oponen a la obtención de determinados fines, son el centro del debate de la sociedad global, como lo ha sido en todo el período moderno desde la era de las revoluciones. Una frase de Marx ha hecho correr ríos de tinta "La violencia es la partera de la historia". Sin embargo la frase nunca ha sido tomada en su contexto. La frase textual de Marx no es una apología es una constatación: la usa en el contexto de la explicación de la "acumulación originaria del capital, donde la violencia jugó un papel fundamental para la formación de los Estados nacionales y mediante el uso del colonialismo como forma de aceleración del proceso. "La violencia es la comadrona de toda sociedad vieja que lleva en sus entrañas otra nueva". En varias ocasiones Engels y Marx matizaron esta expresión, que ha sido usada de miles de formas para deformar su intención inicial. Lo cierto es que bajo cualquier pretexto la violencia se ha unido inseparablemente a la política. Otra tergiversación parecida tiene que ver con la frase "la violencia es el motor de la historia", que también se atribuye a Marx. La frase original es "La lucha de clases es el motor de la historia" que tiene un sentido totalmente distinto. La lucha política no necesariamente es violenta. Precisamente la política se hizo para eliminar la guerra, es decir, la violencia, y los mecanismos de la democracia se hicieron para erradicar definitivamente de la sociedad a la violencia. Lo que sucede es que los intereses hacen inviable los métodos de la política y más los de la democracia. Sin embargo la era de las revoluciones, decíamos, la fundación de las repúblicas y la destrucción del antiguo régimen colocaron en el centro el uso de la violencia.

Joxe Iriarte, uno de los críticos de la violencia europea plantea:

[...] De hecho, salvo el pacifismo extremo, partidario de ofrecer la otra mejilla —e incluso éste admite excepciones - ninguna doctrina filosófica, 
y mucho menos política, rechaza el empleo de la violencia, sea ésta en primera o última instancia. De los Estados está todo dicho. La Constitución americana defiende el derecho del ciudadano a levantarse en armas contra la tiranía, y ninguna organización o movimiento revolucionario que aspire a cambiar la sociedad excluirá el enfrentamiento armado, pues sabe que tarde o temprano los que están en el poder sacarán los tanques a la calle (Iriarte, 2011).

Cada vez las implicaciones éticas del uso de la violencia, desde cualquier lugar, incluido los Estados más legítimos, y las causas más justas, tiene más falta de consenso y más aristas de debate. Véase por ejemplo el atolladero de la toma y retoma de Palacio de Justicia en Bogotá en 1985, o cualquier acción destacada de cualquier Estado donde se haya usado a fondo la violencia o las contraviolencias que ella desata.

Keane plantea al respecto una reflexión práctica interesante:

[...] La máxima más eficaz en materia de violencia podría ser la siguiente: la decisión de recurrir o no a la violencia en lo relacionado con el poder o la política, tanto en el seno de una familia como en el campo de la batalla, resulta siempre arriesgada, porque tiene consecuencias imprevistas, entre las que cabe esperar algunas que contradigan el objetivo para el que la violencia se había considerado un medio eficaz o efectivo. Los juicios sobre la utilidad y la ética de la violencia son, pues, necesarios. Y es así porque en materia de violencia los defensores de la sociedad civil deben saber que normalmente-no siempre-aquélla [la violencia] contradice y destruye la civilidad (Keane, 2000: 82).

La dificultad práctica de este tipo de postulados filosóficos es que la violencia, aunque está dominada por las racionalidades de todo tipo, cuando se desata se convierte en una máquina mutante cuyas intensiones iniciales, buenas o malas, terminan siendo desbordadas por los hechos. Todas las reflexiones éticas quedan relativizadas muchas veces por circunstancias y argumentaciones justificatorias que rebasan muchas veces estas reflexiones. De ahí la afirmación de Max Weber: "No hay ética en el mundo capaz de eludir el hecho de que la consecución de un fin bueno nos obliga muchas veces a pagar un precio; es decir, a emplear medios peligrosos o de dudosa moral, y a contar con la posibilidad de que tengan ramificaciones malignas" (Keane, 2000: 13).

El caso colombiano es paradigmático. La violencia se usó y se usa para resolver todo tipo de conflictos. Las violencias inicialmente de las estrategias de la guerra 
civil se expandieron al resto de las actividades sociales por la vía de las economías ilegales y la tolerancia institucional a las conductas violentas con el fin de derrotar las insurgencias crónicas en que devino el fracaso revolucionario. Los ejércitos privados impusieron su lógica y el Estado fue rebasado en todas sus funciones por las lógicas de las violencias de los "buenos", de los defensores de la democracia, mientras que los luchadores por un "hombre nuevo" y por la revolución "justa" contra la ignominia y la opresión se transformaron en actores de una violencia sin límites, que se envolvió en sí misma sin mirar a los pobres que dicen defender. Entretanto la sociedad civil se llenó de armas y motivos para matar y para mandar matar, desvirtuándose radicalmente y convirtiéndose en generadora de violencias tan crueles, dolorosas e inútiles, con períodos y situaciones seguramente aproximados a la "anomia social".

Es en este contexto que tenemos que mirar las violencias "de la calle" y de la escuela, articuladas con las violencias de la familia. Porque allí los hechos de violencia son menos reflexivos, más emocionales e impulsivos. Obedecen a criterios más individuales o a pequeños colectivos menos autorregulados por este tipo de reflexiones. 



\section{La ciudad latinoamericana: economía, sociedad y juventud}

...La humanidad, renovando de generación en generación su activa esperanza y su ansiosa fe en un ideal, a través de la dura experiencia de los siglos... la humanidad viste otra vez sus galas nupciales para esperar la realidad del ideal soñado con nueva fe, con tenaz y conmovedora locura. Provocar esa renovación, inalterable como un ritmo de la Naturaleza, es en todos los tiempos la función y la obra de la juventud. De las almas de cada primavera humana está tejido aquel tocado de novia...

Motivos de Proteo, José Enrique Rodó

En el momento que vive el mundo, la juventud es una fuerza fundamental del desarrollo, especialmente en sociedades jóvenes como las de América Latina. Como nunca, la población juvenil tiene en promedio más años de educación que los miembros de generaciones anteriores y tienen el dominio casi monopólico del acceso a nuevas tecnologías, especialmente las de las comunicaciones, la información y el conocimiento. Son ellos los que más necesitan y demandan acceso a educación, salud y empleo, pero también al más escaso de los bienes, la vivienda digna distinta a la de su familia de origen. Son los grupos poblacionales de mayor movilidad, que pueden cambiar de lugar, empleo y trayectoria de vida, pueden ir por el mundo buscando nichos de oportunidades y según estudios, destinados en el siglo XXI a cambiar varias veces de profesión. Son los grupos etarios más saludables, pues se enferman menos y tienen cada vez mayor esperanza de vida y están más dispuestos a asumir los cambios, más resilientes, en el sentido de representar la capacidad humana de asumir con flexibilidad situaciones límite y sobreponerse a ellas. En términos generales, el panorama podría ser muy optimista.

Sin embargo, también, los jóvenes y adolescentes entre los 12 y los 24 años son los más expuestos a situaciones de violencia, al suicidio, al maltrato escolar, abuso sexual, maltratos en la familia, entre hermanos, a ser reclutados por organizaciones armadas, legales e ilegales, al pandillismo y a los consumos, entre otros riesgos sociales. Es la población que más sufre con el desempleo y con las ineficiencias del sistema educativo. Son de alguna forma, la población de más alto riesgo social y en mayor situación de vulnerabilidad en el sentido de estar más expuestos a situaciones de violencia que los demás grupos etáreos.

Esta parte de nuestro trabajo hará un contexto de lo social, de los pros y los contras de las realidades de las sociedades colombiana y latinoamericana y las situaciones estructurales y coyunturales que contribuyen a explicar las situaciones que facilitan o propician situaciones de violencia y en especial aquellas que 
nos permiten analizar sociológicamente las violencias relacionadas con la vida escolar con miras a la acción preventiva. No queremos poner un tono apocalíptico, sin embargo estas realidades deben ser tratadas sin eufemismos para que los lectores puedan tener claras las situaciones a que se enfrenta la sociedad del siglo XXI, que en estos aspectos están lejos de ser promisorias y por el contrario preocupantes, cuando se trata de niños, niñas, adolescentes y jóvenes: es decir del futuro de la humanidad que crece en las escuelas.

\section{América Latina: estructuras que facilitan lo violento}

Estudios recientes sobre el tema de la ciudad latinoamericana contemporánea ubican como los principales problemas de carácter estructural que ayudan a explicar los fenómenos violentos, los siguientes: la exclusión social, la pobreza, la discriminación y la informalidad ${ }^{13}$; presencia de actores residuales que han emergido en décadas anteriores y luego de terminados los conflictos armados internos, lo cual facilita el surgimiento de bandas, las pandillas y las maras; la corrupción, principal peligro de las democracias y de cualquier estado contemporáneo, máxime si las mafias y las organizaciones criminales han tenido o tienen acceso al gobierno; la situación generalizada de impunidad, entre otros.

\section{Exclusión, pobreza, discriminación e informalidad}

Este podría ser el resumen de los pecados capitales del modelo de desarrollo latinoamericano, sumado a su inmediata consecuencia: desigualdad e inequidad, que se refleja en todos los aspectos de la vida corriente:

[...] La exclusión social, la pobreza, la discriminación y la informalidad; según la organización Internacional del Trabajo, casi uno de cada dos trabajadores urbanos latinoamericanos son informales y constituyen un terreno fértil para las actividades ilícitas. En particular, existe una fuerte presión migratoria que nutre las redes transnacionales de tráfico de personas. De igual manera, la concentración socio-espacial de la pobreza y la informalidad del fenómeno de la "ciudad dividida" están muy relacionadas con la violencia urbana (Mesa, 2006: 211).

La exclusión social, la pobreza, la discriminación y la informalidad, son esferas de un mismo círculo que se retroalimentan, en la medida en que la sociedad ur-

13. Nos referimos en especial a Manuela Mesa en su artículo "Violencia social y globalización en América Latina", (Mesa, 2006: 211). 
bana no crea mecanismos de inclusión. La ausencia de "inserción estable" en el mundo laboral crea las condiciones para la trashumancia que hace vulnerables a todas las personas pero especialmente a los jóvenes. El deseo de cambiar su condición de ascender socialmente permite que muchos, hombres y mujeres, pierdan la paciencia sobre los mecanismos tradicionales para "surgir". Pero estructuralmente el mundo del trabajo regido por el marco general de las relaciones sociales que vivimos, no permite que muchos — la mayoría-, de los jóvenes que ingresan al sistema laboral, lo hagan en condiciones dignas, para encausar su proyecto de vida. La gran mayoría de jóvenes sabe que les espera un destino de discriminación e informalidad.

\section{Actores residuales de las guerras}

El otro factor que afecta a muchas ciudades latinoamericanas, es la frecuencia con la que diversos actores armados que han emergido en décadas anteriores y que luego de terminadas dichas guerras, o sin terminar, como en el caso colombiano, deben insertarse en la vida urbana, muchas veces sin las presencia institucional y las condiciones de vida necesarias para que no apelen a formas ilegales de vida:

[...] Existe una relación entre el surgimiento de los actores armados en América Latina y la debilidad de las instituciones, que se traduce en vacíos locales de gobierno. En las barriadas y favelas de las grandes ciudades latinoamericanas, estos vacíos se forman a raíz de una prolongada ausencia de las autoridades y de los representantes de la ley. A menudo, los actores armados privados e informales ocupan el lugar de la policía y la justicia... La ausencia de la autoridad se explica por la debilidad de las instituciones públicas, pero las bandas armadas la imponen por la fuerza, pues es un requisito para poder desarrollar su actividad delictiva, generalmente asociada al narcotráfico. (211)

Las bandas, las pandillas y las maras encontraron un territorio fácil de dominar ante la ausencia de agentes estatales. De otra parte las redes del micro-tráfico y cobro de vacunas y extorciones se convirtieron en fácil mecanismo para no depender de la economía del trabajo. Por el contrario, muchos jóvenes ahora tendrán poder y serán importantes, ganándose un lugar que la ciudad les negó.

Otro factor asociado a las causas estructurales de las violencias urbanas en América Latina, tiene que ver con la presencia de conflictos armados internos 
de relativamente larga duración, cuyos efectos permanecen por largos periodos en el tiempo:

[...] las prolongadas guerras civiles de los países centroamericanos y andinos han dejado un legado de violencia y criminalidad y un gran número de armas de guerra ahora utilizadas para actividades delictivas. Los actuales responsables de la violencia son en muchos casos actores no estatales que operan en enclaves urbanos pobres y marginales, en ocasiones surgidos de procesos de desmovilización de las fuerzas armadas, los paramilitares y los grupos guerrilleros. Empero, también emergen bandas criminales que han logrado tener el monopolio de la violencia (ilegítimo a ojos del Estado, legítimo a ojos de ciertos sectores sociales) en países como Colombia, Guatemala y México y en un sentido más restringido, en Argentina, Brasil, El Salvador, Honduras y Perú. (227)

La guerra enseñó una forma de vida donde la principal característica es que se aprendió un oficio, se perdió el miedo a morir o matar y se adquirieron "destrezas" que son difíciles de adquirir en un mercado ilegal. La formación de un guerrero o un sicario toma mucho tiempo y no existen muchas escuelas especializadas a la vuelta de la esquina. Además se tuvo el contacto con las redes del negocio de las armas que quedaron después de la desmovilización en el mercado ilegal. A juzgar por las consecuencias, la reinserción es más riesgosa que la misma guerra, máxime, como en el caso colombiano, cuando la guerra no ha terminado. O dicho de otra manera: una paz mal hecha es tan mala como la guerra misma. Las posguerras son un camino de grandes dificultades donde se ve que las secuelas de la guerra no terminan cuando llega la paz. La elevación de la delincuencia urbana en Colombia, el rearme de la llamadas "bandas emergentes", la reconstitución de los ejércitos narco paramilitares, aunque ya no tiene la misma fuerza, es una realidad con la que la ciudad colombiana tiene que convivir. En el caso de Bogotá, los desmovilizados ${ }^{14}$.

\section{Corrupción, mafias y permeabilidad ilegal}

La corrupción es un factor que coadyuva indirectamente en las relaciones de violencia. Es la forma como muchos neutralizan la acción de la justicia y el Estado. Los que más ganan son los agentes del crimen organizado en sus acciones para debilitar el Estado de derecho e impedir que los gobiernos puedan promover y

14. En uno de los planteles con altos indicadores de violencia de este estudio, en la Localidad de Fontibón, nos encontramos con la presencia de cerca de 50 estudiantes reinsertados de las AUC. Según la Alta Consejería para la Reintegración, entre agosto de 2002 y octubre de 2009, 51.992 personas se desmovilizaron (individual y colectivamente). El 61\% producto de las negociaciones de paz con las Autodefensas ilegales. Muchos de ellos están en la ciudad de Bogotá. 
proteger los derechos humanos y en general la defensa del interés público ${ }^{15}$. El caso colombiano en este campo sigue siendo paradigmático, pues es producto de un modelo de contrainsurgencia continental que se salió de cause. Un editorial de El Tiempo, titulado Paras a paso grande, principal periódico colombiano afirma:

[...] La magnitud del control que han adquirido los grupos paramilitares sobre extensas regiones del país se ha convertido en un fenómeno dramático, con preocupantes implicaciones para el futuro nacional. Las autodefensas exhiben hoy una influencia que no es solo militar sino política, social, y económica. Tan profunda y tan extendida, que para muchos no resulta exagerado hablar de una progresiva paramilitarización de Colombia". (El Tiempo, 25 de septiembre de 2004: Editorial)

¿Pero cómo se llegó allí? En primer lugar es el único conflicto armado interno activo en el continente y el más largo. No hay que olvidar que la primera guerrilla se formó a raíz del 9 de abril 1948 con el asesinato del líder liberal Jorge Eliecer Gaitán y han venido formándose generaciones de guerrillas en los años cincuenta, sesenta y setenta. Algunas de ellas se relanzaron en la década de los años 80 del siglo XX. A partir de 1990, aunque hubo una negociación con algunas guerrillas ${ }^{16}$, el fracaso de una década de intentos de negociación fue paralelo al crecimiento del paramilitarismo, el genocidio del partido que se creó para el primer proceso de paz de los años ochenta con el Presidente Belisario Betancur (la Unión Patriótica) y la persecución a los sindicalistas y activistas o defensores de derechos humanos. El mismo editorial del diario El Tiempo tiene su respuesta:

\section{[...] Ha sido largo el camino recorrido desde San Juan Bosco Laverde y Puerto Boyacá, en 1982, hasta Santa Fe de Ralito hoy", decía Mancuso en la instalación de los diálogos de Ralito y añadía que "nunca estuvo en nuestras mentes edificar este gigante". Pero lo cierto es que este enorme monstruo de mil cabezas hoy avanza a paso grande, atropellado y voraz por todo el territorio nacional. Con múltiples vasos comunicantes con pode-}

15. Recientemente fue publicado un informe que puede ser la clave de uno de los casos de impunidad más graves de toda la historia de América: Memoria de la impunidad en Antioquia, donde el IPC y la Corporación Jurídica Libertad decidieron recopilar "lo que la justicia no quiso ver frente al paramilitarismo". De otra parte la Corporación Nuevo Arco Iris ha publicado informes sobre varias regiones que han comprometido los procesos electorales de muchos dignatarios electos por voto popular demostrando su relación con grupos armados. Equipo Interdisciplinario Sobre Impunidad y Memoria. Memoria de la impunidad en Antioquia. (2010) Lo que la justicia no quiso ver frente al paramilitarismo. Colombia: Instituto popular de capacitación, Corporación jurídica libertad.

16. En 1990 las únicas negociaciones con las guerrillas del Movimiento 19 de abril, M-19, un sector del Ejército Popular de Liberación, EPL, La corriente de Renovación Socialista, una disidencia al interior del ELN y el Movimiento Indigenista Quintín Lame. 
res locales, civiles o militares, sectores económicos y la política nacional. Y con capacidad de incidencia sobre presupuestos y autoridades municipales. Respaldado por fantásticas cantidades de dinero provenientes de la captura de toda clase de rentas legales e ilegales, desde los dineros de la salud hasta el narcotráfico, pasando por la gasolina y el boleteo generalizado. Con un poder de fuego e intimidación que ha desplazado a la guerrilla de muchas regiones y producido decenas de miles de desplazados y cientos de masacres y asesinatos selectivos. (El Tiempo, Editorial, 2004).

Pero aun en el marco de la excepcionalidad colombiana, aunque en menor proporción, muchos países de la región viven el problema de alguna manera. La institucionalidad tiene serios problemas de funcionamiento y legitimidad, sobre todo en el campo de las autoridades de justicia y policía:

[...] hay que mencionar la ineficacia y la corrupción que minan a las fuerzas policiales y al poder judicial. Para muchos latinoamericanos, la policía no sólo no puede impedir la violencia urbana, sino que es parte del problema, porque con frecuencia es abusiva, incompetente, corrupta o está implicada en los secuestros o en el narcotráfico... Esta percepción negativa de las fuerzas del orden se debe al legado de las dictaduras, que militarizaron a la policía y la orientaron a funciones contrainsurgentes y de mantenimiento del orden interno. (Mesa, 2006: 211)

La corrupción es el principal peligro de las democracias y de cualquier estado contemporáneo. Máxime si las mafias y las organizaciones criminales han tenido o tiene acceso al gobierno. Y este lamentablemente es el escenario más negativo en muchos países latinoamericanos. Algunas economías ilegales han llegado a controlar el poder local y regional. El caso colombiano, que no es diferente que el de otros países, hasta ahora asoma su cara oscura. Cerca del $30 \%$ del parlamento ha tenido algún tipo de proceso penal o disciplinario. Instituciones completas han tenido que ser reestructuradas y mientras se escribe este informe el principal organismo de seguridad dependiente del ejecutivo está siendo acusado de usar su poder ilegalmente y de haber trabajado en cooperación con grupos del narco paramilitarismo. En varias regiones en guerra las instituciones locales fueron copadas por poderes mafiosos e incluso hubo zonas donde varios grupos de guerrillas o paramilitares se enfrentaron en pequeñas guerras por los recursos del Estado.

A lo anterior se suma que las prioridades están distorsionadas. La presión internacional para obtener ayuda exige resultados. Perú y Colombia han recibido ayuda estadounidense para la guerra contra las drogas, y que dicho sea de 
paso, es reconocido como uno de los fracasos más rotundos de la política internacional de los últimos años, con efectos perversos y múltiples. En el caso colombiano es evidente: en la lucha contra "el narcoterrorismo" se pasó de gasto en la guerra de 2.0 de PIB en el 2002 a 3.8 en el 2010. Dicha guerra solo explica del $5 \%$ al $20 \%$ de las muertes violentas al año. En tanto la criminalidad urbana y las violencias urbanas que producen el más alto porcentaje de homicidios no recibe la atención ni la inversión social necesaria para contrarrestarla.

\section{Impunidad e inseguridad}

Otro de los factores que se anotan es la situación generalizada de impunidad. El sistema carcelario es totalmente inefectivo en sus fines de rehabilitación y es sabido que las cárceles son escuelas del delito y oficinas de "managers" o gerentes para la comisión de nuevos delitos desde la misma cárcel. Pero lo más sorprendente es el tiempo de duración de los procesos y que más del $50 \%$ de los reos, están en calidad de detención previa al juicio. Los índices de impunidad y sub registro de los homicidios son similares en toda la región. México, Brasil, Guatemala 96\%, Colombia 97\%.

En términos generales, la probabilidad de condena por un delito en Colombia no supera el $20 \%$. En materia de homicidio tal probabilidad gira en torno al $3 \%$. La Fiscalía colombiana registró 62.737 noticias criminales e igualmente registró 1.699 sentencias condenatorias. Es pertinente destacar que este $3 \%$ es un porcentaje ligeramente inferior al que muestran las cifras del sistema penal anterior, luego de una reforma sustancial al sistema judicial y al sistema acusatorio como lo refiere Barreto Nieto y Rivera en Un mirada a la impunidad en el sistema penal acusatorio en Colombia (2009).

El círculo vicioso del estigma de las comunidades pobres es secular: las autoridades invierten poco o nada en la protección de los barrios marginales, a pesar de que se sabe que en estas zonas los pobladores tienen más probabilidades de ser víctimas de delitos y actos violentos. Al no invertir en seguridad ni desarrollo social en las zonas inseguras, que es donde más se necesita, a largo plazo se agudiza el problema y cuando este se desborda, la solución es represiva, con el argumento de que son territorio del delito, lo que "criminaliza" de hecho aun más a estas comunidades.

Muchas veces las respuestas son fragmentarias o equivocadas. Está de moda copar militar o policialmente estas barriadas, produciendo ataques indiscrimina- 
dos contra la población, ejerciendo excesos y violaciones a los derechos de los no delincuentes, (y de los delincuentes). O hacer campañas esporádicas que no constituyen solución alguna o que se traduce en programas asistencialistas. La otra tentación tanto de las autoridades como de las comunidades es la conformación de grupos de autodefensa que terminan tomándose la justicia por propia mano ${ }^{17}$.

\section{La coyuntura y la crisis mundial: América Latina en alto riesgo social}

Un rápido diagnóstico de las consecuencias de la crisis económica que afecta coyunturalmente al sistema-mundo del capitalismo posmoderno nos puede servir para comprender las condiciones estructurales y coyunturales de la forma como las realidades socio-económicas latinoamericanas inciden en el deterioro de las condiciones de vida de la población usuaria del sistema escolar público y privado.

A partir del 2011-2012, según proyecciones económicas de los expertos, se van a agravar las condiciones sociales de América Latina, hasta el punto de colocarla en situación de "alto riesgo social"18. Los posibles efectos sociales de la crisis podrían ser: aumento del desempleo en general, y en especial femenino y juvenil, elevación de los índices de pobreza, disminución de la cobertura en salud y protección social. En cuanto a la educación se prevé el aumento de riesgo en deserción escolar, aumento de los círculos viciosos y de las llamadas "trampas de pobreza". Veamos en detalle algunos de esos aspectos.

Aumento de las tasas de desempleo: La tasa de desempleo urbano crecería, según cifras proyectadas de la OIT, hasta acercarse a dos dígitos ${ }^{19}$ lo que aproxi-

17. Para no ir tan lejos, en los barrios de todas las cinco localidades donde se realizó esta investigación, se encontró algún tipo de amenaza y evidencias de amenaza de limpieza social, como panfletos o informaciones de acciones similares contra la delincuencia menor. En al menos una Localidad, el equipo percibió que miembros de la comunidad y líderes activistas cívicos que colaboraron con la investigación de campo, han participado y comparten la filosofía de dichas campañas de limpieza.

18. El siguiente aparte se basa en: Kliksberg, Bernardo. América Latina: alto riesgo social. El País. [En línea] España, Madrid, 24, junio, 2009. Kliksberg es economista y asesor de Gobiernos y organizaciones internacionales, es coautor junto al premio Nobel Amartya Sen del libro Primero la gente (Deusto, 2008). El autor se basa en cifras de Banco Mundial, CEPAL, OIT y UNESCO.

19. Colombia Tasa de desempleo. [Consultado 13 julio 2011]. Disponible en: <http://www.indexmundi. com/es/colombia/tasa_de_desempleo.html> Fuente: CIA World Factbook - A menos que sea indicado, toda la información en esta página es correcta hasta el 11 de marzo de 2011. Los datos son provenientes de fuentes oficiales del DANE. 
maría las cifras a los 20 millones de trabajadores sin empleo, lo cual agravaría aún más las tensiones sociales. El más grave será el desempleo juvenil y si tenemos en cuenta que la tasa de jóvenes desempleados duplica actualmente la tasa de desempleo total, siendo Colombia uno de los países más críticos donde los desempleados jóvenes son 978.000 , equivalente al $50 \%$ del total nacional.

En general en América Latina uno de cada cuatro jóvenes está fuera del mercado laboral y la mayoría de ellos también del sistema educativo. En la medida en que se agudiza la situación laboral, están siendo expulsados los jóvenes, los pobres y los de menos educación y capacitación. Los profesionales jóvenes están asumiendo oficios para trabajadores no calificados o están condenados al desempleo crónico. Hay que recordar que el principal detonante de la crisis concatenada del 2011 en los países árabes y en general el movimiento europeo de los Indignados fue el desempleo juvenil. En Colombia, hace cerca de una década se desbordaron críticamente las cifras de desempleo, sobrepasando de manera crónica o estructural la barrera de los dos dígitos, como lo demuestra el siguiente cuadro de la evolución de la tasa general de desempleo. Si las proyecciones son de aumento de las tasas generales de desocupación laboral, la situación puede bordear situaciones límite:

Cuadro 1. Colombia: Tasa de desempleo 2003-2010

\begin{tabular}{|c|c|c|c|c|}
\hline Año & $\begin{array}{c}\text { Tasa de } \\
\text { desempleo }\end{array}$ & Posición & $\begin{array}{c}\text { Cambio } \\
\text { Porcentual }\end{array}$ & $\begin{array}{c}\text { Fecha de la } \\
\text { Información }\end{array}$ \\
\hline 2003 & $17,40 \%$ & 58 & & 2002 est. \\
\hline 2004 & $14,20 \%$ & 72 & $-18,39 \%$ & 2003 est. \\
\hline 2005 & $13,60 \%$ & 121 & $-4,23 \%$ & 2004 est. \\
\hline 2006 & $11,80 \%$ & 119 & $-13,24 \%$ & 2005 est. \\
\hline 2007 & $11,10 \%$ & 124 & $-5,93 \%$ & 2006 est. \\
\hline 2008 & $11,20 \%$ & 129 & $0,90 \%$ & 2007 est. \\
\hline 2009 & $11,30 \%$ & 132 & $0,89 \%$ & 2008 est. \\
\hline 2010 & $12,00 \%$ & 132 & $6,19 \%$ & 2009 est. \\
\hline 2011 & $11,80 \%$ & 123 & $-1,67 \%$ & 2010 est. \\
\hline
\end{tabular}

Fuente: Colombia Tasa de desempleo. [Consultado 13 julio 2011]. Disponible en: <http://www. indexmundi.com/es/colombia/tasa_de_desempleo.html> 
Mayor discriminación laboral femenina: Según la OIT, por sexo, Colombia es uno de los países con mayor índice de desocupación entre las mujeres (14,8 por ciento) y solo es superada por Jamaica (16,7 por ciento) y República Dominicana (21,9 por ciento). En el 2010 el desempleo afecta a 16.9 millones de mujeres y hombres lo que representa una gran brecha de trabajo decente. Se estima que la tasa de desempleo promedio anual de 2010 será $7.4 \%$, es decir, 0.7 puntos porcentuales menos del $8.1 \%$ de 2009 . Esto significa que el crecimiento económico generó empleo u ocupación para cerca de 1.2 millones de personas y el desempleo afecta en el 2010 a 16.9 millones de hombres y mujeres en América Latina y el Caribe. Lo cual quiere decir que Colombia está 4 ó 5 puntos porcentuales por encima del promedio latinoamericano (OIT. Panorama Laboral 2010).

Pero no es una situación nueva. Antes de la crisis, en el 2006, en América Latina las mujeres sobrepasaban la tasa de desempleo masculina en un 56\% en tanto que sus ingresos eran inferiores en un $72 \%$ que el de los hombres. En un escenario de mayor desempleo, las familias de mujeres cabeza de familia, que alcanzan el $33 \%$ del total y un gran porcentaje para las cuales el empleo femenino es vital para la manutención y equilibrio doméstico, tendrán situaciones económicas muy difíciles, colocando en dificultades no solo a ellas sino a sus hijos, muchos de los cuales en épocas de desempleo femenino deben abandonar la escuela. La CEPAL estima que sin el trabajo femenino estable la situación de pobreza podría aumentar en un $10 \%$ en la región.

Pero además del desempleo, preocupa la calidad de los puestos de trabajo. El mencionado informe de la OIT señala que en 5 países de la región (Colombia, Ecuador, México, Perú y Panamá) no obstante la formalización de los contratos, el empleo en el sector informal siguió creciendo a un ritmo mayor, si se compara el segundo trimestre de 2010 con el mismo de 2009. Es decir, que estamos ante un fenómeno dual. De una parte, crece el empleo formal (en 4.6\%) lo cual es un signo positivo. Pero en dirección contraria, con mayor fuerza aumentó el empleo informal de baja calidad (en 7.2\%), fenómeno que afectó más fuertemente a las mujeres (9.9\%) en tanto que en los hombres fue de $(5.3 \%)$ y "las mujeres muestran una inserción laboral más precaria en las actividades por cuenta propia, como trabajadoras familiares auxiliares y en el servicio doméstico, donde las condiciones de protección social y de ingresos suelen ser más adversas" en los cinco países mencionados. (OIT. Panorama laboral, 2010: 14)

En ese sentido ni la situación ni la tendencia es favorable para este grupo de países donde está Colombia; según este estudio: "El empleo informal total afectaba en 2010 al $53.8 \%$ de los trabajadores en los países citados (contra el 53.6\% 
en 2009) y en el año más reciente el $50.9 \%$ de los hombres y el $57.6 \%$ de las mujeres sólo accedían a un empleo informal" (15).

No es para nada positivo el hecho de que las mujeres, muchas de ellas en alto porcentaje único o principal sostén de la familia, estén casi en el $60 \%$ de empleos de baja calidad y sin garantías.

Aumento de la violencia intrafamiliar: En crisis recientes en países de la región se ha detectado un incremento de las de por sí altas tasas de violencia intrafamiliar, que en algunos países alcanzan la escandalosa cifra del 38\%. Para muchas familias estas circunstancias pueden desatar situaciones insostenibles que terminan en situaciones conflictivas y violentas. La inestabilidad económica afecta no solamente la calidad y frecuencia de los ingresos de las familias sino que introduce tensiones que afectan la estabilidad y armonía.

En Colombia, la violencia intrafamiliar se asume como delito contra la armonía y la unidad familiar; por ello se expidió la ley 294 de 1996, que en desarrollo del artículo 42 de la Constitución Política de Colombia se formuló con el objeto de prevenir, remediar y sancionar la violencia intrafamiliar ${ }^{20}$.

La violencia intrafamiliar es además, como se afirma en Conflicto y violencia intrafamiliar una "respuesta inadecuada a tensiones y conflictos que desbordan la capacidad de respuesta de los individuos y el grupo, por encontrarse éstos en situación grave de limitación psicoemocional, sociocultural o económica". (Rubiano, 2003: 32)

Según el Documento del Centro de Referencia Nacional sobre Violencia, del Instituto Nacional de Medicina Legal y Ciencias Forenses, el grave fenómeno se expresa de diferentes formas: violencia conyugal, abuso sexual por algún integrante de la familia, violencia filio parental o maltrato a mayores, violencia paterno filial o maltrato infantil, violencia entre hermanos y violencia entre otros miembros de la familia. Dicho Instituto ha señalado la magnitud de esta problemática en Colombia. (Instituto Nacional de Medicina Legal y Ciencias Forenses, 1999). Entre los años 1997 a 2008 se evidencia el fenómeno tal y como se registra en la siguiente figura:

20. Colombia (16, julio, 1996). Ley 294 de 1996. Por la cual se desarrolla el artículo 42 de la Constitución Política y se dictan normas para prevenir, remediar y sancionar la violencia intrafamiliar. 


\section{Figura 6. Violencia Intrafamiliar en Colombia 19972008}

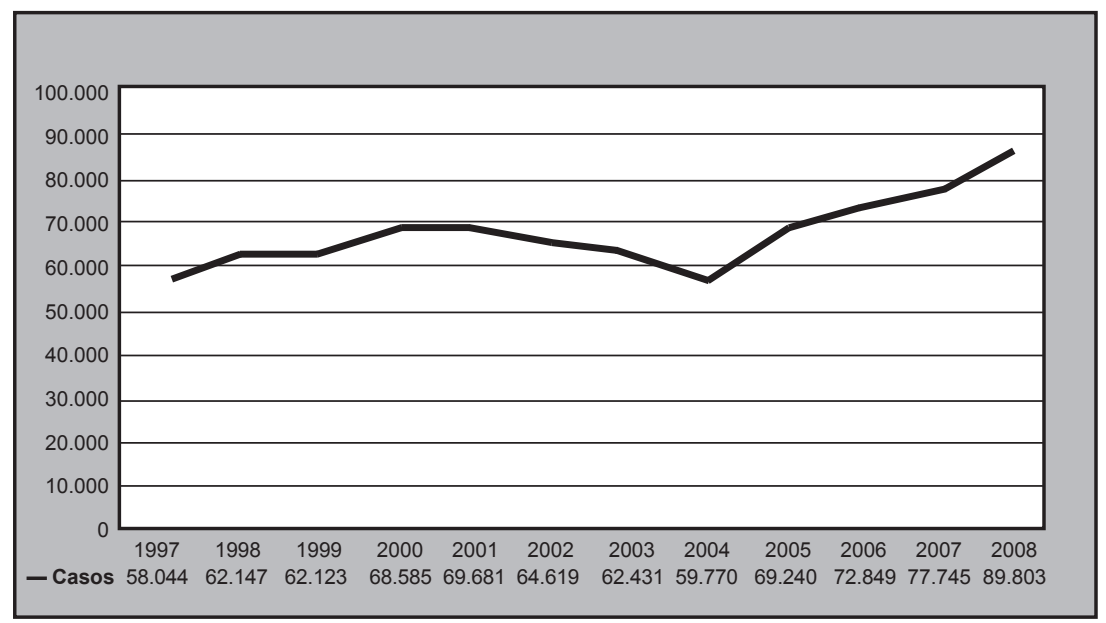

Fuente: Colombia. Instituto Nacional de Medicina Legal. Forensis 2008. Datos para la vida. Bogotá-Colombia.

En el caso particular de Bogotá, la situación de violencia intrafamiliar es similar al contexto nacional:

[...] 20\% de las mujeres en Bogotá ha sufrido algún tipo de violencia física y $35 \%$ violencia verbal. También son comunes las amenazas por parte de sus cónyuges como quitarle los hijos (22\%) y retirarle el apoyo económico $(18 \%)$. La violencia sexual ejercida en privado pone de relieve el ejercicio de relaciones de propiedad en la pareja: la violación es realizada por el cónyuge en un $11 \%$, por el ex marido en un $12.0 \%$ o por el novio en un $13 \%$. (PROFAMILIA, 2004).

[...] Durante el 2004 se realizaron 52.714 casos de violencia intrafamiliar, maltrato infantil y violencia sexual; dos de cada tres corresponden a mujeres. En 2005, en las Comisarías de Familia se reportaron 55.513 denuncias de violencia intrafamiliar, mostrando un incremento del $35 \%$ con respecto al 2003. (Jimeno, 2007: 10)

Aumento de las "trampas de la pobreza": En proyecciones del Banco Mundial, habría seis millones nuevos de pobres en América Latina para el 2009. Lo que hace que hayan aumentado las llamadas "Trampas de pobreza", es decir, círculos viciosos que generan situaciones que perpetúan la pobreza:

[...] Siendo niños de hogares pobres, deberán trabajar, abandonarán la escuela, sólo podrán acceder a empleos marginales, carecerán de protección 
social y reproducirán la pobreza. Un alto porcentaje de los niños nacidos en hogares donde sus padres no terminaron la primaria tampoco la finalizan. (Kliksberg, 2008).

Las desigualdades agudas de América Latina inciden en sus altos niveles de pobreza. Y a pesar de producir alimentos, los precios de los mismos hacen que existan 51 millones de personas desnutridas, especialmente entre la población infantil, cuya estadística alcanza el $16 \%$ de niños subalimentados.

Elevación de los Índices de Pobreza y Disminución de la Cobertura en Salud y Protección Social: En Latinoamérica el $40 \%$ de los trabajadores urbanos carece de servicios de salud y seguridad social; con el incremento del desempleo necesariamente incrementará el crecimiento del trabajo informal, aumentará la población vulnerable en mortalidad y morbilidad infantil, mortalidad materna, lo cual producirá un deterioro de la situación social, en términos generales. Pero el problema más ostensible es que las crisis económicas arrojan a importantes sectores de la población hacia la economía informal, siendo este el principal problema de la región, dado que esta población queda usualmente por fuera de la cobertura de seguridad en salud y pensión, agravando la situación de por sí, dramática.

Aumento de los riesgos en deserción escolar: Todos estos aspectos tiene una consecuencia directa sobre los niveles de educación básica: El aumento sistemático de la deserción. Actualmente hay 110 millones de personas que no terminaron la primaria y sólo la mitad de ellos termina la secundaria. El trabajo infantil es creciente y su incidencia es directa en la deserción escolar. Solo los jóvenes de mayores niveles educativos tendrán oportunidades de mejores empleos y un alto porcentaje de ellos están condenados de por vida a precarias oportunidades laborales.

El "efecto mariposa" en cadena hasta el eslabón más débil: la crisis del capitalismo global en sus manifestaciones específicas en América Latina cierra el círculo de sus "efecto mariposa" en cadena hasta el eslabón más débil: los niños y las niñas. No solo será la desescolarización, será el deterioro "sistémico" de su calidad de vida, de sus violencias intrafamiliares.

Aunque no tenemos una visión concluyente, pretendimos con este diagnóstico general de América Latina, mostrar como las condiciones socio-económicas estructural y coyunturalmente actúan sobre las relaciones sociales y sobre el deterioro de las condiciones de vida de la población infantil y juvenil y sobre las 
familias. Es así como estas condiciones de vida de la sociedad van construyendo un cuadro de deterioro de la vida especialmente urbana y la relación que estos factores tienen sobre la vida de los niños y los jóvenes en los barrios populares y en las escuelas, para mostrar como Bogotá y lo que pasa en sus localidades y barrios está inmersa en un contexto mundial y latinoamericano en condiciones muy similares. 


\title{
Sobre violencia urbana
}

"Si vas a salir a la calle, encomiéndate a Dios. Si no eres creyente, contrata guardaespaldas. Si eres creyente y tienes dinero, encomiéndate a Dios y contrata guardaespaldas".

"Notas sobre violencia urbana", Revista Letras Libres, Carlos Monsiváis

Las violencias escolares que estudiamos se dan en contextos urbanos, lo cual nos obliga a reflexionar sobre el fenómeno de la violencia en la ciudad contemporánea. La violencia urbana no es un tipo específico de violencia como tal. Es el conjunto de manifestaciones violentas que se dan en espacios urbanos. $Y$ aunque no hay una definición específica, todos los estudios hablan de una violencia especial que se desarrolla en las ciudades, de una alta concentración de delitos y de una permanente sensación de inseguridad de los ciudadanos. El ensayista Mexicano Carlos Monsiváis, sin ser un analista social, siendo un escritor de crítica cultural, la caracterizó así:

\begin{abstract}
[...] Los conflictos, las tragedias, las conductas límite propiciadas por la crisis del estado de derecho, el perpetuo estallido —económico, social y demográfico- de las ciudades, y la imposibilidad de una efectiva seguridad pública, ya sea por la ineficiencia de los cuerpos encargados o por la feudalización imperante en barrios y colonias. Violencia urbana es el amplio espectro de situaciones delincuenciales, ejercicios de supremacía machista, ignorancia y desprecio de los derechos humanos, tradiciones de indiferencia aterrada ante los desmanes, anarquía salvaje y desconocimiento de la norma. (Monsiváis, mayo de 1999)
\end{abstract}

Si miramos con detenimiento esta definición vemos que allí cabe todo tipo de hechos violentos y delincuenciales. Por eso la violencia urbana ha sido ante todo un concepto de la criminología más que de otras disciplinas. ¿Pero qué caracteriza a la ciudad contemporánea para que se haga tanto énfasis en las violencias urbanas? Una de las características más notorias de la ciudad es que por ser la principal aglomeración de la vida, se convierte en la mayor concentración de la muerte de variadas formas. Desde los accidentes de tránsito hasta los homicidios y suicidios de las más variadas formas. La otra característica es la participación de los jóvenes en hechos de violencia. Pero es una consecuencia lógica de los porcentajes de población entre los 15 y los 25 años, la forma como ellos se apropian del espacio urbano, la intensidad de las relaciones sociales, hacen que sean los que más interactúan por la ciudad y los que frecuentan horarios y situaciones de riesgo, lo que se tiene que reflejar estadísticamente. No olvidemos que la violencia es ante todo consecuencia de unas relaciones 
sociales en contextos específicos y las personas se relacionan cuando actúan e interactúan.

Después del final de la guerra fría los conflictos de América Latina cambiaron. Ya no son las guerrillas rurales y urbanas el fenómeno más notorio. Las guerrillas, que las hubo en casi todos los países de la región, desaparecieron gradualmente, algunas derrotadas como en los países que sucumbieron a las dictaduras, otras que negociaron procesos de paz, y solamente dos casos que lograron el triunfo de sus respectivas revoluciones: Cuba y Nicaragua. Aunque el caso colombiano es sui generis, en la medida que aún sobrevive una de las dos guerras más antiguas del planeta y la única en el hemisferio occidental, que además se sumó al convergente fenómeno de los años ochenta cuando emergió el narcotráfico con sus poderosos carteles. No obstante que muchos de esos fenómenos cesaron o mutaron en su intensidad, las secuelas han continuado:

[...] Es evidente que en América Latina la violencia político-militar ha disminuido, pero se han agravado otros tipos de violencia social y el crimen organizado en redes transnacionales. Los homicidios dolosos alcanzan 25,1 por cada 100.000 habitantes, el nivel más alto del mundo y tres veces la media mundial... En las dos últimas décadas, la violencia fue la principal causa de muerte entre los latinoamericanos de entre 15 y 44 años. El coste económico de la violencia alcanza niveles muy altos. El Banco Interamericano de Desarrollo estima que éste se situaría entre los 140.000 y los 170.000 millones de dólares anuales, lo que equivale al 12\% del PIB anual regional... Buena parte de esos costes es atribuible a la contratación de seguridad privada, sólo accesible a los más ricos, lo que supone un factor añadido de desigualdad en la región. (Mesa, 2006: 210)

Pero ¿qué es lo que hace que la ciudad Latinoamericana sea tan conflictiva? Muchos factores pueden explicar estas circunstancias. La primera es la fractura social, las diferencias sociales son abismales. Las brechas entre ricos y pobres evidentes. La ciudad latinoamericana tiene rota su geografía, más que cualquier tipo de ciudad de otras regiones del mundo, en zonas de miseria, zonas de clases medias y zonas exclusivas para muy ricos. América Latina es la región más desigual del mundo, desigual no solo económicamente sino en el acceso a las instituciones, a los bienes y a los servicios. Otros factores estarían asociados a la inacción y debilidad institucional, que además en particular se suma a la ineficacia y la corrupción, que hacen que los cuerpos policiales tengan que competir con poderosas organizaciones criminales, que permanentemente amedrantan e interfieren la acción de la justicia. Otro de los problemas es el legado de los con- 
flictos armados de las últimas décadas. Al final de las guerras centroamericanas emergieron simultáneamente las llamadas "maras", grandes pandillas juveniles de tamaño y capacidad de acción nunca vistas, globalizadas en la medida en que se mueven en varios países y en los Estados Unidos, para poner un ejemplo.

En el caso colombiano, aunque el conflicto armado disminuyó en su intensidad, un imperfecto proceso de desmovilización ha hecho que en las principales ciudades se alojen trashumantes 58.005 desmovilizados de la lucha armada. Se calcula que al menos 30 mil de ellos se encuentran en la ciudad de Bogotá donde la criminalidad organizada ha crecido significativamente en los últimos dos años ${ }^{21}$.

\section{Figura 7. Desmovilizados de los grupos ilegales en Colombia 2002-2010}

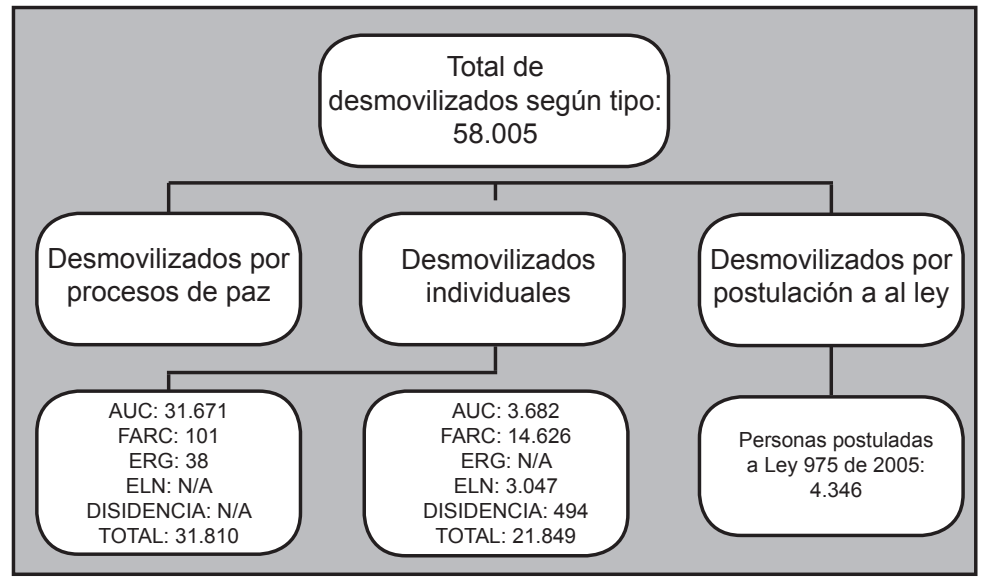

Fuente: Colombia. Oficina del Alto Comisionado para la Paz, Consejo Comunal de Gobierno 305, julio 26 de 2010.

Pero todas estas manifestaciones violentas, siendo consecuentes con el triángulo de Galtung, son la parte visible de los fenómenos. Para Colombia las cifras son muy dicientes: tiene el $49 \%$ de su población en situación de pobreza y el $14 \%$ en condiciones de indigencia. Presenta tasas de desempleo crónico de dos dígitos, como ya hemos visto, 2,5 millones de personas mayores de 15 años analfabetos, 750 mil niñas y niños entre 5 y 11 años por fuera del sistema edu-

21. Especialmente de las Autodefensas Unidas de Colombia, especie de ejército de contrainsurgencia de los narcotraficantes que negoció su desmovilización con el gobierno mediante los mecanismos de la ley de Justicia y Paz: Colombia (25, julio, 2005). Ley 975. Por la cual se dictan disposiciones para la reincorporación de miembros de grupos armados organizados al margen de la ley, que contribuyan de manera efectiva a la consecución de la paz nacional y se dictan otras disposiciones para acuerdos humanitarios 
cativo de preescolar y primaria, 1,2 millones de adolescentes entre 12 y 17 años desescolarizados, 3,9 millones de jóvenes entre 18 y 24 años aún no asisten a la educación superior o de formación para el trabajo. Un alto porcentaje de esos niños y jóvenes viven en las barriadas de las ciudades capitales. Estructuralmente estas personas están por fuera de toda posibilidad de vida digna, de inserción económica futura con algún grado de éxito y de obtener un trabajo estable. Son los desesperanzados de las grandes urbes.

\section{La ciudad, utopía y anti-utopía}

Pero la ciudad latinoamericana no se ha hundido. Observatorios de seguridad ciudadana y políticas acertadas coherentes y sostenibles han demostrado que es posible revertir situaciones que parecían imposibles si se acompañan de políticas públicas adecuadas, generación de empleo, vivienda, salud y educación, es decir, políticas sociales adecuadas. Observatorios de seguridad ciudadana y de violencia urbana se han convertido en importantes herramientas para la evaluación y seguimiento de las manifestaciones delincuenciales y violentas que organizan la información, realizan diagnósticos focalizados, georeferencian fenómenos detectan zonas y conductas señalando situaciones de riesgo, horarios, sitios, poblaciones vulnerables, entre otras, lo que permitiría procesos participativos en los que las comunidades y las autoridades concerten políticas y acciones preventivas de corto, mediano y largo plazo. Cada vez es más evidente que los gobiernos de las grandes ciudades tienen a la mano herramientas que pueden llevar a soluciones si las políticas son coherentes y sostenidas.

Medellín fue un modelo a seguir: prioridad de obras de amplio impacto social acompañado de campañas educativas y preventivas, focalizadas a los sectores más vulnerables y acompañadas de acciones integrales de organismos públicos y privados, canalizando recursos con responsabilidad social entendida como el complemento de la acción oficial, por ejemplo. Bogotá, también logró hacer en el pasado reciente esfuerzos de coherencia y anticorrupción en algunas coyunturas y administraciones que hicieron sostenibles y durables las acciones públicas durante períodos más allá de la duración de los gobiernos.

Hay soluciones pero no son fáciles ni simples. No podemos convertir a la ciudad latinoamericana en una especie de anti-utopía, utopía perversa o "distopia" en el sentido de Stuart Mill y Bentham, donde la realidad transcurre en términos opuestos a los de una sociedad ideal. Es decir en contravía del deseo. La literatura y sobre todo el cine futurista han usado a Nueva York como escenario 
hobesiano de la ciudad cárcel de todos contra todos y de las guerras del Leviatán del futuro. Los diagnósticos son claros: La ciudad no es sinónimo de degradación sin esperanza si y solo si la sociedad cambia, la ciudad también puede cambiar radicalmente de rumbo. Sabemos que no puede haber megalópolis sin políticas de largo plazo y sostenibilidad ambiental, económica y política, sin trabajo reconstructor de la diversidad cultural. Es decir sin Estado y sin ciudadanía (en el sentido mismo del origen del término: ciudadano de la ciudad Estado, ser político que decide).

Pero la ciudad, habitáculo que fue cuna de la civilización puede y de hecho, parece ser una probabilidad, la tumba del proceso civilizatorio de la humanidad. Hay que reconocer la crisis de la ciudad latinoamericana, pero en el sentido de Norbert Elías, transformar la crisis de las megalópolis en una oportunidad de participación, transformación en inclusión. Aunque no depende solamente de nosotros, menos en el contexto de la ciudad globalizada.

\section{Sobre la ciudad globalizada y posmoderna}

Uno de los fenómenos que fue creciendo con el siglo $\mathrm{XX}$ fue la ciudad, la megalópolis que le impuso a todos los asentamientos de cierto tamaño un modo de ser y ante todo manifestaciones de inseguridad y violencia que en términos generales se viven en estos espacios de tamaño inimaginable uno o dos siglos atrás. El modelo de ciudad que hoy conocemos es producto de las sociedades industriales con su necesidad de creación de grandes concentraciones de bienes, servicios y recursos y sobre todo de mano de obra abundante y barata para la gestión de las actividades principalmente fabriles y comerciales. Inicialmente a pocos importaban las condiciones de vida de estas concentraciones humanas sometidas a ritmos de trabajo totalmente inhumanos, en tanto que sus familias se hacinaban de cualquier manera en las barriadas. Muchas de ellas surgieron en los puertos donde además la figura más frecuente era la del forastero. En América Latina la situación no fue diferente, sino que fue más tardía. Mientras que en las sociedades metropolitanas europeas fueron un fenómeno que floreció con la primera revolución industrial, siglos XVIII y XIX, en los Estados Unidos fue un proceso de la segunda mitad del siglo XIX y comienzos del XX, mientras que en América Latina, Asia y parte de África ha sido el fenómeno sui generis del siglo $\mathrm{XX}$ y XXI.

Al llegar al siglo XXI una rápida mirada a los estudios hechos por Naciones Unidas y por la CEPAL nos muestra que en las tres últimas décadas, la población 
urbana de América Latina se ha incrementado un 240 por ciento, mientras que la población rural lo ha hecho sólo en un 6.1 por ciento creando un desequilibrio demográfico importante dado que la población urbana paso de ser en 1990 el $71 \%$ a ser el $77 \%$ del total poblacional en el año 2007 . Así las cosas, somos la región más urbanizada del planeta, hasta el punto de que hay países como Argentina, Chile, Uruguay y Venezuela que están urbanizándose aceleradamente a tasas del $86 \%$.

Este modelo de crecimiento desordenado y no planificado está generando en muy pocos años verdaderas megalópolis como Sao Pablo, Ciudad de México y Buenos Aires, que ya ingresaron al grupo de las 10 ciudades más grandes del planeta, modelo al que le siguen Río de Janeiro, Bogotá, y Lima. Es decir que en el 2015 la región tendrá 6 de las 10 mega-ciudades del mundo.

Esto no sería tan grave si este crecimiento de las ciudades y de la población no estuviera acompañado de un crecimiento acelerado de la pobreza. Los habitantes en situación de pobreza pasaron de 180 a 189 millones en 2009, lo que equivale a más del $34 \%$ de la población, mientras que la indigencia creció de 71 a 76 millones, es decir el $13,7 \%$ de los habitantes.

\section{¿Cuáles son las consecuencias de este crecimiento urbano?}

En 1950 teníamos 167 millones de habitantes y en 2007 pasamos a ser 572 millones. Para el 2030 se espera que las ciudades alberguen 607,7 millones cuando el grado de urbanización será de $84 \%$. Es el reflejo de un crecimiento demográfico sin crecimiento económico al mismo ritmo y con alta concentración de la riqueza en manos de nuevas clases emergentes y en polos de desarrollo desigual que generan inequidades sociales muy notorias y desequilibrios geográficos enormes.

La ciudad Bipolar: Vamos a tener zonas altamente desarrolladas al lado de zonas enormemente deprimidas en nuestras ciudades como ya lo estamos viendo, dado que la concentración poblacional no está acompañada de crecimiento del empleo, especialmente en los grupos de población menor de 25 años. Esta población joven queda sometida a la informalidad que en algunas ciudades alcanza tasa de más del $40 \%$ del mercado de trabajo.

Hábitat sin vivienda: Otro problema que genera el modelo es el déficit de vivienda digna. Ninguna ciudad ni ningún país puede tener los recursos suficientes 
para proporcionar vivienda digna a esa verdadera invasión de migrantes y de nuevas familias, lo que convierte el tener una casa o un apartamento en un verdadero privilegio para un bajo porcentaje de la población nueva, elevando la renta urbana y expandiendo el problema aún más a las ciudades dormitorio, gestando procesos de conurbación que trasladan muchos de los problemas a las pequeñas poblaciones del entorno.

Déficit y encarecimiento de los servicios: El otro problema es que no todas las nuevas zonas de poblamiento pueden tener atendidas su provisión de servicios públicos, especialmente de agua y saneamiento básico, disposición de excretas y residuos sólidos. Muchas zonas de pobreza de estas grandes ciudades están condenadas a convivir en verdaderos basureros con proliferación de problemas sanitarios. En este momento en las ciudades latinoamericanas existen 20 millones de pobladores sin acceso a servicios de agua potable y 65 millones sin servicios de saneamiento básico.

Población infantil y juvenil en incertidumbre insostenible: Este será y es actualmente uno de los problemas del crecimiento. Las grandes concentraciones urbanas con tasas de fecundidad altas, hacen que se concentre la necesidad de servicios de atención en salud, educación, recreación y desarrollo cultural para los grupos etáreos más jóvenes de la pirámide, para lo cual no hay el desarrollo, pertinencia y focalización necesaria de dichos servicios. Por ejemplo, es muy difícil planificar la localización de esta población. En los años setenta se dotó a muchos barrios y sectores de la ciudad de escuelas. En diez años los usos del suelo urbano cambiaron. Los sectores residenciales se volvieron comerciales, por ejemplo, y la población se desplazó a otras zonas y muchos de esos colegios quedaron vacíos y sus maestros cesantes. Lo mismo sucedió con jardines y servicios de salud. Los mega-colegios de hoy muy seguramente van a quedar sin uso, además porque la demanda de servicios educativos varía según los grupos de edad. Uno de los problemas más grandes del crecimiento urbano que tendrá que atender la ciudad latinoamericana está siendo el problema de su población infantil y juvenil, no solo por la capacidad y cobertura de los mismos, sino por su focalización y localización cambiante. En tanto en las poblaciones del área de influencia se están desperdiciando recursos como producto del vaciamiento de regiones enteras por efecto de las migraciones, en tanto que los recursos no son fácil y rápidamente asignables donde se necesitan.

Este ha sido el principal problema de la atención a la familia, la educación. Las demandas cambiaron y las ofertas están ligadas a muchas contingencias de las 
burocracias, los tecnócratas y los sistemas administrativos, además de la corrupción, la indolencia e inefectividad administrativa y política de los gobiernos. Mientras la respuesta administrativa y burocrática se da, los niños han crecido sin educación adecuada, los jóvenes se han hecho adultos sin educación, las madres gestantes han sido abandonadas a su suerte y muy seguramente, las personas de la tercera edad habrán fallecido esperando de los gobiernos de su ciudad alguna política que mejore su situación.

La pérdida de cause de las políticas públicas en lo social: Los defensores del modelo actual saben que es más fácil decir que sea el mercado el que deba solucionar estos problemas de la sociedad, especialmente en el campo de la prestación de los servicios y de paso liberar recursos para invertir en otras "prioridades". Y más en el campo de lo social que se volvió coto de caza de los financistas. Puede ser que el mercado sea más ágil que el Estado, pero aquel lo hace a su manera: solo atendiendo a dos únicos criterios: la ganancia y la visón de sus agentes, los mercaderes, que con frecuencia es simplemente uno: el interés por la ganancia desaforada; claro está, puede ser más ágil pero no se puede direccionar contra sus intereses, no puede invertir donde no es rentable y no actúa a cambio de nada. Su interés no es lo humano y de lo que estamos hablando es del desarrollo humano de los seres humanos. Además, el mercado no sabe de las necesidades de un niño desde el jardín hasta la universidad y como no se interesa por los desajustes ni por los "daños colaterales" que causa, ni por los costos en términos de dolor y angustia, ni le interesa el desempleo que genera, y los daños sociales que ocasiona, campea por el mundo como un depredador gigantesco.

Han pasado solamente dos décadas desde que la euforia neoliberal invadió las políticas públicas globales, que no es nada, y hoy vemos como ejemplo la catástrofe humanitaria de la salud, no solamente en Colombia sino en el mundo, para no hablar de la educación, que hoy es el nicho de mercado más apetecido por las corporaciones transnacionales y nacionales. No en vano de educación y de salud habla más el Banco Mundial que la UNESCO y la OMS juntas y sus dictámenes son letra central de los tratados de comercio. Pero quizás la consecuencia más importante del "modelo" es el tema de la pobreza.

\section{La pobreza en Bogotá}

Sin embargo la situación de Bogotá no se encuentra en el peor de los escenarios. En la última década la ciudad ha mostrado un mejoramiento de su desempeño, o al menos eso muestran sus principales indicadores, (con excepción de la coyuntura que atraviesa en el momento de escribir estos textos, cuando la corrupción 
arruinó estrepitosamente el gobierno de la ciudad y a la ciudad misma, sin que todavía se conozca la dimensión exacta del daño hecho).

En medio de dificultades administrativas, Bogotá había logrado importantes avances en estas materias. Según informes del Departamento Nacional de Planeación, DNP la proporción de población de Bogotá bajo línea de pobreza pasó de 38,9\% en 2003 a $23,8 \%$ en 2006 . De acuerdo con la misma fuente, la población bajo línea de indigencia en la ciudad también se redujo, pues pasó de $9,1 \%$ en 2003 a 3,4\% en 2006. El Índice de Condiciones de Vida, tuvo un desarrollo positivo al pasar de 87,5 en el 2003 a 88,6 en 2006. El Coeficiente de Gini, indicador de desigualdad en términos de ingresos monetarios, también muestra un avance significativo al pasar de 57,11 a 53,23 entre 2003 y 2006, indicando un paso de mayor desigualdad a menor desigualdad en Bogotá22.

\section{Figura 8. Porcentaje de personas en pobreza y miseria en Bogotá según NBI 2001-2005}

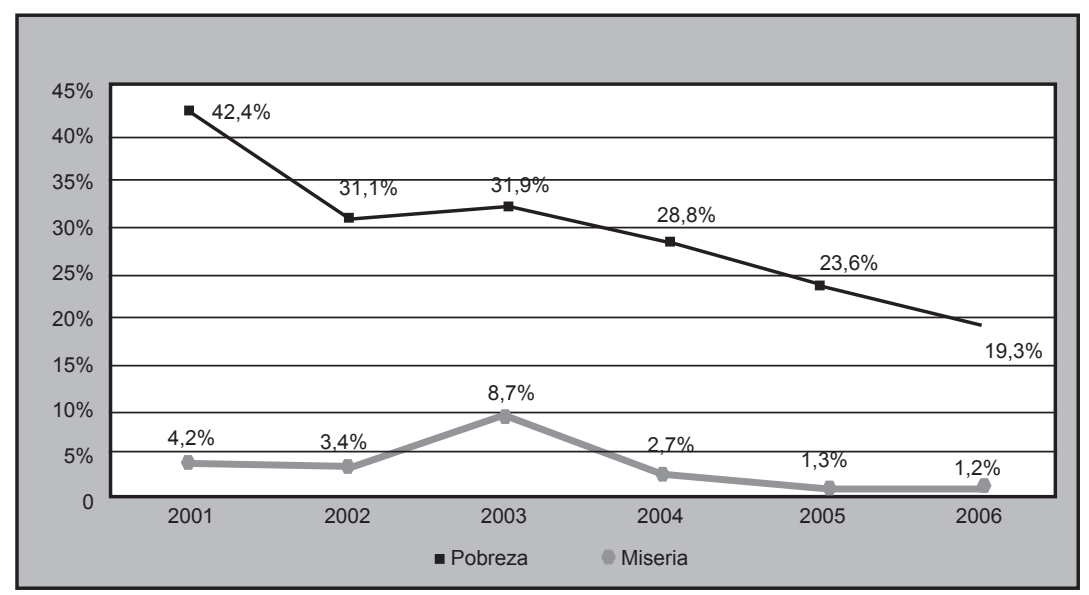

Fuente: Colombia. Departamento Nacional de Planeación (DNP). Con base en la Gran Encuesta Integrada de Hogares (GEIH) del DANE, 2006.

Un estudio realizado por "Bogotá Cómo Vamos" y el Programa Nacional de Desarrollo Humano (2005), muestra que el indicador de pobreza es de $43,4 \%$

22. Colombia es el segundo país con mayor concentración de ingresos de América Latina, apenas superado por Brasil. El coeficiente Gini aumentó en los años noventa en Colombia hasta llegar en el 99 a un nivel de 60. A partir de 2000 la tendencia ha sido decreciente. Disponible en: <http:// manuchao123.blogspot.com/2008/03/entrada-15.html> 
de la población de Bogotá, debido a la carencia de ingresos. Sin embargo, de ese porcentaje sólo se percibe o manifiesta ser pobre el $31 \%$. Las principales razones por las cuales se considera pobre están relacionadas con incapacidad de generar ingresos. El estudio detectó que este problema de pobreza se refleja en primer lugar, en problemas con la alimentación por falta de ingresos, en la medida que el $12 \%$ de los hogares manifiesta haber dejado de consumir alguna de las comidas, especialmente en población de menores de edad.

El Índice de Condiciones de vida, (indicadores de tipo multidimensional), evidenció un logro importante en materia de infraestructura física y condiciones de vida (Necesidades Básicas Insatisfechas NBI, ICV e IDH ${ }^{23}$ ) en la ciudad desde el año 2001. Bogotá cuenta con el ICV más alto del país (por 13 puntos) y los avances en los indicadores estuvieron presentes en todas las zonas de la ciudad de manera notable.

En este marco, una de las principales conclusiones es que Bogotá ha avanzado en proveer servicios públicos domiciliarios e infraestructura. Sin embargo, a pesar de este avance aún el $7,4 \%$ de la población se encuentra en pobreza estructural (cerca de 450 mil personas). Igualmente, se halló que al caracterizar la pobreza en la ciudad, el mayor porcentaje de la población asociaba la pobreza debido a los bajos ingresos, más que a las condiciones estructurales de vida, es decir que la percepción es que su pobreza es pasajera y que puede cambiar cuando se modifiquen sus ingresos, es decir, cuando obtenga un trabajo.

Se pudo establecer que la población pobre en Bogotá, aunque se encuentra en todas las zonas de la ciudad, se concentra principalmente en el Sur-Occidente

23. NBI utiliza indicadores como Vivienda inadecuada: material del piso de la vivienda en tierra o con material biológico en las paredes. Servicios básicos insuficientes: vivienda que no tiene acceso adecuado a acueducto y alcantarillado. Hacinamiento crítico: cuando viven más de tres personas por habitación y es uno de los indicadores de pobreza más usados. En Colombia existe una gran brecha entre los hogares rurales y urbanos en materia de NBI. Este indicador no permite medir el grado de pobreza, es decir, que no se puede saber qué tan pobre es un hogar con relación a otros. Índice de Condiciones de Vida (ICV): Pondera doce variables que miden la calidad de la vivienda y el grado de escolaridad de los miembros del hogar. Un valor de $100 \%$ refleja la ausencia plena de pobreza. En 2003 el ICV total nacional fue de $78 \%$, cinco puntos por encima del nivel de 1993. El Índice de Desarrollo Humano (IDH) es un indicador compuesto diseñado por el PNUD en 1990, que busca contar con una medida más amplia de bienestar, más allá del PIB. Para medir el progreso medio considera tres indicadores del desarrollo humano (que se reducen a una medida común entre 0 y 1 ): • Vida larga y saludable (medida por la esperanza de vida). Educación (medida por la tasa de alfabetización de adultos y de matriculados en enseñanza primaria, secundaria y terciaria). Nivel de vida digno (medido por el índice de PIB per cápita en dólares en términos de paridad del poder adquisitivo). El IDH de 2005 para Colombia la ubicó en el puesto 75 en comparación con 177 países del mundo analizados, bajando 5 puntos en relación con su posición en 2004. 
y Sur-Oriente: Localidades de Bosa, Tunjuelito, Ciudad Bolívar, Rafael Uribe, Antonio Nariño, Usme y San Cristóbal.

Con respecto a los factores que parecen centrales para la reducción de la pobreza, los resultados muestran que es importante resaltar que el empleo y el aumento sostenido de los ingresos de los pobres parece ser clave para avanzar en mejorar la situación. La acumulación de capital humano y el acceso a trabajo remunerado son los factores que explican las diferencias entre zonas. Si se desea reducir la inequidad en la distribución del ingreso estos dos aspectos deben ser una prioridad para la administración distrital. De las estimaciones del DANE sobre la encuesta de Calidad de Vida 2008, que corresponde a los datos más recientes, se evidencia este mejoramiento de la calidad de vida de los hogares bogotanos, un aumento en la cobertura de los servicios sociales de educación, salud y de comunicación.

Otro aspecto que llama la atención de los realizadores de este estudio es que establecen con claridad la magnitud del grupo más vulnerable, en lo que coincide en sus resultados con la encuesta del DANE: y es que el grupo que debe ser atendido prioritariamente es el de hogares con jefatura femenina.

En el 2008 , el $29,8 \%$ de los hogares del país tienen jefatura femenina, lo cual indica que este ítem creció 1,2 puntos porcentuales más que el $28,6 \%$ que arrojaba para el 2003. El escenario para los hogares de las ciudades o cabecera es de $32,9 \%$ en 2008 , frente al $31,6 \%$ en 2003 . Este grupo contiene el subgrupo de la jefatura sin cónyuge en el hogar con hijos menores de 18 años, en el 2008, aunque se reduce de $42,6 \%$ a $41,7 \%$. Estos porcentajes muestran claramente la transformación del patrón de familia. Aunque no dispusimos de cifras específicas para Bogotá es un dato que debe ser tenido en cuenta.

El gran problema de Bogotá y del país es cómo romper el círculo vicioso: los pobres lo son muy seguramente porque en su infancia y juventud no tuvieron acceso a la educación o a educación de calidad, y porque su entorno era pobre o ambas circunstancias, esto les disminuyó sus posibilidades de inserción laboral; tampoco tuvieron acceso a vivienda y salud, y los obligó a habitar entornos marginales, donde sus ingresos no podían mejorar fácilmente. Eso en lo micro. En lo macro, porque viven en una sociedad con dificultades para romper las "trampas de pobreza", donde el que nace pobre debe seguir siendo pobre y sus hijos tendrán una alta probabilidad de continuar el ciclo. Porque viven además en una sociedad con altas tasas de concentración de la riqueza, sin grandes 
preocupaciones por la suerte de los más vulnerables. Es decir, en una sociedad sin grandes preocupaciones o posibilidades de inversión en "lo social" y una sociedad poco innovadora para solucionar estos problemas secularmente.

La otra cara del análisis es que la educación no es una garantía futura para salir de la pobreza pero está demostrado que la probabilidad de seguir siendo pobres de quienes logran estudiar es menor y que la educación y el acceso al conocimiento previene muchos riesgos sociales.

Por eso, cada vez que un niño es desescolarizado está siendo arrojado al abismo de la total incertidumbre, y doblemente si proviene de una familia pobre; el problema se complejiza al mantener mediocres tasas de cobertura de educación superior y de formación para el trabajo como lo ha hecho Colombia ${ }^{24}$.

\section{El desplazamiento en Bogotá}

Otro problema importante a tener en cuenta en este análisis de contexto es el desplazamiento forzado. María del Carmen Pinilla, sustenta que durante los años de la crisis humanitaria que vive Colombia Bogotá se ha convertido en la primera ciudad receptora de población en situación de desplazamiento del país (Pinilla, 2009).

Según cifras de la Consultoría para los Derechos Humanos y el Desplazamiento -CODHES - del año 2008, Bogotá es la ciudad de mayor recepción de la población desplazada. Entre 1985 y 2006, se calcula que a Bogotá y Soacha han llegado alrededor de 666.590 desplazados, procedentes de 29 de los 33 departamentos del país. Según estos datos del estudio Gota a gota, el desplazamiento en Bogotá y Soacha, estas dos ciudades estarían albergando el $16 \%$ de la población desplazada de todo el país. Un promedio de 93 personas desplazadas diariamente estarían llegando al Distrito Capital y 11 personas a Soacha (Pinilla, 2009: 17).

24. Según datos del Ministerio de Educación, en la última década la tasa de cobertura bruta de educación superior pasó de $24.5 \%$ en 2002 a $37 \%$ en 2010. "Las posibilidades de desarrollo y bienestar del país dependen de que esta tendencia se mantenga dado el fuerte impacto de la educación en el bienestar de la población dada su alta rentabilidad individual y social". Sin embargo, al parecer el aumento de la cobertura se debe más que a un aumento significativo real, como aparece, a la inclusión de SENA y la educación para el trabajo como formación de educación superior, lo que no quiere decir que no haya habido un esfuerzo de inversión, no obstante que es absolutamente insuficiente. 
El Sistema de Información de Población Desplazada de la Agencia Presidencial para la Cooperación Internacional y la Acción Social afirma que hasta el 30 de septiembre de 2008, se han desplazado al interior de Colombia 610.342 hogares que representan 2.703.550 personas. En Bogotá a la misma fecha se encuentran 59.325 hogares de población desplazada que corresponden a 226.372 personas. A su vez, el $51.1 \%$ de la población desplazada de Bogotá corresponde a mujeres y el $48.8 \%$ a hombres. Durante el tercer trimestre de 2008, aproximadamente 520 nuevas familias llegaron a Bogotá, de las cuales el $58 \%$ fueron mujeres declarantes y el $42 \%$ fueron hombres. El $64 \%$ de las familias atendidas en la UAO residen en la localidad de Suba, seguida por la localidad de Engativá, en donde se registran el $20 \%$ de las familias que acuden a la UAO. Adicionalmente, en las localidades de Usaquén (359 familias) y Barrios Unidos (81 familias) (Pinilla, 2009).

[...] Al llegar a Bogotá, las familias desplazadas se ubican en los sectores más pobres de las localidades se Suba, Ciudad Bolívar, Bosa y Usme entre otros sectores, caracterizados por el alto riesgo geográfico y social, por el predominio de estratos 1 y 2 y por condiciones de vivienda críticas. A las difíciles condiciones de base se le suman nuevos gastos de difícil asunción. El $71 \%$ de la población desplazada en Bogotá vive en arriendo, el $24 \%$ comparte viviendas y el $45 \%$ viven en hacinamiento crítico, como inquilinatos. El $47.3 \%$ no tiene acceso a energía, acueducto, alcantarillado y recolección de basuras, el $26 \%$ vive en casas construidas con materiales inapropiados (Pinilla, 2009, 23).

Como podemos ver, esta rápida radiografía a las situaciones de desplazamiento y pobreza de la ciudad capital nos dan un contexto de la textura de lo social en una metrópoli de este tamaño en la que las urgencias sociales son lo predominante.

\section{Las políticas de vivienda y el surgimiento del barrio obrero}

La historia de los barrios de la ciudad obedece en el siglo XX principalmente a las políticas de la vivienda obrera, también conocida como vivienda económica o social, posteriormente denominada de interés social. Las políticas inspiradas en visiones de la acción social católica e higienistas ${ }^{25}$ (Martínez et al, 2012),

25. La crisis que produjo la pandemia de gripa en 1918 fue el principal motivo para que las políticas públicas incluyeran el tema de la vivienda obrera, lo cual reforzó y llenó de argumentos a la ideología higienista, en boga por esos tiempos. El decir era que las "infecciones" salieron de las covachas miserables del paseo Bolívar en el oriente de la ciudad. Sobre la pandemia: (Martínez, et al, 2012). Sobre la vivienda en Bogotá: (Díaz, 2006), (Colón, 2007). 
predominaron en la primera institución denominada Habitaciones para Obreros (1919 y 1932) ${ }^{26}$, que posteriormente fue reemplazada por el Instituto de Acción Social (1932 -1942), ente que combinaba las políticas del Estado de bienestar que emergió en los años 30 para el afrontamiento de la gran crisis y la fuerte ideología del higienismo que continuaba siendo hegemónica ${ }^{27}$. La idea de una política estatal de vivienda popular se institucionaliza en $1942^{28}$ y perdura con algunas modificaciones y concesiones crecientes al capital financiero y los urbanizadores privados hasta el surgimiento del sistema UPAC, cuando se consolida el modelo privado hasta 1991. Las políticas sociales del Estado social de derecho consagrado en la Constitución de 1991 instauran una etapa de subsidio a la demanda que aún se mantiene. La ciudad de Bogotá ha tenido desde 1927 su propia política de vivienda social: El instituto de Acción Social, (1927), reemplazado por la Caja de Vivienda Popular, (1942) y METROVIVIENDA, (1998).

¿Qué había sucedido? Las primeras intervenciones se hicieron con marcado matiz religioso dentro de la concepción de la caridad y el higienismo a raíz de la pandemia, la doctrina social católica había sido adoptada por la República Conservadora, y dentro de estas dos concepciones se creó la Junta de Habitaciones para Obreros (1919 y 1932), reemplazada luego por la el Instituto de Acción Social (1932 y 1942) que cristaliza una política de solidaridad y de Estado de Bienestar. En 1924 ya se había construido el barrio Buenos Aires y se estaba por iniciar la construcción del barrio Primero de Mayo y el barrio y Acevedo Tejada. En tanto que la cervecera Bavaria había construido para sus obreros el Bario la Perseverancia.

La Junta de Habitaciones para Obreros compró lotes en la zona del Paseo Bolívar, iniciando la construcción de viviendas urbano populares en 1922, decíamos que el Barrio Buenos Aires inaugurado en 1926, luego el Acevedo Tejada y el

26. Previamente se había expedido la Ley 46 de 1918, que en su artículo 7 reza: "Artículo 7 . Es obligación de los Municipios que tengan más de quince mil (15.000) habitantes destinar el dos por ciento (2 por 100) del producto de sus impuestos, contribuciones y rentas, a la construcción de viviendas higiénicas para la clase proletaria. Dichas viviendas tendrán que llenar las condiciones determinadas por la Dirección General de Higiene; por habitarlas se cobrará solamente un arrendamiento equivalente al seis por ciento ( 6 por 100) anual del valor de su costo, más un cuatro por ciento (4 por 100) sobre el mismo valor, destinado a cubrir éste; todo conforme a los reglamentos ejecutivos de esta Ley, y a los que, sin contrariar los ejecutivos, dicten los respectivos Concejos Municipales". Mediante Ley 68 de 1924 se crea el Banco de Crédito Agrario y se reglamentan los créditos hipotecarios.

27. En 1931, como herramienta financiera, se crea la Caja de Crédito Agrario, complementado con el Banco Central Hipotecario en 1932.

28. En 1939 se inicia una era de políticas de vivienda con la creación del Instituto de Crédito Territorial, ICT, con el que va a consolidar desde 1942 la política liberal sobre el Bienestar y la solidaridad. 
Carlos E. Restrepo, supuestamente para los desalojados del Paseo Bolívar. Pero en la práctica los desalojados terminaron en los inquilinatos de las Cruces, el barrio Egipto, el sector del Viejo Santa Bárbara. Rápidamente la ciudad creció por todos sus costados, emergieron los grandes y medianos urbanizadores, que creaban parcelaciones, donde se construirían las urbanizaciones que se volvería luego barrios: Antonio Ricaurte, Uribe Uribe, y Alfonso López, al occidente de Chapinero. Entre tanto las comunidades religiosas como los Jesuitas impulsaron San Francisco Javier y el complejo de Villa Javier al sur de la ciudad.

El sector del Paseo Bolívar, comprendido entre el Parque de la Independencia y la Plaza del barrio Egipto aglutinaba Barrios como San Ignacio de Loyola 1, San Ignacio de Loyola 2, San Luis, San Martín, San Miguel, La Peña, Sans Façon. Entre tanto, los barrios populares como Las cruces, se fueron deteriorando socialmente por la densificación y la fragmentación de las casonas a causa de las herencias y emergieron en pleno centro de la ciudad nuevos asentamientos informales, casitas pequeñas, de paja, y los predominantes inquilinatos. Se avanzaba socialmente dado que la mayor parte de las viviendas obreras existentes en ellos contaban con agua potable, baños, alcantarillado, y algunos con servicio de recolección y disposición de basuras, pero la expansión rápida de la ciudad hizo que en la periferia estos servicios no pudieran ser ampliados con la misma rapidez.

Posteriormente se creó la Caja de Vivienda Militar (1947) y el Fondo Nacional de Ahorro (1968) para canalizar las cesantías de los funcionarios públicos. Sin embargo las clientelas urbanas crecieron y las clases medias presionaron a los políticos. Muchos de los barrios obreros construidos fueron entregados a las clases medias, especialmente a la capa de empleados públicos de bajo y medio rango, y las crecientes necesidades de vivienda popular y obrera se fueron aplazando o fueron atendidas con déficit

La zona sur de la ciudad empezó a crecer a medida que la violencia de los años cuarenta se expandía por las zonas rurales; fue en el sur, hacia las haciendas trigueras entre Bogotá, Usme y Bosa. Surgieron rápidamente los barrios Luna Park, San Bernardo, Las Mercedes, Olaya Herrera, Bravo Páez, Libertador, Santander. En el norte Calderón Tejada, y Llano de la Mosca, Las Margaritas, Barrios Unidos de Chapinero. En el centro, al sur del tradicional barrio Egipto y hacia los cerros, aparecen barrios informales como el Girardot, La Peña. El sur de la ciudad se va transformando en el sector urbano-popular por excelencia, ya no conformado por urbanizaciones formales sino por casa-lotes de auto cons- 
trucción progresiva. Mientras las "urbanizaciones" se veían bonitas, uniformes y terminadas, fueron apareciendo barrios en permanente "obra negra".

En los años cincuenta y sesenta se siente el impacto de la urbanización realizada por instituciones públicas como el Instituto de Crédito Territorial, ICT, la Caja de Vivienda Popular, el Banco Central Hipotecario, y los urbanizadores privados. Barrios como el Quiroga (Nueve etapas, con diferentes tipos de vivienda popular y de clases medias), Ciudad Kennedy, Muzú, El Sosiego y el Centro Urbano Antonio Nariño. El barrio Los Alcázares en Bogotá es, cronológicamente la urbanización del Instituto de Crédito Territorial (ICT), iniciada en 1948 y ubicada en el noroccidente de la ciudad, tema que puede ampliarse en Bogotá siglo XX, urbanismo, arquitectura y vida urbana. (Saldarriaga, 2000) 


\section{El barrio urbano-popular}

El barrio urbano popular es una intersección reciente entre el campo y la ciudad. Es un híbrido de muchas formas de expresión de esta intersección cultural. Sus elementos institucionales fundamentales son la escuela, la parroquia, la capilla, y las organizaciones comunitarias tales como la Junta de Acción Comunal, la Defensa Civil, entre otras. El parque, el salón comunal (a veces la misma capilla) y la calle son los principales espacios de sociabilidad y de construcción de comunidad barrial. Pero dicha concreción espacial urbana tiene una historia (García Sánchez, 2008,117).

La urbanización de los últimos cincuenta años en Bogotá es muy similar en su formación. Las clases medias y altas a comienzos de siglo habitaban barrios ya formados, o los que se construían por urbanizadores formales lo tenían todo. Así, el barrio ya estaba inventado por los urbanistas y arquitectos. El caso del barrio "urbano-popular" es distinto: como lo hemos visto, allí el barrio es literalmente inventado, construido con el esfuerzo individual y colectivo de la comunidad y de formación reciente, la mayoría desde la mitad del siglo XX. Independientemente del tipo de construcción, sus principales calles parecen calles de pueblo, muchos vecinos se conocen y se tratan y la mayoría se conocen de "vista". Esa estabilidad permitía que la mayoría de sus habitantes supiera más o menos a que familia se pertenecía y el lugar de residencia, destacando la supremacía de las relaciones cara a cara ${ }^{29}$.

Bogotá fue una ciudad relativamente pequeña hasta la segunda mitad del siglo XX. El nueve de abril de 1948 había abierto otro capítulo transformador no solamente del centro sino de la textura de toda la ciudad. Las migraciones masivas eran un problema diario y la respuesta estatal no daba abasto. La frontera urbana se expandió en todas los puntos cardinales.

Entre 1951 y 1964 el déficit de vivienda se cuadruplicó y la ciudad se llenó de barrios de invasión, la mayoría espontánea y uno que otro promovidos por líderes

29. Una versión más amplia del tema puede consultarse en: García Sánchez, Bárbara. Los núcleos de educación familiar: Investigación participativa para prevenir violencias difusas en escuela, familia y barrio. Tesis de maestría. Universidad Nacional de Colombia. Bogotá, 2003, y en: García Sánchez, B. Y. Familia, Escuela y Barrio: Un contexto para la comprensión de la violencia escolar. En: Revista Colombiana de Educación. 2009, 55,108-124. 
u organizaciones de izquierda, como el Partido Comunista y el Frente Unido del cura Camilo Torres y el grupo "Golconda", entre las más destacadas, el Barrio Policarpa Salavarrieta, a pocas cuadras de la plaza de Bolívar, en pleno centro de la ciudad, el Barrio las Lomas, Colinas, Nuevo Chile, Salvador Allende, Atahualpa, además de muchos barrios informales, especialmente en el extremo sur.

La respuesta estatal fue la de los llamados lotes con servicios. Los barrios experimentales fueron la Manuelita (1972) y Guacamayas (1974) y luego se expandió por toda la ciudad especialmente en Ciudad Bolívar, los más notables son Arborizadora Alta y Sierra Morena (1983):

[...] Consistía básicamente en la apertura de tierras urbanizadas, y su dotación con agua potable, alcantarillado, vías y drenaje, electricidad, y en algunos casos, vivienda, para ser entregadas a familias económicamente pobres, modalidad que tuvo gran proliferación en la década del setenta, época en la que el Banco Mundial dedicó grandes recursos a esta modalidad. (Carvajalino: 154)

Según refiere Laquian (Laquian, 2007), mencionado por Hernando Carvajalino la situación se desarrolló como:

[...] Una salida intermedia a la insuficiencia de las respuestas del Estado, frente a la dimensión del problema, entre los grandes conjuntos habitacionales de viviendas modernas, realizadas por grandes empresas constructoras o por el mismo Estado, entregadas llave-en-mano, y la solución informal de los pobladores...

Estas últimas alternativas tuvieron el inconveniente que hicieron que proliferaran los barrios urbano-populares de viviendas por autoconstrucción, con conexiones "ilegales" a servicios públicos muchas veces, y una gran disparidad de tipos de vivienda, desde las que se quedaron permanentemente como casa-lote, hasta los predios tugurizados verticalmente en construcciones de hasta cinco o seis pisos, sin estándares técnicos.

[...] Recorridos recientes por estos dos barrios, muestran un nivel de consolidación bastante alto, en el que se evidencia el esfuerzo individual y colectivo que durante décadas han venido sosteniendo los pobladores, de manera aislada de las instituciones que inicialmente los promovieron. Perfiles urbanos múltiples y heterogéneos, unidades de vivienda con diversos usos más allá del habitar propiamente dicho establecidos por parte de sus propietarios, constituyen un lugar común en estos escenarios urbanos (muy semejante al de un barrio popular de origen informal), en los que en su interior, si bien se atendió en su momento, un problema de déficit cuantitativo, a la fecha, se evidencian problemas de calidad en sus estructuras, vulnerables frente a un posible riesgo sísmico (Carvajalino: 156). 
En estas últimas modalidades de urbanización el Estado dejó en manos de los sectores más pobres de la población la solución de dos graves problemas urbanísticos: la construcción de la vivienda propiamente dicha, y el amueblamiento y acondicionamiento del barrio y su entorno, vías de acceso, conexión a servicios, acceso a salud, educación, transporte, entre otros. El primero dejando al garete a la familia a su suerte haciendo un esfuerzo continuado por años y el segundo entregado prácticamente a las Juntas de Acción Comunal, un invento de la época de la Sociología Desarrollista de los años 60 de Orlando Fals, Camilo Torres, María Cristina Salazar, entre otros en la Universidad Nacional, que fue acogido por el Ministerio de Gobierno y que es uno de los primeros productos de la IAP latinoamericana, según se analizó en Las ciencias sociales y la invención del tercer mundo: a propósito de la obra académica de Orlando Fals Borda. (Guerrero \& García, 2009: 47)

Posteriormente, en 1967 se adoptó la política de crear juntas de defensa civil en cada barrio, integradas con voluntarios bajo un férreo manejo del Ministerio de Defensa y dependiendo de la Presidencia de la República ${ }^{30}$.

Estas políticas abrieron la puerta desde los años 60-70 a cuatro formas de urbanización predominantes: 1) Urbanización formal estatal; 2) Urbanización formal privada; 3) Urbanización informal, ilegal o pirata; 4) Urbanización por invasión espontánea u organizada. Las políticas especialmente de organismos multilaterales, hicieron que desde la década del 60 fuera mínima la actividad estatal de grandes barrios acabados y entregados en condiciones óptimas para su habitación, dada la demanda creciente. Las clases medias alimentaron la segunda modalidad en la que especialmente a partir de 1972, empresas urbanizadoras y capital financiero se asociaron para el negocio de la urbanización para sectores con ingresos, habilitación para el crédito y capacidad de pago a largo plazo. La otra forma que proliferó pero que porcentualmente no se considera como la más incidente fue la modalidad 4, por invasión espontánea u organizada. En 1961 aparece la Central Nacional Provivienda - Cenaprov que impulsó las modalidades 3 y $4^{31}$. Desde entonces el gran negocio privado no solamente era la vivienda formal, en manos de las entidades financieras, sino que muchos negociantes de

30. Colombia (6, abril, 1967). Decreto 606. Sobre la creación de la Dirección Nacional de la Defensa Civil, bajo dependencia y orientación de la Presidencia de la República, en el marco de las políticas de la "guerra Fría".

31. Decimos que promovió estas modalidades en la medida en que unas veces actuaba como urbanizadora y otras como defensora de los ocupantes de hecho de los predios. [Consultado 8 enero 2011]. Disponible en: <www.dmsjuridica.com/> 
finca raíz y propietarios de terrenos suburbanos hicieron grandes ganancias "loteando" o urbanizando antiguas haciendas o predios en la periferia de la ciudad. Todas las localidades, tal vez con excepción de las zonas del centro consolidado de la ciudad, albergaron de alguna manera estas modalidades de urbanización.

Surgieron de de estas modalidades importantes formas de consolidación del clientelismo. Las juntas de acción comunal establecieron importantes intercambios de favores con las fuerzas y personajes representados en el Consejo Distrital y en general en los organismos de los municipios y departamentos, para obtener aportes para la "formalización" de los barrios y construcción de redes de servicios públicos, entre otros ${ }^{32}$.

Además de los problemas propiamente barriales, estas modalidades de formación de los barrios populares traían y traen muchos problemas de habitabilidad y de calidad tanto del barrio como de las viviendas. Estas aparentemente fáciles soluciones al grave problema del déficit cuantitativo de viviendas trajeron muchos problemas a la ciudad.

La vivienda urbano-popular progresiva, en muchas ocasiones comienza siendo una casa-lote, destinada para a una construcción de una planta, pero casi nunca es terminada siendo una unidad de vivienda unifamiliar propiamente dicha. Casi siempre se trata de familias numerosas, de familias extensas, (que cohabitan con familiares de padre y madre, y que cuando uno de los hijos forma su propia familia, con mucha frecuencia se acomoda en la misma vivienda).

Usualmente se construye más que una vivienda, una unidad multifuncional, con local comercial para renta, habitaciones para inquilinos, allegados o familiares o alguna pequeña industria. Muchas viviendas terminan teniendo usos para los cuales no fueron diseñadas, todo esto con la lógica de mejorar los ingresos. La suma de estos aspectos termina "tugurizando" verticalmente las viviendas más antiguas y hacinando y deteriorando la calidad de vida de las personas que las habitan. Inclusive, estas características las comparten viviendas unifamiliares de las primeras épocas de la vivienda popular.

32. El caso del personaje Rafael Forero Fetecua, fallecido en 1994, que ascendió económica y políticamente desde las escalas más bajas de la pirámide, imputado por urbanización ilegal, lavado de activos, auto préstamos, tráfico de influencias y en muchos procesos penales que muchas veces no prosperaron y que no obstante creó su propio partido político y llegó a ser senador de la República, es paradigmático y demuestra los poderosos intereses que mueven la actividad urbanizadora formal e informal en Bogotá, ver, http://www.semana.com/sube/rafaelforero-fetecua/45973-3.aspx. 
En muchos de estos barrios construidos principalmente por la Caja de Vivienda Popular o el ICT, e incluso en urbanizaciones privadas de clase media, especialmente en el caso de las casas unifamiliares, es difícil encontrar construcciones originales, dado que muchas veces los jardines y patios han sido construidos y el número original de pisos ha sido duplicado o triplicado. De otra parte, Diversas zonas residenciales han pasado a ser zonas comerciales. Todos los barrios, sin excepción, han desarrollado zonas o calles comerciales que han impactado las condiciones de las viviendas.

Este tipo de vivienda acrecienta el riesgo de conflictos intra e inter familiares y delitos sexuales, entre otros. Pero uno de los más altos riesgos es el de vulnerabilidad antisísmica, dado que sus deficiencias estructurales en muchos casos son evidentes.

\section{El barrio como espacio de socialización}

Familia e institución escolar necesitan visibilizar y reconocer las dinámicas sociales que los niños y jóvenes establecen con sus pares dentro y fuera de los lugares de residencia y de las instituciones educativas ubicadas en los espacios geográficos que habitan.

En la medida en que los diferentes actores padres, maestros, jóvenes, comprendan que la relaciones sociales entabladas producen eco en los otros, en esa medida se asumirá que las relaciones de violencia expresadas en la familia, la escuela o el barrio se expanden y retroalimentan, "contaminando" los espacios y prolongando el círculo viciosos de la repetición. Por ello, ningún escenario social debe ser indiferente ante el tipo de relaciones que sus miembros expresan entre sí y con los otros.

Usualmente la escuela se asume como la única formadora de niños, niñas y jóvenes y deja de lado la formación social que se da en la familia y en el barrio. El tiempo de la calle, para los padres y los maestros es tiempo perdido. Sin embargo hoy, desde la pedagogía social, hay otras visiones como la de Rogelio Marcial expuesta en "Entre el aula y la esquina":

[...] Tal vez para muchos de ellos sea de incalculable valor la educación informal que reciben en sus barrios, en los encuentros nocturnos en la esquina de reunión. La banda, la clica, el barrio, propician la solidaridad entre jóvenes y colabora en la socialización de muchos de ellos. Inclusive 
en algunos casos el grupo juvenil logra sustituir a la familia, la escuela o la parroquia en el desarrollo del joven. Sin embargo, la escuela nunca dejará de representar la posibilidad, tal vez cada vez más lejana, de acceder a una preparación formal que ayude en la calificación individual de muchos de ellos para ciertas labores o actividades. Si estos jóvenes lograran combinar la educación formal de la escuela con la educación informal de la esquina, estarían en mejores condiciones de enfrentar su realidad. No vemos el porqué de abandonar o prescindir de una de las dos fuentes de formación y socialización (Marcial, 2004).

El barrio además es escenario de muchas solidaridades e intercambios de apoyo social. Las familias barriales urbano-populares obtienen muchos beneficios de estos intercambios y apoyos ordinarios y extraordinarios. Sobre todo las madres de familia saben que muchas veces tendrán que contar con su vecina y que esto es recíproco. Y no pocas veces la familia extensa está situada en el mismo vecindario. Pero el vecindario es fuente de pequeños y grandes conflictos que complejizan sus redes sociales. Aceptando la afirmación de Michel De Certeau de que:

[...] El barrio puede considerarse como la privatización progresiva del espacio público. Es un dispositivo práctico cuya función es asegurar una solución de continuidad entre lo más íntimo (el espacio privado de la vivienda) y el más desconocido (el conjunto de la ciudad o hasta por extensión del mundo) (De Certeau, 1999: 10).

Todos los habitantes del barrio se apropian de sus espacios de acuerdo a su edad, género, ocupación y necesidades. Los artesanos, los mecánicos, los comerciantes, los habitantes en situación de calle entre otros, desarrollan actividades económicas en el barrio, le dan un uso y tienen intereses distintos. Los niños y los jóvenes lo usan especialmente como espacio recreativo. Otros simplemente como camino de acceso a su morada y como sitio de aprovisionamiento en tiendas, almacenes y supermercados.

Grupos de adultos tienen allí sus sitios de recreación, la tienda como sitio de encuentro y consumos sociales (licores), el billar y los juegos de salón, la cancha de tejo $^{33}$. Mientras que las mujeres amas de casa tienen menos espacios sociales,

33. El tejo o "turmequé" es un deporte autóctono de origen precolombino que se jugaba en la actual región del altiplano cundiboyacense, consistente en el lanzamiento desde cierta distancia de un disco o tejo, primero de piedra, luego de acero, sobre un cilindro o "bocín" enterrado, actualmente también de acero, sobre el cual se colocan pequeños sacos de pólvora que en contacto con el tejo estallan. Su práctica la hacían antes acompañada de bebida de chicha y hoy se hace acompañado de cerveza; era una diversión exclusiva de los varones, mujeres y niños eran invitados como espectadores 
se encuentran en la tienda, la carnicería o el supermercado, en conversaciones muchas veces rápidas, ya que se las ve con mucha frecuencia varias veces en el día circular con afán.

Esta diversidad de usos y apropiaciones del espacio hacen que muchos de los conflictos de la vida cotidiana se den por las formas de apropiación o usos de los espacios barriales. La mayoría de los conflictos se dan con (o a partir de) niños y jóvenes, independientemente del género, porque son los que más tiempo usan los espacios públicos y los que más interactúan en los espacios privados de los otros. No en vano Michel De Certeau afirma que: "La práctica del barrio es desde la infancia una técnica del reconocimiento del espacio en calidad de espacio social (De Certeau, 1999: 11).

A medida que el niño o niña crecen van "colonizando" nuevos espacios, primero los espacios barriales y luego otros espacios urbanos. Cuando se ingresa a la adolescencia se emprende la autonomía de vuelo respecto al nido aumentando su tiempo y distancia fuera del hogar. Cuando se es joven ya se ha apropiado de los espacios. Los adolescentes y los jóvenes construyen un lugar protagónico en el barrio. La competencia por el dominio territorial es creciente. Primero son los dos extremos de un camino de la vivienda a la escuela. Luego todo el territorio del barrio y luego de la ciudad ya que esta aparece antes sus ojos como "la principal oferta iniciática al alcance del niño que quiere salir de casa. No tiene bastante (no es posible tener bastante) con la escuela" (Dammert, 2004).

Entonces la ciudad aparece ante los ojos de los niños y los jóvenes como un territorio por conquistar, en la libertad del afuera de la escuela y de la casa:

[...] La ciudad, con todos sus espacios internos, guarda para el adolescente cierto grado de misterio y prohibición; los cuales, según G. Bataille, permiten que sean posibles la aventura, la iniciación, la educación. Por ello, los procesos de socialización exigen, en nuestras urbes modernas, que los niños y jóvenes fortalezcan su desarrollo mediante la educación formal recibida en las aulas escolares, como también con la educación informal de las vivencias cotidianas. No es de extrañarse que para muchos jóvenes sea atractivo recorrer los barrios y construir espacios propios, lo que colaborará en su socialización cuando las calles del barrio presentan una vida propia y diversificada (Marcial, 1995).

Los conflictos de la escuela siempre se darán espacialmente adentro y en sus alrededores. $Y$ alrededor de la vivienda los conflictos intra e inter familiares. $Y$ 
los conflictos que usualmente se desarrollaban al interior de la escuela y la familia, cada vez con más frecuencia invaden los espacios del barrio. En tiempos recientes o tal vez desde siempre, pero hasta ahora lo ha visualizado la sociedad como problema, el espacio barrial es conflictivo. Y muchos de esos conflictos ya no simplemente asoman por sus ventanas: son parte del teatro de lo cotidiano, porque cada vez menos, como dice el adagio, "la ropa sucia se lava en casa".

\section{El barrio y la violencia urbana}

Así como la metrópoli es un fenómeno macro social, el barrio es su correspondiente fenómeno microsocial. La ciudad de la cual hablamos en el caso de los jóvenes no es la de los grandes centros de negocios ni la de las grandes zonas comerciales. La realidad social que nos interesa para el caso de las violencias escolares es la vida de la barriada donde transcurre la mayoría del tiempo de los usuarios de las escuelas públicas, hoy denominadas tecnocráticamente como Instituciones educativas, "IE". En las ciudades tradicionales y antes del las metrópolis los barrios tenían sus propias escuelas a escala de sus necesidades. A medida que la ciudad se desarrolló obviamente el tamaño de aquellas creció y hoy se habla de "mega-colegios", instituciones de 3.000 a 5.000 estudiantes, aplicando economías de escala a la población infantojuvenil. En casi todas estas instituciones se hacen desplazamientos de población estudiantil desde otras zonas de la ciudad o desde otros barrios para cumplir con los cupos asignados. ¿Los planificadores, habrán pensado en los efectos de lo que significan estas concentraciones de población en edad escolar para un pequeño vecindario? Además, niños de corta edad deben hacer recorridos a veces de largas horas de ida y regreso por la ciudad, disminuyendo su tiempo libre y su tiempo de estudio.

Uno de los hallazgos de nuestro estudio muestra como en todas las localidades estudiadas - pero para hacer referencia a uno en particular, Fontibón, una pequeña población de origen precolombino que se anexó a la metrópoli y que aún conserva muchos rasgos pueblerinos ${ }^{34}$ —, la instauración de estas mega estructuras educativas convierte automáticamente al barrio que lo aloja en escenario de nuevos conflictos. Es esta localidad estudiada en donde concentraron varias instituciones de gran tamaño, se detectaron diversos problemas alrededor de las mismos: ventas ambulantes de drogas, atracos de los jóvenes a los ni-

34. La metrópoli bogotana ha "conurbado" a varios municipios de origen precolombino que se transformaron en parte de la ciudad, como en el caso de Fontibón: Usme, Usaquén, Suba, Bosa, Engativá. Están muy cerca de ser anexados Soacha, Chía, Cota, entre otros. 
ños, enfrentamientos entre combos, pandillas y barras, "chiquitecas"35, "bares de segundo piso", pero lo más destacado fue la rivalidad de los diferentes grupos estudiantiles por el control territorial de su entorno, impidiendo que los de otros planteles transitaran por determinadas calles, llegando a cazarse trifulcas masivas entre dos o más planteles, con heridos de gravedad.

Las grandes concentraciones educativas ayudaron a transformar el paisaje de los barrios. Usualmente el habitante del barrio se sentía dueño y confiado en su territorio. Con las migraciones, la llegada y tránsito de personas desconocidas por este territorio que siempre fue seguro, las expresiones, primero de inseguridad, y luego de violencia van invadiendo los espacios.

La mayoría de los barrios populares fueron transformándose. Es común que en casi todos ellos se vaya formando un sector comercial o una calle que concentra un mayor número de negocios. Otros incluso llegan a concentrar pequeñas empresas comerciales, industriales, talleres automotrices, de bicicletas, entre otros. Lo que va atrayendo paulatinamente otro tipo de población muchas veces extraña a los habitantes originarios. Además, la mayoría de los barrios han sido impactados por obras de infraestructura urbana que también alteran su tranquilidad.

El ambiente de pobreza y desempleo crónico, la informalidad y el ausentismo escolar, van haciendo que los barrios paulatinamente vayan albergando poblaciones que van invadiendo las calles de manera permanente, especialmente ventas ambulantes y la presencia de jóvenes que poco a poco van entablando usos del espacio que pueden dar origen a conflictos con otros sectores de la comunidad barrial hasta conformar situaciones extremas que conducen a la formación de escenarios violentos, en la antiguamente idílica comunidad. Muchos de estos fenómenos emergen especialmente por la población adolescente y juvenil.

\section{Infancia juventud y escuela: entre la informalidad y la ilegalidad}

Pero de todo este panorama, el que mayormente altera el clima barrial es el de la informalidad que crea los tránsitos hacia las ilegalidades. Con altísima

35. Nombre que se le da a sitios clandestinos de baile para menores donde usualmente se consume alcohol y en algunas ocasiones drogas. 
frecuencia, la población latinoamericana tiene que sobrevivir del denominado "rebusque", nomadismo laboral informal y de desempleo disfrazado, que impide que las familias tengan un proyecto de vida estable y donde los jóvenes llevan la peor parte. Estas circunstancias han hecho que los niños de los sectores más pobres acompañen a los padres y hermanos en actividades callejeras donde se dan aprendizajes indeseables que hacen que fácilmente se pase de la informalidad a la ilegalidad. Estos aprendizajes fácilmente se transmiten en la escuela y se reproducen con o sin el conocimiento o la anuencia de la familia.

En las escuelas y familias estudiadas, encontramos que los sectores más vulnerables son los niños y las niñas cuyos padres trabajan en la calle en la informalidad, o los que habitan la calle cuando ambos padres trabajan todo el día o usualmente integrantes de familias monoparentales, quienes por lo general habitan la calle sin mayor acompañamiento de familiares o adultos. En frecuentes ocasiones el padre o la madre o ambos se encuentran en situación de adicciones a las drogas o el alcohol, lo cual agrava la situación de pobreza y marginalidad. Se han encontrado casos extremos en que además, los familiares desarrollan actividades ilegales como el hurto, el micro-tráfico $u$ otras conductas en conflicto con la ley que son enseñadas a los niños o jóvenes creando clima de riesgo social permanente al socializar dichas experiencias y conductas en la escuela.

Pero es indudable que el pequeño hurto oportunista es el problema por el que se inicia el aprendizaje de la ilegalidad y al que habría que ponerle toda la atención necesaria para prevenir los caminos de construcción de la transgresión, primero y del delito posteriormente, luego de la repetición impune. Es un camino gradual que se desarrolla gracias a la tolerancia: del hurto oportunista, esporádico y casual, se pasa al hurto frecuente e intencionado y fácilmente se hace carrera al hurto como profesión delincuencial, siendo uno de los problemas más persistentes en las escuelas de los barrios urbanos populares.

Por ejemplo, en una de las instituciones estudiadas encontramos la conexión de niños de 8 a 12 años usados para el robo a residencias por organizaciones de adultos, especialmente celadores o vigilantes de edificios o conjuntos residenciales que preferían a los infantes para penetrar por ventanas o espacios reducidos. Pero no es la única modalidad. Los grupos de pares inventan sus propias formas en un aprendizaje y enseñanza continuos de los mayores a los de menos edad, muchas veces sin que los adultos perciban la fuente del dinero y las compras que manejan. 
El estudio cuantitativo más extenso realizado recientemente por el Gobierno de la ciudad de Bogotá señala:

[...] Entre las conductas punibles por las cuales se indagó, la de mayor prevalencia es el hurto: el $56 \%$ de los encuestados reportó haber sido víctima al menos una vez durante los 12 meses anteriores por hurto de elementos como útiles escolares, dinero, refrigerios, ropa, libros, balones, entre otros, sin haberlo advertido en el momento. [...]En cuanto a modalidades de hurto con violencia o amenaza de violencia, como sucede en el atraco, un $9 \%$ de los encuestados expresaron haber sido víctimas al menos una vez durante los pasados 12 meses de amenazas o agresiones sin armas para robarles algo: la prevalencia de este tipo de victimización entre la población masculina es mayor (11\%) que entre ellas (6\%). La encuesta también revela la ocurrencia de atracos con el uso de algún objeto a manera de arma: dentro del colegio durante los pasados 12 meses, el $3 \%$ de los encuestados fueron víctimas al menos una vez de este tipo de atracos. El fenómeno afecta de modo notorio a la población masculina (5\%), mientras que para el caso de ellas apenas alcanza a afectar al 1\%. [...](Observatorio de Convivencia y Seguridad Ciudadana. 2010, p. 41 y 42 ).

\section{Figura 9. Hurto con y sin violencia y vandalismo en entornos escolares}

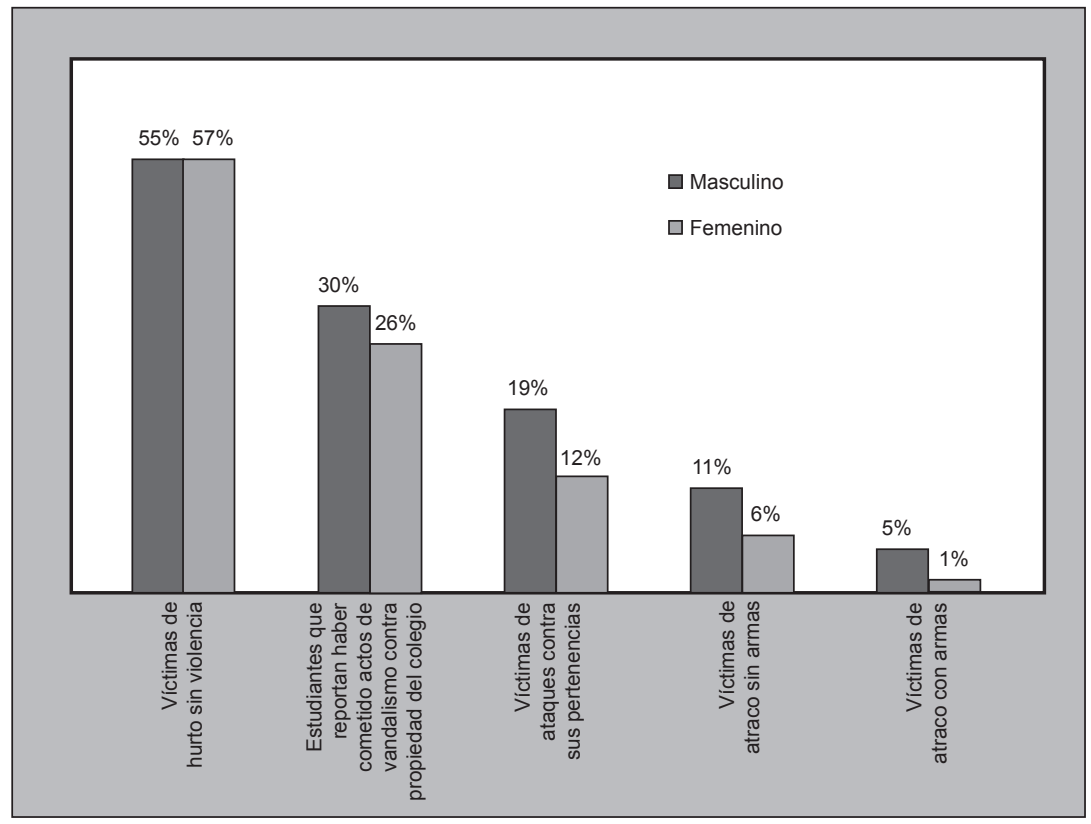

Fuente: SGD / DANE. Encuesta de Comportamientos y Actitudes escolares de $5^{\circ}$ a $11^{\circ}$ de Bogotá Tomado de: (Observatorio de Convivencia y Seguridad Ciudadana. 2010 p. 41). 
Luego el problema se expande a la ciudad, como el delito de mayor impacto social en Bogotá, porque se encuentra naturalizado y aceptado desde la escuela.

Figura 10. El Hurto en Bogotá 2004, 2007 y 2008

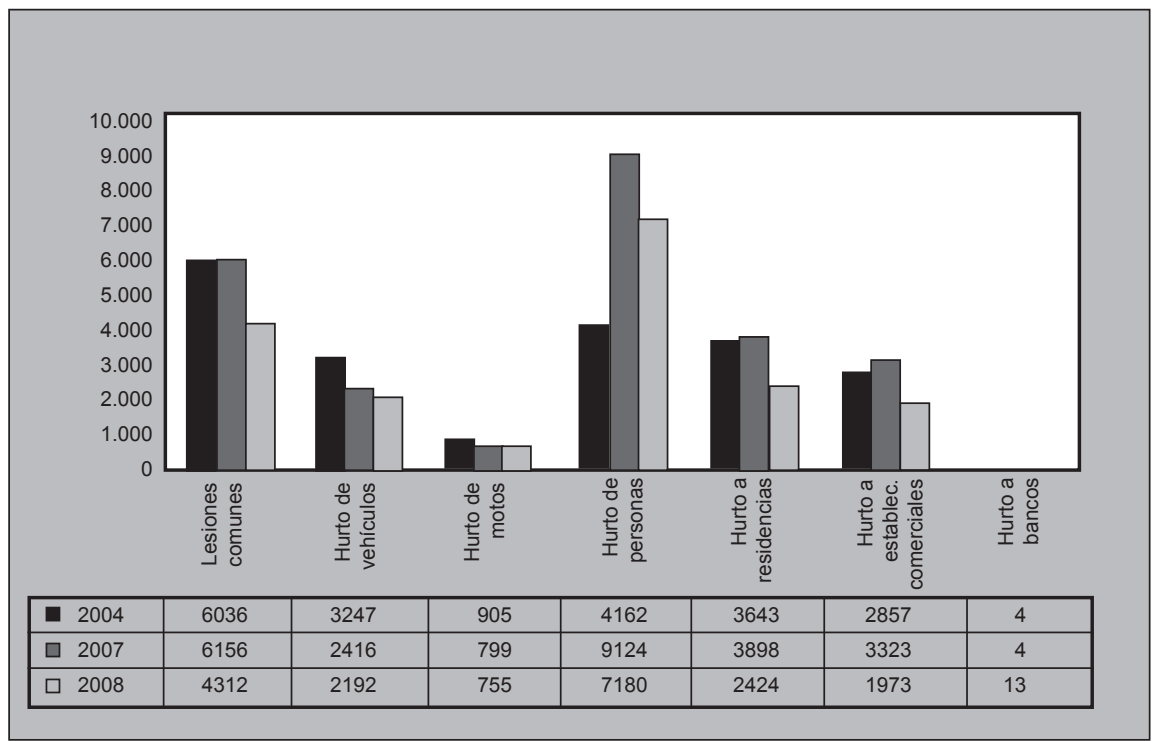

Fuente. Secretaría de Gobierno de Bogotá D.C., Observatorio de Convivencia y Seguridad Ciudadana, SUIVD Sistema Unificado de Información de Violencia y Delincuencia Bogotá D.C., 2007. Disponible en: <http://www.ceacsc.gov.co/index>

El estudio en mención, (Observatorio de Convivencia y Seguridad Ciudadana. 2010) señala como principales problemas la proliferación desmedida del hurto menor, el vandalismo, los insultos y maltratos físicos y verbales con intención de causar daño y una alta percepción de inseguridad en el camino al colegio, entre otras conductas y situaciones, pero todas ellas articuladas en un clima de inseguridad que es propicio para la presencia de otros factores de ilegalidad y transgresión.

Todos estos factores hacen que la escuela pública sea percibida por muchos padres, madres y jóvenes y por los líderes barriales, como espacio de socialización y difusión de riesgos sociales y violencias, situación que es el principal reto a transformar, labor que solo es posible con estrategias de diagnóstico oportuno, consensos de intervención por parte de padres y maestros, pero en general, elevando los niveles de conciencia y auto cuidado por parte de toda la comunidad educativa y barrial. 


\section{Conclusiones: Escuela, barrio y riesgo social}

1. La problemática asociada con la violencia en la Escuela y la comunidad barrial es muy variada pero identificable, Los problemas más comunes en la escuela y su entorno son el hurto menor, el vandalismo, las riñas y la inseguridad en el camino entre la vivienda y el colegio.

2. Los estudios recientes en Bogotá revelan que el hurto es la infracción predominante en las escuelas. Desde los primeros años se pasa del hurto oportunista, esporádico y casual, al hurto frecuente e intencionado que vincula al infante o adolescente con el mercado ilegal de objetos robados. Esta actividad es el puente más frecuente para que el niño o joven se vincule a sitios de venta de artículos usados. En generaciones anteriores, la actividad más usual era el hurto de ciertos textos escolares que tenían mercado asegurado en las librerías de usados que se ubicaban en el centro de la ciudad, luego se popularizó el mercado de otros objetos de valor como relojes, plumas o lapiceros de lujo, implementos de mayor valor como calculadoras electrónicas. Hoy el mercado ilegal más usual es el de teléfonos móviles o celulares, y artefactos digitales.

3. En el marco de este clima urbano general se insertan las organizaciones o estructuras de pares que fácilmente se articulan en la escuela pero interactúan en el barrio o vecindario y en la ciudad, que cuando se autonomizan, y para mantener sus consumos, convierten al pequeño hurto en el financiador de su autonomía del mundo de los adultos. Así, en las barriadas las mencionadas organizaciones de jóvenes o adolescentes se pueden transformar en "parches" o pandillas que hacen el tránsito a pequeñas estructuras "semiorganizadas" o "blandas" que fácilmente se mueven en la frontera de la legalidad o se transforman en organizaciones en "conflicto con la ley", lo que las hace fácilmente instrumentables por organizaciones "para el crimen" o por estructuras "duras" y permanentes del crimen organizado, como hemos dicho, iniciando el camino del deterioro social y de conflicto con la escuela, la familia y la propia comunidad barrial. 
4. En algunas localidades, encontramos un grave deterioro social y los oficios de muchos de los padres se ubicaban en la economía informal y en algunas ocasiones asociados a actividades delincuenciales como el pequeño robo, el atraco, el micro tráfico de estupefacientes, entre otros. Por ejemplo, vendedores ambulantes en los buses, como fachada, pero apoyados también en las actividades asociadas al robo. No obstante hay que señalar que la gran mayoría de los padres de familia se esfuerzan por una educación para que sus hijos sean "gente de bien" depositando en la educación las "esperanzas de un futuro mejor" para ellos.

5. La existencia de pequeños mercados de ilegalidad hace que estos también penetren a la escuela especialmente de dos formas: el pequeño robo de objetos de cada vez más valor comercial con la generalización del uso de teléfonos celulares y objetos electrónicos, principalmente, y los objetos de consumo tales como drogas, y sustancias volátiles, especialmente pegantes de bajo precio que se aspiran y producen efectos psicoactivos.

6. El barrio alrededor de las escuelas se vuelve el escenario de mercados y circuitos legales e ilegales que se vinculan alrededor de la institución educativa, que por su tamaño y complejidad en la ciudad posmoderna, se convierte en el espacio articulador de ellos, pero también de los conflictos que se desarrollan en su territorio tales como las tribus, las pandillas, los combos y las barras de futbol que se concentran alrededor de la escuela. Esta se transforma en la articuladora de todos estos fenómenos urbanos y fácilmente se crea el clima para que los intercambios se tornen violentos.

7. Hemos encontrado que alrededor de la escuela se dan los sitios y las prácticas que permiten que estos mercados y circuitos se realicen. En algunas tiendas de barrio muy cerca a las escuelas o en el centro de la ciudad, los jóvenes lo saben, se encuentran los sitios donde pueden vender a menosprecio los objetos que salen de sus crecientes conductas predatorias al interior de la escuela, o afuera de ella, para obtener el dinero con el que tempranamente pueden satisfacer sus deseos de todo tipo de consumos: desde la ropa de marca, las maquinitas tragamonedas, las sustancias adictivas o el alcohol, que cada vez son más frecuentes entre ellos.

8. Los padres, madres, maestros y líderes de las comunidades barriales pueden optar por un barrio capaz de contener a todos sin que los conflictos, normales y necesarios en toda comunidad humana se transformen en actos violentos, previniendo los ambientes que propician los escenarios indeseables que dan 
lugar a espacios para la delincuencia juvenil, las confrontaciones violentas y los excesos que dañan la convivencia. La presencia preventiva en parques, plazas y espacios comunitarios es uno de los caminos más efectivos para impedir que se transformen en territorios de nadie.

9. La familia, la escuela y el barrio, como comunidades dinámicas tienen la capacidad para interactuar preventivamente. Necesitan únicamente las herramientas adecuadas para que esta estrategia se construya. $Y$ el punto de partida proponemos que sea la escuela, porque ella en sí misma cuenta con la estructura y la capacidad de convocatoria y de acción con que otras instancias e instituciones no cuentan. Ella continúa ocupando un lugar central dentro de la comunidad.

10. En este contexto, consideramos que las violencias escolares y juveniles están inmersas en contextos sociales, económicos, políticos y planetarios. La metrópoli posmoderna es el teatro de todas las violencias. Unas están inmersas en dinámicas macro-sociales cuyos alcances escapan a la capacidad de prevención comunitaria. Pero no son las únicas y es posible que dichas violencias también estén inmersas en dinámicas micro-sociales, próximas a las comunidades, que son las que debemos privilegiar para la acción preventiva.

11. Escuela, familia y barrio son los espacios privilegiados para la estrategia de prevención de las violencias asociadas al mundo de niños y adolescentes, que están interconectadas con las culturas de los jóvenes del afuera de la institución escolar. La escuela debe romper el cerco de los riesgos que la rodean.

12.Para ello es necesario que la escuela y la familia acepten que el mundo de los jóvenes cambió. Que los adultos, incluidos padres y maestros no estamos preparados para los cambios que la infancia y la juventud han tenido en todos los aspectos en medio de una revolución cultural de carácter global. Que estamos viviendo un ciclo nuevo de las revoluciones de los jóvenes donde es cada vez más temprana la autonomización de los adolecentes. Y que si queremos transformar las situaciones de riesgo, tenemos el imperativo de comprender más y mejor esos cambios, respetar su autonomía como sujetos y colectivos, estigmatizar menos sus formas de vida y construir en común las soluciones. De lo contrario, como siempre ha sucedido, ellos se alejarán del mundo de sus mayores y cada vez contarán con más recursos y argumentos para construir su mundo asumiendo el costo y los riesgos en las luchas gene- 
racionales y el resultado puede ser el menos deseable para la familia, para la escuela y para la sociedad.

13. De las comunidades de padres y madres de familia, de maestros y estudiantes y líderes barriales, depende la construcción preventiva de las estrategias que puedan evitar el camino de las violencias con todas sus consecuencias. 
Alcaldía Mayor de Bogotá, Secretaría de Gobierno, Observatorio de Convivencia y Seguridad Ciudadana. (2006).Convivencia y Seguridad en ámbitos escolares de Bogotá. Recuperado el 1 de octubre de 2010 de: http://www.ceacsc.gov.co.

Barreto Nieto, Luis Hernando \& Rivera, Sneider. (2009) Una mirada a la impunidad en el marco del sistema penal oral acusatorio en Colombia. Recuperado el 8 abril de 2012 de: http://www.mij.gov.co/econtent/library/documents/DocNewsNo1813DocumentNo2779. PDF

Berger, Peter \& Luckmann, Thomas. (1999) La construcción social de la realidad. Buenos Aires: Amorrortu (Ed).

Bourdieu, Pierre \& Passeron, Jean. (2001). Fundamentos de una teoría de la violencia simbólica. En: La reproducción, elementos para una teoría del sistema de enseñanza, Libro 1, Editorial Popular, España.

Breman, J. (2003) The labouring poor. Patterns of exploitation, subordination, and exclusion. Delhi; Oxford, Oxford University Press.

Bogotá Cómo Vamos. (2005). Pobreza y distribución del ingreso en Bogotá. Proyecto Nacional de desarrollo humano, Recuperado el 20 de noviembre de 2011 de: http://www. fundacioncorona.org.co/descargas/publicaciones/gestion/GLC_48_PobreDistribucilngresoBogota.pdf.

Carvajalino, Hernando. (s.f.) La experiencia bogotana: del barrio obrero al lote con servicios. Revista Virtual Urbanismos. Recuperado el 13 enero de 2011 de: http://facartes. unal.edu.co/portal/publicaciones/urbanismos/urbanismos3/Experiencia_Bogotana_Barrio_Obrero_Lote.pdf.

Colón Llamas, Luis Carlos. (2007). El saneamiento del Paseo Bolívar y la vivienda obrera en Bogotá. En: Urbanismos $N^{\circ}$ 2: Colombia Universidad Nacional de Colombia, V (2), $119-128$

Colombia (19, noviembre, 1918) Ley 46. Por la cual se dicta una medida de salubridad pública y se provee a la existencia de habitaciones higiénicas para la clase proletaria. Recuperado el 20 de diciembre de 2011 de: http://camacol.co/estudios_juridicos/Archivos/ LEY_CONGRESO_NACION_0046_1918.html

Colombia (26, diciembre, 1924). Ley 68. Sobre fundación de un Banco Agrícola Hipotecario. Recuperado el 15 de octubre de 2011 de: http://www.colombialink.com/01_INDEX/ index_historia/07_otros_hechos_historicos/0160_nace_banca_central.html

Colombia (6, abril, 1967). Decreto 606. Sobre la creación de la Dirección Nacional de la Defensa Civil, bajo dependencia y orientación de la Presidencia de la República, en el marco de las políticas de la "guerra Fría". Recuperado el 3 de noviembre de 2011 de: http://cidbimena.desastres.hn/pdf/spa/doc1158/doc1158-6.pdf

Colombia (16, julio, 1996). Ley 294 de 1996. Por la cual se desarrolla el artículo 42 de la Constitución Política y se dictan normas para prevenir, remediar y sancionar la violencia 
intrafamiliar. Diario oficial, 44837. Recuperado 5 enero de 2011 de: http://www.alcaldiabogota.gov.co/sisjur/normas/Norma1.jsp?i=5387

Colombia (11, febrero, 2000). Ley 575. Por medio de la cual se reforma parcialmente la Ley 294 de 1996. Diario Oficial, 43.889. Recuperado el 10 de diciembre de 2011 de: http://www.secretariasenado.gov.co/senado/basedoc/ley/2000/ley_0575_2000.html

Colombia (25, julio, 2005). Ley 975 . Por la cual se dictan disposiciones para la reincorporación de miembros de grupos armados organizados al margen de la ley, que contribuyan de manera efectiva a la consecución de la paz nacional y se dictan otras disposiciones para acuerdos humanitarios. Diario Oficial. 45.980. Recuperado el 10 de mayo de 2011 de: http://www.secretariasenado.gov.co/senado/basedoc/ley/2005/ley_0975_2005.html

Colombia Tasa de desempleo. Recuperado el 13 de julio de 2011 de: http://www.indexmundi.com/es/colombia/tasa_de_desempleo.html

Dammert, Lucía. (2004). Reseña de "la ciudad conquistada" de Jordi Borja. Revista Latinoamericana de Estudios Urbano Regionales. V (30), 90. Recuperado el 18 de mayo de 2011 de: http://redalyc.uaemex.mx/pdf/196/19609009.pdf

Davis, Mike. (2008). Planeta de ciudades miseria. Madrid: Foca/Universidad Nómada.

De Certeau, Michael; Giard, Luce \& Mayol, Pierre. (1999). La invención de lo cotidiano 2. Habitar, cocinar. México: Universidad Iberoamericana, Instituto Tecnológico y de Estudios Superiores de Occidente.

Díaz Cotrino, Y. (2006). La intervención del Estado en la vivienda obrera en Bogotá 19181942 Colombia, 2006, Maestría En Historia, Universidad Pedagógica Y Tecnológica De Colombia - UPTC - Sede Tunja.

Díaz Cotrino, Y. (2007). La vivienda obrera. ¿un elemento apaciguador o modernizador? La intervención del Estado en Bogotá 1918-1942. Revista de Arquitectura, 5-12.

Durkheim, Emile. (1982). La división del trabajo social. Traducido por Carlos Posada. Madrid: Akal (Ed.)

Elias, Norbert. (1986). El proceso de la civilización: Investigaciones sociogenéticas y psicogenéticas. México: Fondo de Cultura Económica.

Equipo Interdisciplinario Sobre Impunidad y Memoria. (2010). Memoria de la impunidad en Antioquia. Lo que la justicia no quiso ver frente al paramilitarismo. Colombia: Instituto popular de capacitación, Corporación Jurídica Libertad.

Fernández, J. Manuel. (2005). La noción de violencia simbólica en la obra de Pierre Bourdieu: una aproximación crítica. En: Cuadernos de trabajo social. (Vol. 18).

Fundación de Atención al Migrante de la Arquidiócesis de Bogotá (FAMIG) y Consultoría para los Derechos Humanos y el Desplazamiento (Codhes). (2007). Rojas, J. Gota a gota: el desplazamiento en Bogotá y Soacha. Bogotá: FAMIG y CODHES. p. 149

Galtung, Johan. (2003). Tras la violencia, 3R: reconstrucción, reconciliación, resolución. Afrontando los efectos visibles e invisibles de la guerra y la violencia. Bilbao, España: Bakeaz y Gernika Gogoratuz (Colección Red Gernika. 6)

García Sánchez, Bárbara Yadira. (2003). Los Núcleos de Educación Familiar: Investigación participativa para prevenir violencias difusas en escuela, familia y barrio. Tesis de maestría no publicada. Bogotá, D. C., Universidad Nacional de Colombia. Bogotá, Colombia.

García Sánchez, Bárbara Yadira. (2008, julio-diciembre). Familia, Escuela y Barrio: Un Contexto para la Comprensión de la Violencia Escolar. En: Revista Colombiana de Educación. no. 55. p. 108-124. 
Guerrero Barón, Javier \& García Sánchez, Bárbara Yadira. (2009). Las ciencias sociales y la invención del tercer mundo: A propósito de la obra académica de Orlando Fals Borda (I). Revista Historia de la Educación Latinoamericana. V. (12), 42-31.

Guerrero Barón, Javier \&. García Sánchez, Bárbara Yadira. (2011). Nuevas concepciones de autoridad y cambios en las relaciones de violencia en la familia y la escuela. Magis, Revista Internacional de Investigación en Educación, 4 (8) Edición especial La violencia en las escuelas, 297-318.

Guerrero Barón, Javier \&. García Sánchez, Bárbara Yadira. (2012). Violencia, crisis del capitalismo global y jóvenes. Revista Colombiana de Educación, 62.

Gutiérrez, Alicia. (2004). "Poder, hábitus y representaciones: recorrido por el concepto de violencia simbólica en Pierre Bourdieu”. Revista Complutense de Educación, V. (15), 1.

Instituto Nacional de Medicina Legal y Ciencias Forenses. (1999). Documento del Centro de Referencia Nacional sobre Violencia. Bogotá. Sección de Divulgación, información científica.

Instituto Nacional de Medicina Legal y Ciencias Forenses. (2005). Revista Forensis. Datos para la vida. Bogotá, D. C. Imprelibros S.A. (Ed.) 2006.

Instituto Nacional de Medicina Legal y Ciencias Forenses. (2006). Revista Forensis. Datos para la vida. Bogotá, D. C. Montes S.A. (Ed.) 2007.

Instituto Nacional de Medicina Legal y Ciencias Forenses. (2007). Revista Forensis. Datos para la vida. Bogotá, D. C. International Print Ltda. (Ed.) 2008.

Instituto Nacional de Medicina Legal y Ciencias Forenses. (2008). Revista Forensis. Datos para la vida. Bogotá, D. C.: Quebecor. (Ed.) 2009.

Iriarte, Joxe. Sobre el fin de ETA y la refundación de... Blog Revista Rebelión. Recuperado el 6 enero de 2011 de: http://www.rebelion.org/noticia.php?id=117715.

Jaramillo, Jaime Eduardo. (1996). El campo Urbano-Popular: Poblamiento, espacio público, organizaciones dinamizadoras, tiempo libre. Bogotá: Universidad Nacional de Colombia.

Jimeno, Myriam et al. (2007). Manes, mansitos y manazos: Una metodología de trabajo sobre violencia intrafamiliar y sexual. Colombia: Centro de Estudios Sociales. Facultad de Ciencias Humanas. Universidad Nacional de Colombia.

Keane, Jhon. (2000). Reflexiones sobre la violencia. Madrid: Alianza Editorial.

Kliksberg, Bernardo. (2009, 24 de junio). América Latina: alto riesgo social. El país. Madrid: Recuperado el 11 de agosto de 2011 de: http://www.elpais.com/articulo/opinion/ America/Latina/alto/riesgo/social/elpepuint/20090624elpepiopi_13/Tes.

Laquian, A. (1977). Lotes con servicios, solución a tugurios e invasiones. Recuperado el 15 de diciembre de 2011 de. http://idl-bnc.idrc.ca/dspace/bitstream/10625/25229/1/109763. pdf

Llorente, María Victoria et. al. (2000). Violencia homicida y estructuras criminales en Bogotá. Bogotá: Universidad de los Andes.

Marcial, Rogelio. (1995, enero-marzo). Entre el Aula y la Esquina. La tarea, Revista de Educación y cultura de la sección 47 del SNTE. Recuperado el 25 octubre de 2010 de: http://www.latarea.com.mx/indices/indice6.htm. 
Merton, Robert K. (1980). Teoría y estructura sociales. México: Fondo de Cultura Económica.

Mesa, Manuela. (2006). Violencia social y globalización en América Latina. Madrid: Centro de investigaciones para la paz, Fundación Carolina.

Monsiváis, Carlos. (1999, Mayo). Notas sobre Violencia Urbana. Revista digital letras libres.com. 5. Recuperado el 25 de septiembre de 2010 de: http://www.letraslibres.com/ index.php?art=5795.

Mozzo, Enrique. (2001, Julio). Capitalismo hoy: La nueva marginalidad. Acerca del libro Parias Urbanos. Marginalidad en la ciudad a comienzos del milenio, de Loic Wacquant. Revista Herramienta. 16. Recuperado el 5 de enero 2011 de: http://www.herramienta. com.ar/revista-herramienta-n-16/capitalismo-hoy-la-nueva-marginalidad-acerca-del-libroparias-de-la-ciudadm

OIT. (2010). Panorama Laboral. Oficina Regional para América Latina y el Caribe (OIT). Lima: Recuperado 13 Julio de 2011, de: http://oit.org.pe/WDMS/bib/publ/panorama/panorama10.pdf

Organización Mundial de la Salud. (2003). Informe mundial de violencia y de la salud. Washington, D. C.: Organización Panamericana de la Salud, Organización Mundial de la Salud.

Ortiz, Carlos Miguel. (1985). Estado y subversión en Colombia, La violencia en el Quindío en los años 50. Bogotá, CEREC.

Paras: a paso grande. (2004, 25 de Septiembre). El Tiempo. Bogotá, Recuperado el 14 de octubre de 2011 de: http://www.eltiempo.com/archivo/documento/MAM-1526705

Parra Sandoval, Rodrigo et. al. (1996). La Escuela Urbana. Bogotá: Tercer Mundo Editores.

Pinilla, María del Carmen. (2009). Transformaciones y cambios percibidos por las mujeres a partir del desplazamiento, con relación a ellas mismas, y sus familias, y prácticas alternativas para responder a la subsistencia y la integración social. Tesis de maestría. Universidad Javeriana. Bogotá, Colombia.

PROFAMILIA. (2004). Encuesta de Demografía y salud. Bogotá, Colombia.

Rivera, Sneider \& Barreto, Luis. Resumen ejecutivo La impunidad en el sistema penal acusatorio en Colombia. Recuperado el 7 enero de 2011 de: http://www.mij.gov.co/econtent/library/documents/DocNewsNo4362DocumentNo2463.PDF

Rodó, José Enrique. (1993). Motivos de Proteo. Caracas: Ángel Rama, ed.

Rubiano, Norma. (2003). Conflicto y violencia intrafamiliar. Bogotá: Sigma Editores.

Sánchez, Gonzalo. (1985). Once ensayos sobre la Violencia. Bogotá: Fondo Editorial CEREC.

Sánchez Vásquez, Adolfo. (1998). El mundo de la violencia. México, Editorial Fondo de Cultura Económica.

Saldarriaga, Alberto. (2000). Bogotá siglo XX, urbanismo, arquitectura y vida urbana. Bogotá: Departamento Administrativo de Planeación Distrital.

Wacquant, Loïc (2001). Parias urbanos, marginalidad en la ciudad a comienzos del milenio. Buenos Aires: Manantial. 

Este libro se publicó en Bogotá, Colombia, en el año 2012, con la dirección gráfica de Común Presencia Editores. 